Prepared in cooperation with the City of Independence, Missouri

\title{
Water-Quality Changes Caused by Riverbank Filtration Between the Missouri River and Three Pumping Wells of the Independence, Missouri, Well Field, 2003-05
}

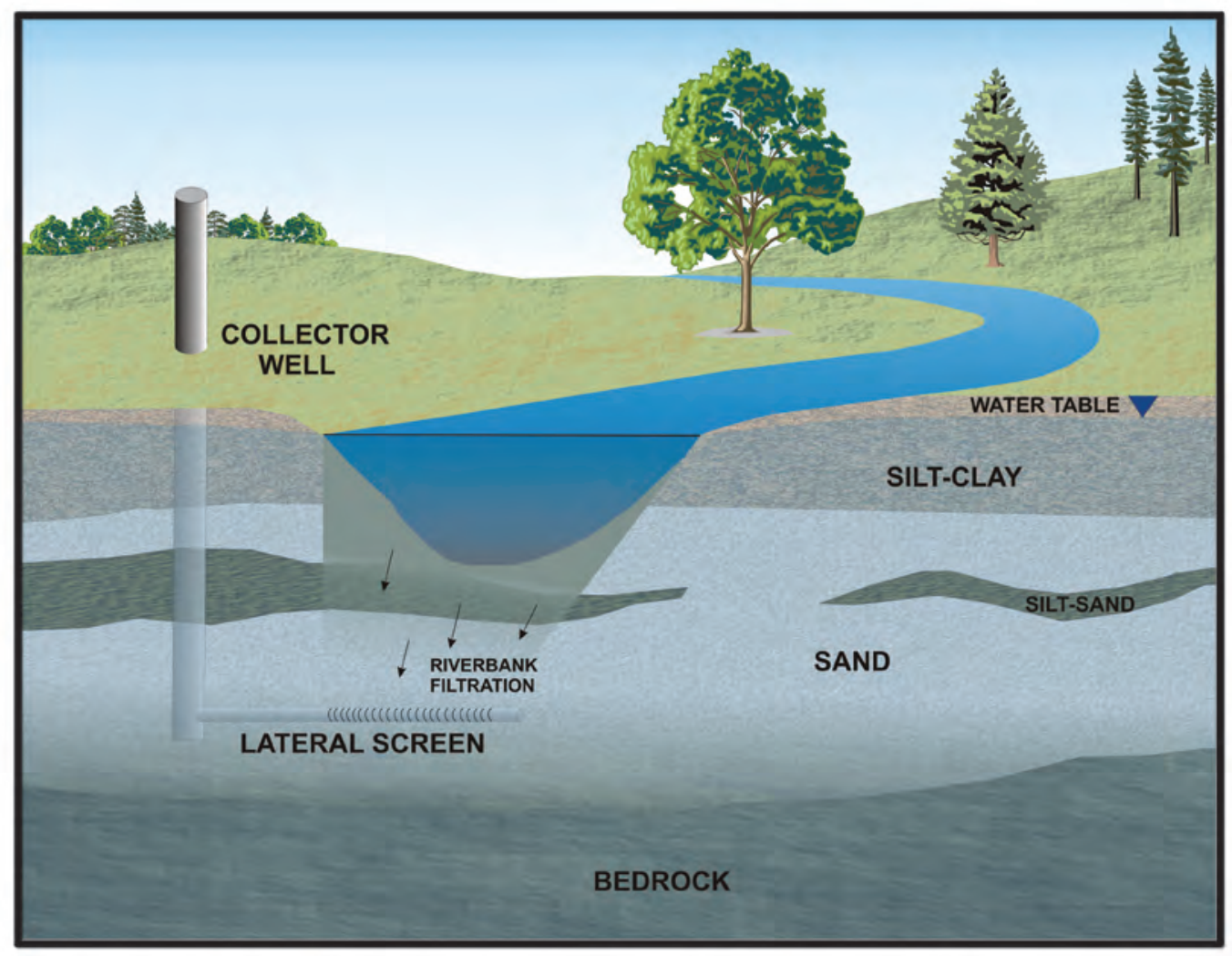

Scientific Investigations Report 2006-5174 


\section{Water-Quality Changes Caused by Riverbank Filtration Between the Missouri River and Three Pumping Wells of the Independence, Missouri, Well Field 2003-05}

By Brian P. Kelly and Paul H. Rydlund, Jr.

Prepared in cooperation with the

City of Independence, Missouri

Scientific Investigations Report 2006-5174 


\title{
U.S. Department of the Interior DIRK KEMPTHORNE, Secretary
}

\author{
U.S. Geological Survey \\ P. Patrick Leahy, Acting Director
}

\section{U.S. Geological Survey, Reston, Virginia: 2006}

For sale by U.S. Geological Survey, Information Services

Box 25286, Denver Federal Center

Denver, CO 80225

For more information about the USGS and its products:

Telephone: 1-888-ASK-USGS

World Wide Web: http://www.usgs.gov/

Any use of trade, product, or firm names in this publication is for descriptive purposes only and does not imply endorsement by the U.S. Government.

Although this report is in the public domain, permission must be secured from the individual copyright owners to reproduce any copyrighted materials contained within this report. 


\section{CONTENTS}

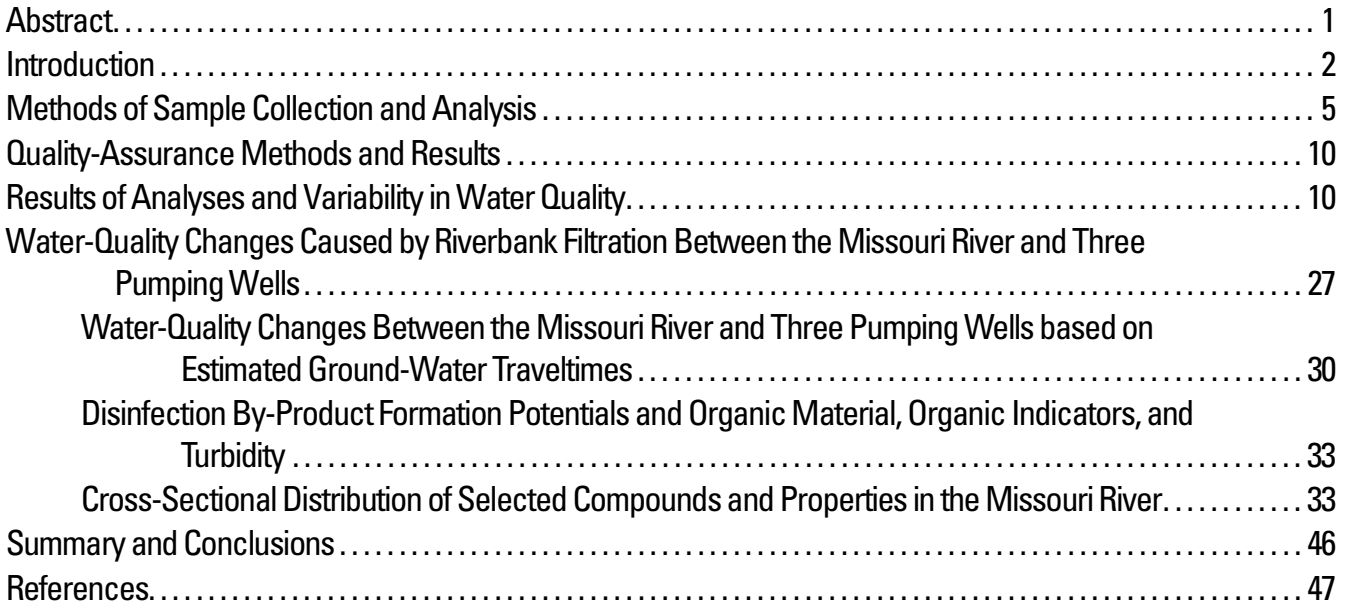

\section{Figures}

1-2. Maps showing:

1. Location of the Independence well field .3

2. Inflows to the Missouri River that may affect river-water quality near the Independence

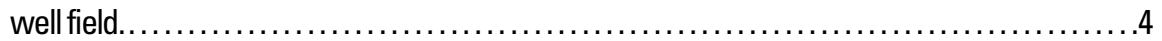

3. Generalized geologic section A-A' near collector well 41 of the Independence well field ..........5

4. Graph showing Missouri River sampling dates and discharge at Kansas City, Missouri, October 29, 2003, through August 31, 2004.

5. Box plots showing statistical summary of dissolved oxygen concentrations and selected physical properties in water samples from the Missouri River, wells 7 and 38, and collector

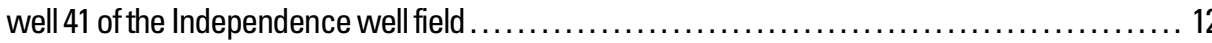

6. Graphs showing dissolved oxygen concentrations and values of physical properties in water samples from the Missouri River, wells 7 and 38, and collector well 41 with time, and in water samples from the Missouri River with discharge.

7. Box plots showing statistical summary of organic material and organic indicators in water samples from the Missouri River, wells 7 and 38, and collector well 41 of the Independence

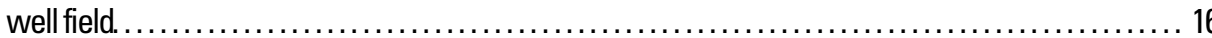

8. Graphs showing organic material concentrations and values of organic indicators in water samples from the Missouri River, wells 7 and 38, and collector well 41 with time, and in water samples from the Missouri River with discharge.

9. Box plots showing statistical summary of selected nutrients in water samples from the Missouri River, wells 7 and 38, and collector well 41 of the Independence well field.

10. Graphs showing nutrient concentrations in water samples from the Missouri River, wells 7 and 38, and collector well 41 with time, and in water samples from the Missouri River with discharge.... 20

11. Box plots showing statistical summary of total coliform bacteria and total culturable viruses in water samples from the Missouri River, wells 7 and 38, and collector well 41 of the Independence well field. ....

12. Graphs showing total coliform bacteria, Giardia, and total culturable viruses in water samples from the Missouri River with time and discharge. 
13. Box plots showing statistical summary of haloacetic acid formation potentials in six water samples from the Missouri River, wells 7 and 38, and collector well 41 of the Independence well field. ....

14. Graphs showing haloacetic acid formation potential concentrations in water samples from the Missouri River, wells 7 and 38, and collector well 41 with time, and in water samples from the Missouri River with discharge.

15. Box plots showing statistical summary of trihalomethane formation potential concentrations in six water samples from the Missouri River, wells 7 and 38, and collector well 41 of the Independence well field.

16-20. Graphs showing:

16. Trihalomethane formation potential concentrations in water samples from the Missouri River, wells 7 and 38, and collector well 41 with time, and in water samples from the Missouri River with discharge ....

17. Median log removals of turbidity, total coliform bacteria, Cryptosporidium, Giardia, and total culturable viruses calculated using the minimum reporting level, one-half the minimum reporting level, and one-tenth the minimum reporting level between water samples from the Missouri River and water samples from wells.

18. Minimum log removals of turbidity, total coliform bacteria, Giardia, and total culturable viruses in water samples from all wells based on ground-water traveltime between the Missouri River and wells.

19. Organic material, organic indicators, turbidity, and total haloacetic acid formation potential in water samples from the Missouri River and all wells

20. Organic material, organic indicators, turbidity, and total trihalomethane formation potential in water samples from the Missouri River and all wells ....

21-24. Maps showing:

21. Dissolved oxygen concentration in the Missouri River near the Independence well field, August 2005 ....

22. Specific conductance values in the Missouri River near the Independence well field, August 2005

23. Water temperature in the Missouri River near the Independence well field, August 2005 ....

24. Turbidity values in the Missouri River near the Independence well field, August 2005 


\section{Tables}

1. Dissolved oxygen, physical properties, organic material, organic indicators, nutrients, total coliform bacteria, Cryptosporidium, Giardia, total culturable viruses, haloacetic acid formation potentials, trihalomethane formation potentials, and organic wastewater compounds

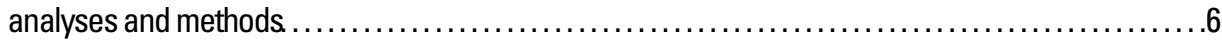

2. Sampling schedule and analyses for each water sample ...............................

3. Quality-assurance/quality-control sample results for water samples from the Missouri River,

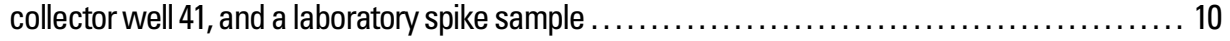

4. Missouri River discharge, dissolved oxygen, and physical properties in water samples from the

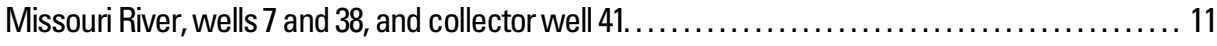

5. Organic material and organic indicators in water samples from the Missouri River, wells 7

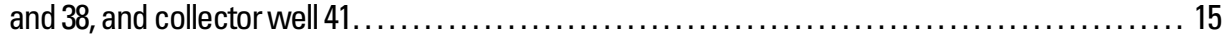

6. Nutrients in water samples from the Missouri River, wells 7 and 38 , and collector well $41 \ldots \ldots \ldots 18$

7. Total coliform bacteria, Cryptosporidium, Giardia, and total culturable viruses in water

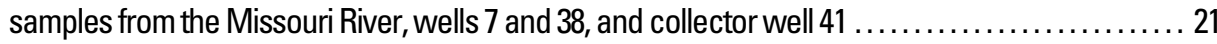

8. Haloacetic acid formation potentials in water samples from the Missouri River, wells 7 and 38,

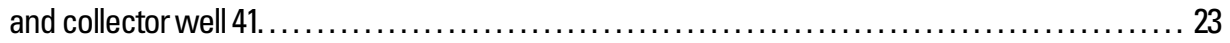

9. Trihalomethane formation potentials in water samples from the Missouri River, wells 7 and 38,

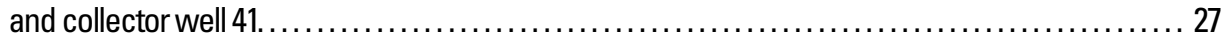

10. Median values and change in median values of water quality in water samples between the Missouri River, wells 7 and 38 , collector well 41, and all wells ........................... 31

11. Well depths, screened intervals, and distance from the Missouri River to screened intervals of

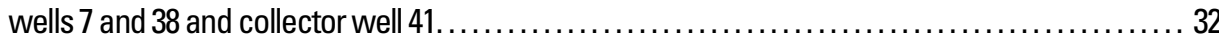

12. Water quality of samples from the Missouri River and samples collected at times that approximated the traveltime from the Missouri River to wells 7 and 38 and collector well $41 \ldots \ldots 34$

13. Dissolved organic wastewater compounds detected in water samples from the Missouri River, wells 7 and 38 , and collector well 41 


\section{Conversion Factors and Datum}

\begin{tabular}{lcl}
\hline Multiply & By & To obtain \\
\hline & Length & \\
\hline inch (in.) & 2.54 & centimeter $(\mathrm{cm})$ \\
inch (in.) & 25.4 & millimeter $(\mathrm{mm})$ \\
foot (ft) & 0.3048 & meter $(\mathrm{m})$ \\
mile (mi) & 1.609 & kilometer $(\mathrm{km})$ \\
& & \\
\hline & Flow rate & \\
\hline & & \\
foot per day (ft/d) & 0.3048 & meter per day $(\mathrm{m} / \mathrm{d})$ \\
cubic foot per second $\left(\mathrm{ft}^{3} / \mathrm{s}\right)$ & 0.02832 & cubic meter per second $\left(\mathrm{m}^{3} / \mathrm{s}\right)$ \\
million gallons per day $(\mathrm{Mgal} / \mathrm{d})$ & 0.04381 & cubic meter per second $\left(\mathrm{m}^{3} / \mathrm{s}\right)$ \\
& & \\
\hline
\end{tabular}

\section{Conversion Factors and Datum}

\begin{tabular}{lcl}
\hline Multiply & By & To obtain \\
\hline \multicolumn{3}{c}{ Length } \\
millimeter (mm) & 0.03937 & inch (in.) \\
& & \\
\hline \multicolumn{3}{l}{ Volume } \\
liter (L) & 33.82 & ounce, fluid (fl. oz) \\
liter (L) & 2.113 & pint (pt) \\
liter (L) & 1.057 & quart (qt) \\
liter (L) & 0.2642 & gallon (gal) \\
liter (L) & 61.02 & cubic inch (in $\left.{ }^{3}\right)$ \\
& & \\
\hline
\end{tabular}

Temperature in degrees Celsius $\left({ }^{\circ} \mathrm{C}\right)$ may be converted to degrees Fahrenheit $\left({ }^{\circ} \mathrm{F}\right)$ as follows:

$$
{ }^{\circ} \mathrm{F}=\left(1.8 \mathrm{x}^{\circ} \mathrm{C}\right)+32
$$

Altitude, as used in this report, refers to distance above the National Geodetic Vertical Datum of 1988 (NGVD88) - A geodetic datum derived from a general adjustment of the first-order level nets of both the United States and Canada.

Horizontal coordinate information is referenced to the North American Datum of 1983 (NAD83).

Specific conductance is given in microsiemens per centimeter at 25 degrees Celsius $(\mu \mathrm{S} / \mathrm{cm}$ at $\left.25^{\circ} \mathrm{C}\right)$.

Concentrations of chemical constituents in water are given either in milligrams per liter (mg/L) or micrograms per liter $(\mu \mathrm{g} / \mathrm{L})$. 


\title{
Water-Quality Changes Caused by Riverbank Filtration Between the Missouri River and Three Pumping Wells of the Independence, Missouri, Well Field 2003-05
}

\author{
By Brian P. Kelly and Paul H. Rydlund, Jr.
}

\section{Abstract}

The city of Independence, Missouri, operates a well field in the Missouri River alluvial aquifer. About 250,000 people in several communities were supplied water from the 29 million gallons per day average daily production from the well field in 2004. In 2005, the Independence Water Department followed source-water treatment rules established by the State of Missouri for ground water that include maximum contaminant levels for disinfection by-products, minimum residual disinfectant levels in finished water, and specific goals for removal and (or) inactivation of bacteria, protozoa, and viruses.

Study results indicate riverbank filtration substantially improves the source-water quality of the Independence well field. Samples analyzed from the Missouri River near the Independence well field, two vertical wells, and a collector well indicate riverbank filtration decreased dissolved oxygen, $\mathrm{pH}$, turbidity, dissolved organic carbon, ultraviolet absorption at 254 nanometers, chlorophyll $a$, tannin and lignin, and dissolved ammonia nitrogen in two wells. Dissolved nitrite nitrogen, dissolved nitrate nitrogen, dissolved orthophosphorous, total coliform bacteria, Cryptosporidium, Giardia, total culturable viruses, total haloacetic acid formation, and total trihalomethane formation potential decreased between the Missouri River and three wells of the Independence well field.

Total coliform bacteria, Cryptosporidium, Giardia, and total culturable viruses were detected in the Missouri River, but were below minimum reporting levels in all samples from wells. Total coliform bacteria decreased 100 percent, Cryptosporidium decreased between 96 and 100 percent, Giardia decreased between 97 and 100 percent, and total culturable viruses decreased between 85 and 100 percent between the Missouri River and wells, using minimum reporting levels for non-detections in water samples. Log removals between the Missouri River and wells were greater than 1.60 for turbidity, greater than 4.57 for total coliform bacteria, greater than 1.67 for Cryptosporidium, greater than 1.67 for Giardia, and greater than 1.15 for total culturable virus.

Approximate ground-water traveltimes from the river to the wells based on water temperature profiles ranged from 1 to 9 months. The rate of ground-water flow from the Missouri River to the wells ranged between 1.2 and 6.7 feet per day.
These rates are less than rates typical of slow sand filters. Slower flow rates result in greater filtration and indicate riverbank filtration at this site may be comparable to or more effective than a slow sand filter.

Water-quality changes between samples from the Missouri River and samples collected from wells at times that approximated the traveltime from the Missouri River to wells indicate no clear relation between changes in water quality in the Missouri River and in wells for almost all constituents. The absence of any trends in water quality between the Missouri River and the pumping wells indicates the strong influence of riverbank filtration.

Minimum log removals were calculated between samples from the Missouri River and wells based on ground-water traveltime and were infinite for total coliform bacteria, and range from 0.8 to 3.5 for turbidity, from 1.5 to 2.1 for Giardia, and from 0.4 to 2.6 for total culturable viruses. Log removals for Cryptosporidium were not included because it was detected only once at the end of the sampling period and no corresponding well samples were collected.

For water samples from the Missouri River, haloacetic acid formation potential was related positively to ultraviolet absorption at 254 nanometers $\left(\mathrm{R}^{2}=0.94\right)$, tannin and lignin $\left(\mathrm{R}^{2}\right.$ $=0.93)$, and turbidity $\left(R^{2}=0.97\right)$, and trihalomethane formation potential was related positively to dissolved organic carbon $\left(\mathrm{R}^{2}\right.$ $=0.89)$, ultraviolet absorption at 254 nanometers $\left(R^{2}=0.85\right)$, tannin and lignin $\left(R^{2}=0.90\right)$, and turbidity $\left(R^{2}=0.89\right)$. These would likely be good indicators of haloacetic acid and trihalomethane formation potentials in water from the Missouri River. Haloacetic acid formation potential and trihalomethane formation potential were not well related to any of these organic materials, organic indicators, or turbidity for water samples from wells.

Organic wastewater compounds were detected in samples collected from a cross section of the Missouri River and all sampled wells. Synoptic measurements of dissolved oxygen, specific conductance, temperature, and turbidity in the Missouri River adjacent to the Independence well field were used to create maps of their distribution in the river. Results of analyses for organic wastewater compounds and the distribution of dissolved oxygen, specific conductance, and temperature indicate that Missouri River water quality on the south side of the river 


\section{Water-Quality Changes Caused by Riverbank Filtration Between the Missouri River and Three Pumping Wells}

was moderately influenced by the south bank inflows to the river just upstream from the Independence well field.

\section{Introduction}

The city of Independence, Missouri, operates a well field in the Missouri River alluvial aquifer (fig. 1). About 250,000 people in several communities were supplied water from the 29 million gallons per day average daily production from the well field in 2004 (Independence Water Department, written commun., 2004). Previous studies by the U.S. Geological Survey (USGS) have characterized the hydrogeology of, and groundwater flow in, the Missouri River alluvial aquifer and contributing recharge areas in the Kansas City metropolitan area to public-water-supply well fields including the Independence well field (Kelly and Blevins, 1995; Kelly, 1996).

The results of a study determining the relative amounts of Independence well field pumpage derived from ground water and the amount of induced inflow from the Missouri River indicate that approximately 50 to 90 percent of the pumpage from the Independence well field is induced from the Missouri River (Kelly, 2002). Consequently, the quality of the river water affects the quality of the pumped water.

Inflows to the Missouri River that may affect river-water quality near the Independence well field include direct discharges from sewage-treatment plants and chemical manufacturers, and possible runoff or ground-water seepage from a former oil refinery, or the Conservation Chemical Superfund site (U.S. Environmental Protection Agency, 2005). Industrial discharges to the Blue River, a tributary to the Missouri River just upstream from the Independence well field, also may affect water quality (fig. 2). If water quality of the Missouri River substantially is affected by water from urban point sources, then the quality of source water to the Independence well field also may be affected.

In 2005, the Independence Water Department followed source-water treatment rules established for ground water by the State of Missouri (Missouri Department of Natural Resources, 2003); however, given the close connection between some wells and the Missouri River, the treatment strategy may need to change to comply with rules established for ground water under the direct influence of surface water. These rules include maximum contaminant levels (MCLs) of disinfection by-products, minimum residual disinfectant levels (MRDLs) in finished water, and specific goals for removal and (or) inactivation of bacteria, protozoa (Giardia and Cryptosporidium), and viruses.

Disinfectants used in water-treatment systems to control harmful microorganisms can combine with naturally occurring organic and inorganic matter to form potentially harmful disinfection by-products. Some disinfection by-products can cause cancer and reproductive or developmental effects in laboratory animals (Nikolaou and others, 1999). Examples of chlorinated, organic disinfection by-products include haloacetic acids and trihalomethanes. Simultaneously removing or inactivating microorganisms using disinfectants, maintaining MRDLs in the water system, and limiting the formation of disinfection byproducts in finished water is a challenge faced by public-water suppliers across the nation. Several methods to reduce the formation of disinfection by-products are available to water suppliers. These include treating water to remove disinfection byproducts after their formation, using alternative disinfectants that do not promote the formation of disinfection by-products, and removing disinfection by-product precursors before disinfectants are added (Nikolaou and others, 1999). In many cases, removing disinfection by-products after formation is not economical, and alternative disinfectants (sometimes less effective than the widely used chlorine in removing bacteria, protozoa, and viruses) also may form disinfection by-products; therefore, removing disinfection by-product precursors before adding disinfectant may be the most viable method of limiting disinfection by-product formation for many drinking-water suppliers.

Methods to remove disinfection by-product precursors from source water include coagulation, softening, membrane filtration, or absorption onto granular activated carbon. For public-water suppliers like the Independence Water Department, with source water that may be ground water under the direct influence of surface water, riverbank filtration can be used to improve source-water quality before the addition of disinfectant. Riverbank filtration is the filtering of river water intended for public-water supply through alluvial deposits using infiltration galleries, pumping wells located near rivers, or horizontal collector wells located beneath rivers. Riverbank filtration can remove varying quantities of herbicides, herbicide metabolites, organics, microbes, and particulates from surface water. Processes that occur during riverbank filtration include mechanical filtration, adsorption, biodegradation, ion exchange, and chemical reactions (Wang and others, 2002). Important constituents potentially removed from source water by riverbank filtration are parasites, bacteria, viruses, and organic matter, a precursor of disinfection by-products. Removal goals typically are expressed in terms of log removal where $1 \log$ removal removes 90 percent, 2 log removal removes 99 percent, and 3 log removal removes 99.9 percent, and so on.

Knowledge of the change in water quality caused by riverbank filtration between the Missouri River and the wells of the Independence well field can be used to indicate the most effective types of water treatment for the city of Independence Water Plant and other similar public-water supplies. Reducing disinfection by-product precursor material and inactivating bacteria, protozoa, and viruses from riverbank filtration can limit the formation of disinfection by-products because less precursor material is available and less disinfectant is required. Quantification of the removal of these constituents allows managers to alter well field operations to enhance precursor and microbial removal. However, improvement of the quality of source water to the Independence well field from riverbank filtration was unknown before this study. Numerous water supplies across the nation are designated as ground water under the direct influence of surface water. Information about removing disinfection 


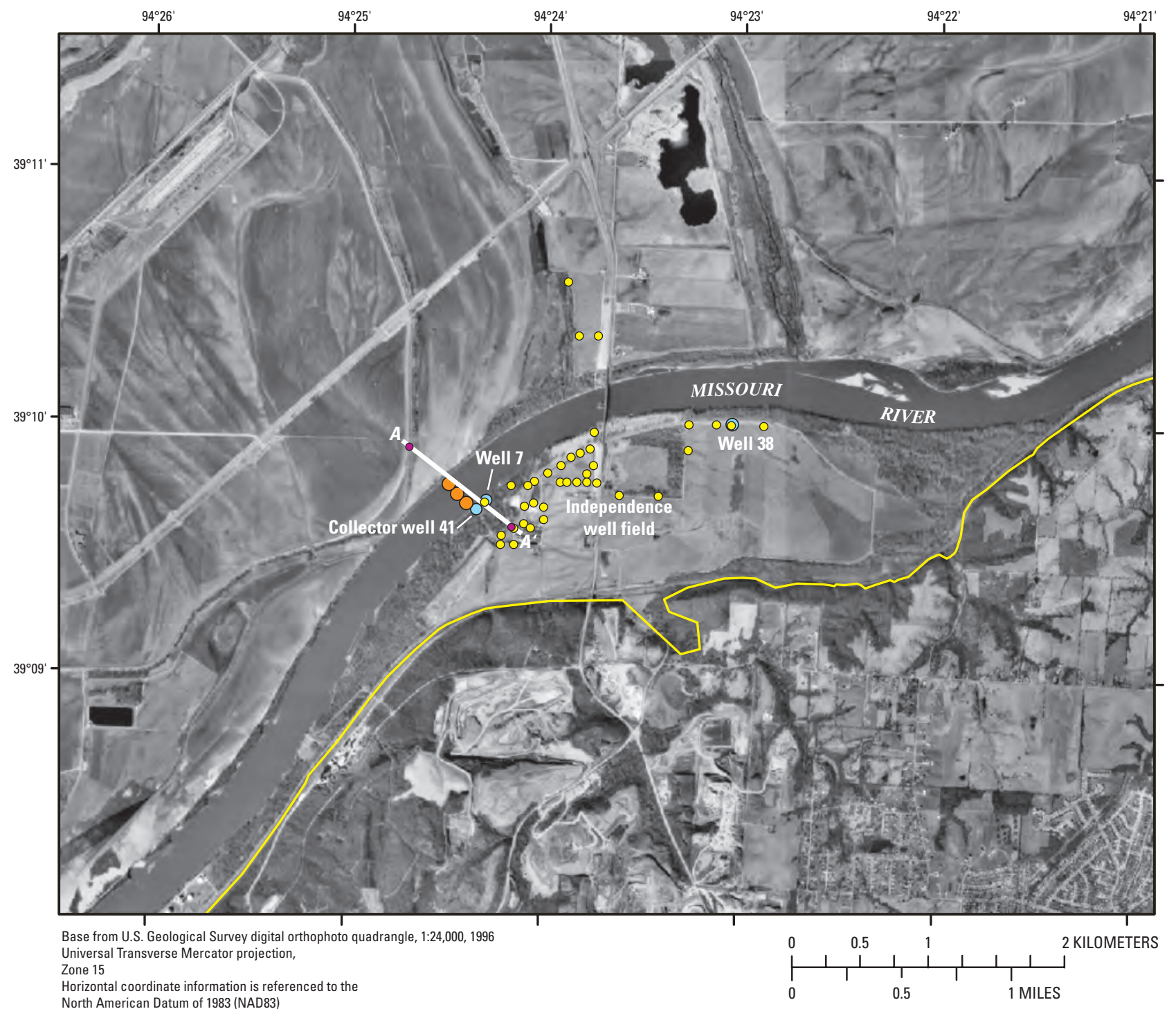

North American Datum of 1983 (NAD83)

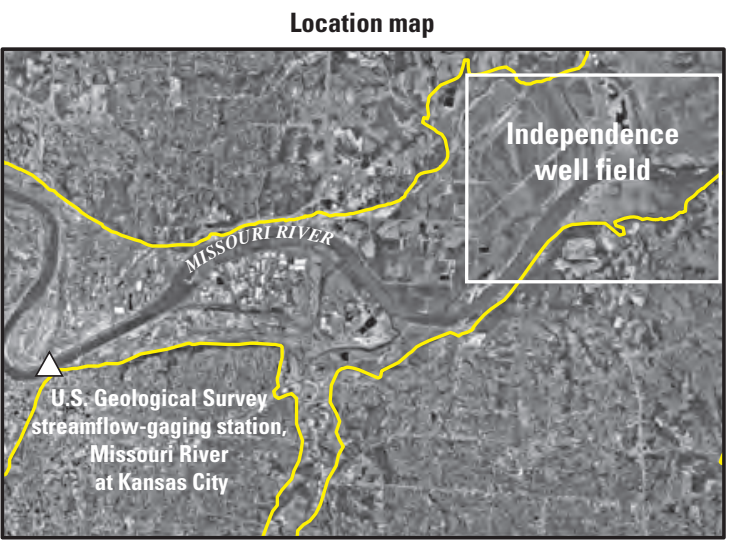

EXPLANATION

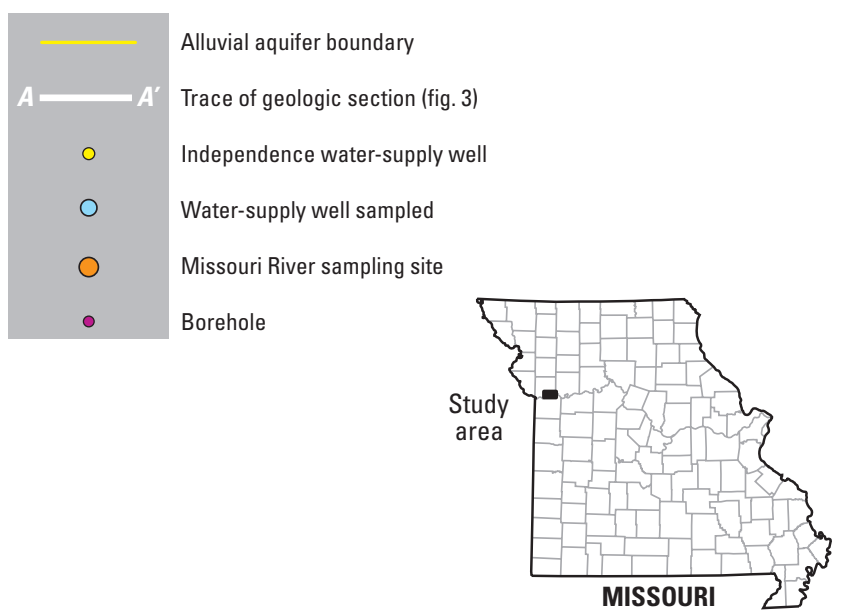

Figure 1. Location of the Independence well field 


\section{Water-Quality Changes Caused by Riverbank Filtration Between the Missouri River and Three Pumping Wells}

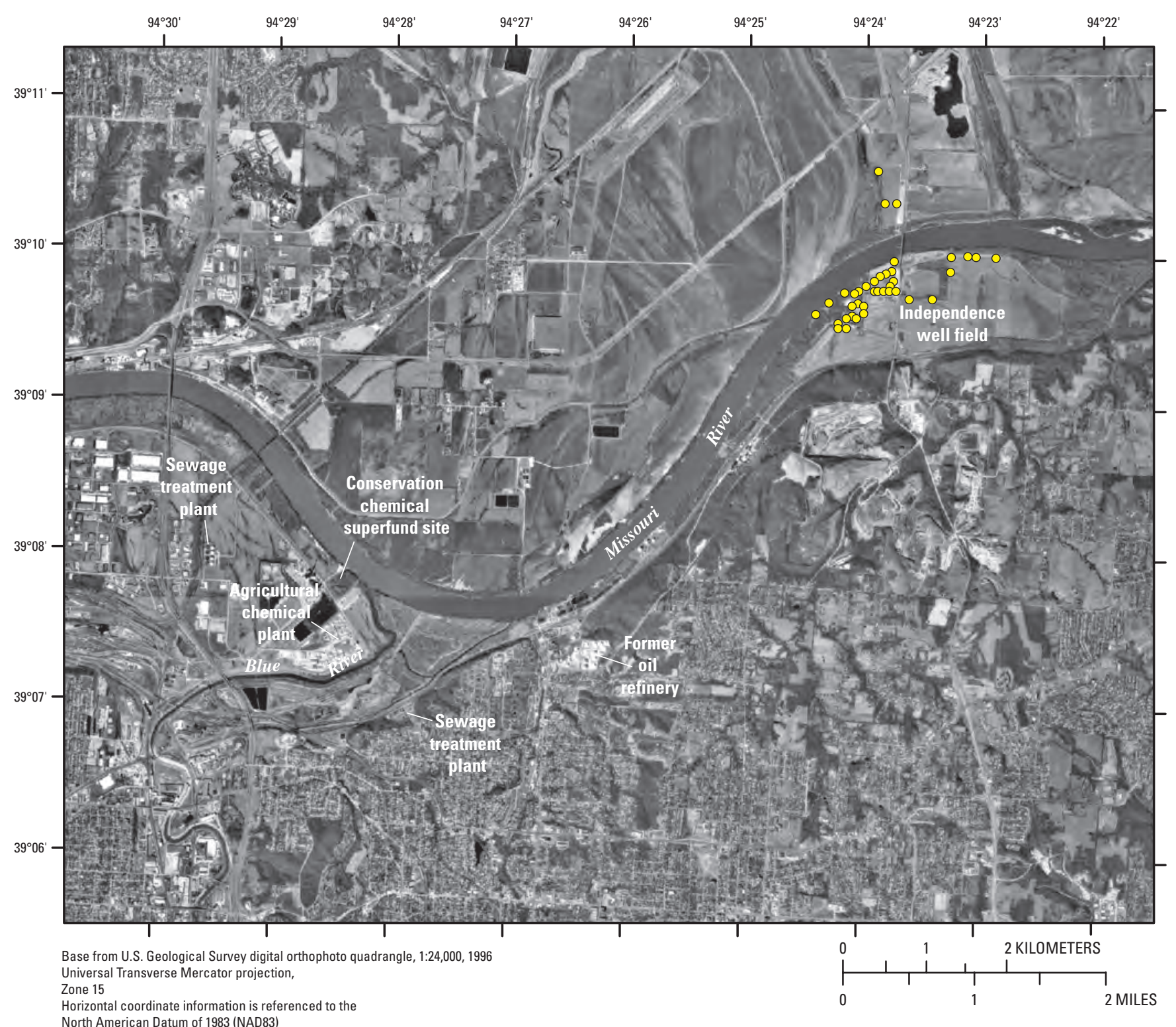

EXPLANATION

O Independence water-supply well

Figure 2. Inflows to the Missouri River that may affect river-water quality near the Independence well field.

by-product precursors and bacteria, protozoa, and viruses by riverbank filtration at the Independence well field can be used to help guide future water-treatment strategies for the Independence well field and other similar public-water supplies.

The scope of the study described in this report was to determine the effects of riverbank filtration on the water quality of induced recharge to the Independence well field from the Missouri River from October 2003 through August 2005. The purpose of this report is to present the results of analyses and variability in water-quality data obtained during the study; describe changes in water quality between the Missouri River and three pumping wells of the Independence well field; describe the relation of haloacetic acid and trihalomethane formation potentials to organic material, organic indicators, and turbidity in samples from the Missouri river and the Independence well field; and describe the cross-sectional distribution of organic wastewater compounds and dissolved oxygen and physical properties in the Missouri River. The International System of Units (SI) is used in this report. However, descriptions of well construction, lithology, and stream discharge are identified based on inch/pound units of measure to allow read- 
ers to easily identify and compare these descriptions with the original sources of data.

\section{Methods of Sample Collection and Analysis}

The Missouri River near the Independence well field, vertical wells 7 and 38, and collector well 41 were sampled during the study (fig. 1). Samples from the Missouri River were collected near the well field from a boat. An integrated-depth sampler was used multiple times from the same vertical section of the river until enough sample volume was collected. The sample was composited in a churn splitter. At times, floating debris in the river prevented sampling from the boat and a grab sample was obtained from the south bank of the Missouri River near the well field. Water samples from vertical and collector wells were collected at the tap of each well. All water samples were collected and preserved according to the methods described in the USGS National Field Manual for the Collection of Water-Quality Data (U.S. Geological Survey, 1997 to 2004).

Wells 7 and 38 and collector well 41 are among the closest wells to the river and thus represented pumping wells with the smallest probable removal rates most likely influenced by Missouri River water quality. Well 7 is approximately $103 \mathrm{ft}$ (feet) deep with a 50-ft screened interval at the bottom of the well. Well 38 is approximately $88 \mathrm{ft}$ deep with a $36-\mathrm{ft}$ screened interval at the bottom of the well. Collector well 41 is a steel rein- forced cylindrical concrete caisson approximately $117 \mathrm{ft}$ deep. Eight, 12-inch laterals between 89 and $215 \mathrm{ft}$ long extend horizontally into the aquifer in two tiers, each with four laterals at the bottom of the caisson. The laterals extend in a fan-like pattern below and parallel to the Missouri River (Camp, Dresser, and McKee, Inc., 2000). A generalized geologic section developed from well logs (Camp, Dresser, and McKee, Inc., 2000; Kelly, 1996) shows the lithology of the Missouri River alluvial aquifer between the Missouri River and collector well 41 (fig. 3). The lithology between the Missouri River and well 7 (located $300 \mathrm{ft}$ to the northeast of collector well 41) and well 38 is similar with finer grained clay, silt and sand overlying layers of fine to coarse grained sand, and sand and gravel. The Missouri River channel bottom intersects the sand layers of the alluvial aquifer, which explains the close interaction between surface water and ground water near the Independence well field.

Water samples from the Missouri River, wells 7 and 38, and collector well 41 were analyzed for dissolved oxygen and physical properties, organic material, organic indicators, nutrients, bacteria, protozoa, and viruses, and formation potentials for haloacetic acids and trihalomethanes. Initial sampling of the Missouri River, wells 7 and 38, and collector well 41 included organic wastewater compounds. Specific analyses and laboratory methods for these constituents are listed in table 1 . The sampling schedule and analysis for each water sample are listed in table 2 .

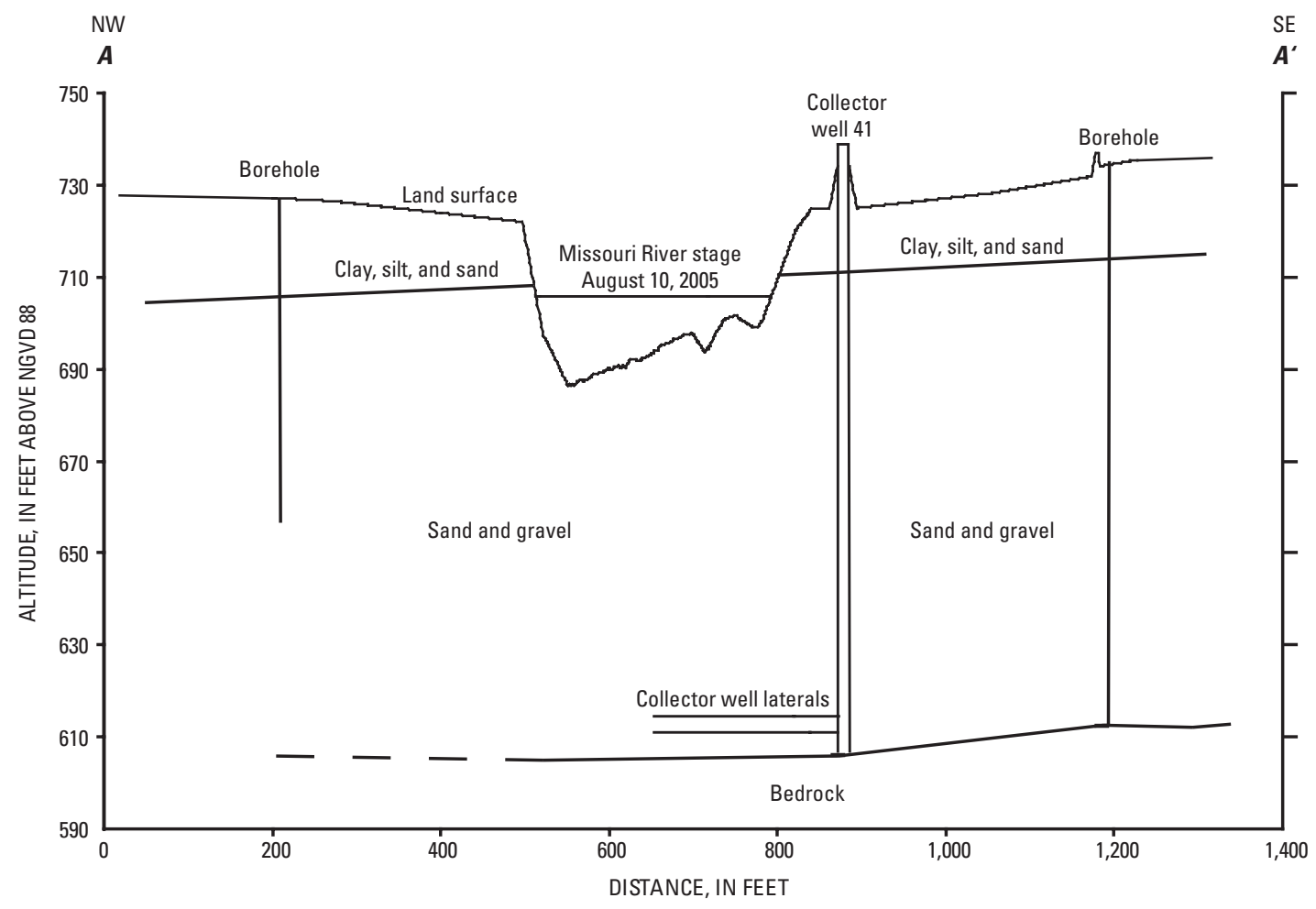

Figure 3. Generalized geologic section $A$ - $A^{\prime}$ (fig. 1) near collector well 41 of the Independence well field. 
Water-Quality Changes Caused by Riverbank Filtration Between the Missouri River and Three Pumping Wells

Table 1. Dissolved oxygen, physical properties, organic material, organic indicators, nutrients, total coliform bacteria, Cryptosporidium, Giardia, total culturable viruses, haloacetic acid formation potentials, trihalomethane formation potentials, and organic wastewater compounds analyses and methods

[CAS, chemical abstracts services; MRL, minimum reporting level; LRL, laboratory reporting level; MCL, maximum contaminant level; DNR, Missouri Department of Natural Resources; analytical method prefix "B, I, O" reference U.S. Geological Survey methods and number prefixes; --, no data; $\mu \mathrm{S} / \mathrm{cm}$, microsiemens per centimeter; na, not applicable; ${ }^{\circ} \mathrm{C}$, degrees Celsius; $\mathrm{mg} / \mathrm{L}$, milligrams per liter; NTU, nephelometric turbidity unit; nm, nanometers; SM, Standard Method; $\mathrm{u} / \mathrm{cm}$, units per centimeter; $\mu \mathrm{g} / \mathrm{L}$, micrograms per liter; col/100 mL, colonies per 100 milliliters; $<$, less than; EPA, U.S. Environmental Protection Agency; \%, percent; oocysts/L, oocysts per liter; cysts/L, cysts per liter; ICR, Information Collection Rule; MPN/100 L, most probable number per 100 liters]

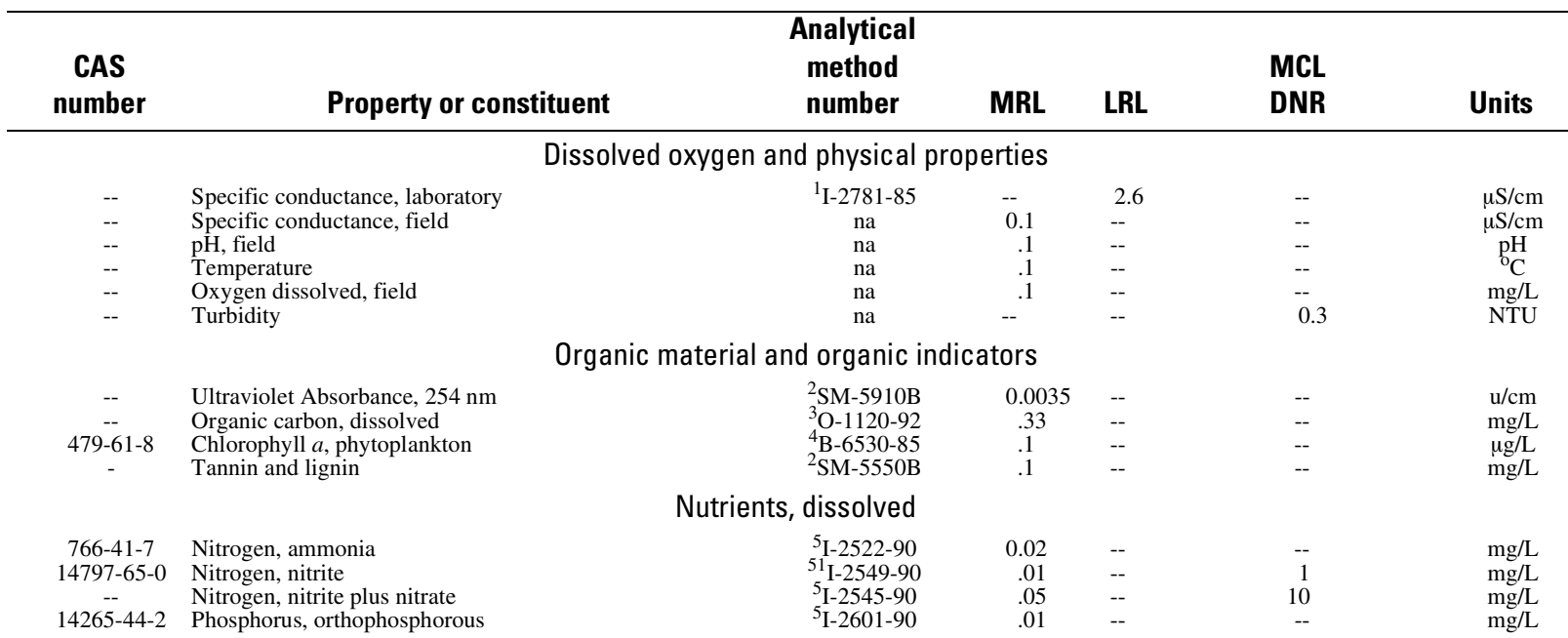

Total coliform bacteria, Cryptosporidium, Giardia, and total culturable viruses

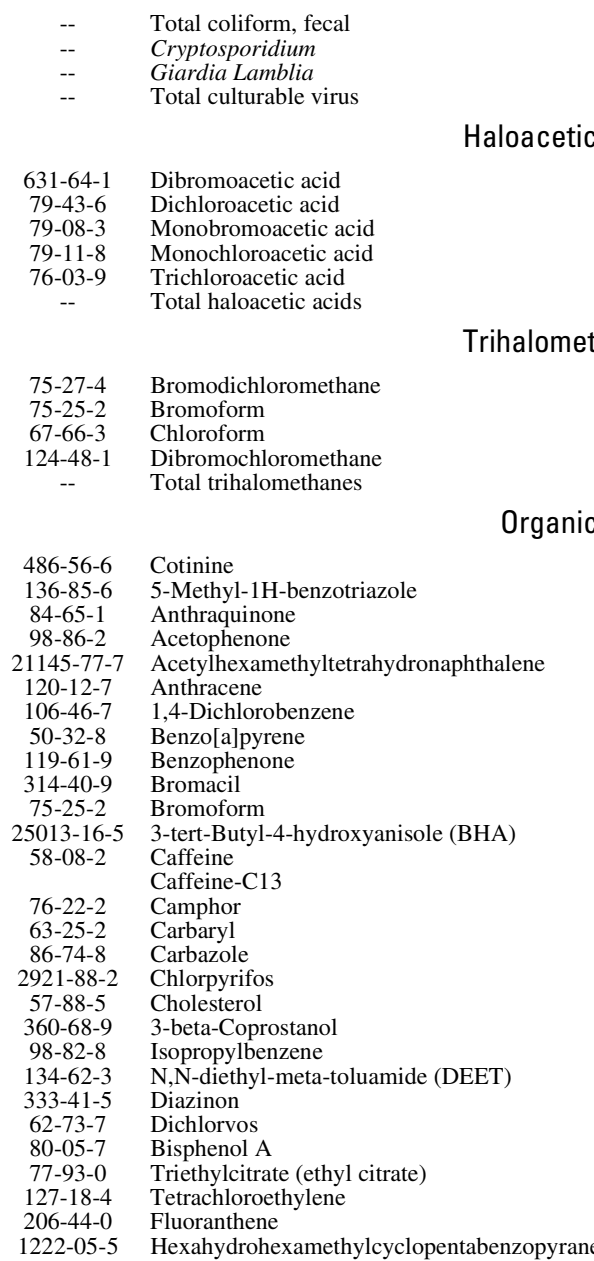

$<1$

--

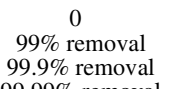

$99.99 \%$ removal $\mathrm{col} / 100 \mathrm{~mL}$ oocysts/L MPN/100 L

aloacetic acid formation potential by compound

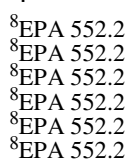

1.0
1.0
1.0
2.0
1.0
--

$\mu \mathrm{g} / \mathrm{L}$

$\mu \mathrm{g} / \mathrm{L}$

$\mu \mathrm{g} / \mathrm{L}$

$\mu \mathrm{g} / \mathrm{L}$

$\mu \mathrm{g} / \mathrm{L}$

$\mu \mathrm{g} / \mathrm{L}$

$\mu \mathrm{g} / \mathrm{L}$

$\mu \mathrm{g} / \mathrm{L}$

$\mu \mathrm{g} / \mathrm{L}$

Organic wastewater compounds, dissolved

$\begin{array}{lrrrl}{ }^{9} \text { EPA 524.2 } & 0.5 & -- & 80 & \mu \mathrm{g} / \mathrm{L} \\ { }^{9} \text { EPA 524.2 } & .5 & -- & 80 & \mu \mathrm{g} / \mathrm{L} \\ { }^{9} \text { EPA 524.2 } & .5 & -- & 80 & \mu \mathrm{g} / \mathrm{L} \\ { }^{9} \text { EPA 524.2 } & .5 & -- & 80 & \mu \mathrm{g} / \mathrm{L} \\ { }^{9} \text { EPA 524.2 } & -- & -- & 80 & \mu \mathrm{g} / \mathrm{L}\end{array}$


Table 1. Dissolved oxygen, physical properties, organic material, organic indicators, nutrients, total coliform bacteria, Cryptosporidium, Giardia, total culturable viruses, haloacetic acid formation potentials, trihalomethane formation potentials, and organic wastewater compounds analyses and methods-Continued

[CAS, chemical abstracts services; MRL, minimum reporting level; LRL, laboratory reporting level; MCL, maximum contaminant level; DNR, Missouri Department of Natural Resources; analytical method prefix "B, I, O" reference U.S. Geological Survey methods and number prefixes; --, no data; $\mu \mathrm{S} / \mathrm{cm}$, microsiemens per centimeter; na, not applicable; ${ }^{\circ} \mathrm{C}$, degrees Celsius; mg/L, milligrams per liter; NTU, nephelometric turbidity unit; nm, nanometers; SM, Standard Method; $\mathrm{u} / \mathrm{cm}$, units per centimeter; $\mu \mathrm{g} / \mathrm{L}$, micrograms per liter; col/100 mL, colonies per $100 \mathrm{milliliters;}$ $<$, less than; EPA, U.S. Environmental Protection Agency; \%, percent; oocysts/L, oocysts per liter; cysts/L, cysts per liter; ICR, Information Collection Rule; MPN/100 L, most probable number per 100 liters]

\begin{tabular}{|c|c|c|c|c|c|c|}
\hline $\begin{array}{c}\text { CAS } \\
\text { number }\end{array}$ & Property or constituent & $\begin{array}{l}\text { Analytical } \\
\text { method } \\
\text { number }\end{array}$ & MRL & $\mathbf{L R L}$ & $\begin{array}{l}\text { MCL } \\
\text { DNR }\end{array}$ & Units \\
\hline \multicolumn{7}{|c|}{ Organic wastewater compounds, dissolved-Continued } \\
\hline $120-72-9$ & Indole & ${ }^{10} \mathrm{O}-1433-01$ & 0.5 & -- & -- & $\mu \mathrm{g} / \mathrm{L}$ \\
\hline $124-76-5$ & Isoborneol & ${ }^{10} \mathrm{O}-1433-01$ & .5 & -- & -- & $\mu \mathrm{g} / \mathrm{L}$ \\
\hline $78-59-1$ & Isophorone & ${ }^{10} \mathrm{O}-1433-01$ & .5 & -- & -- & $\mu \mathrm{g} / \mathrm{L}$ \\
\hline $119-65-3$ & Isoquinoline & ${ }^{10} \mathrm{O}-1433-01$ & .5 & -- & -- & $\mu \mathrm{g} / \mathrm{L}$ \\
\hline $5989-27-5$ & d-Limonene & ${ }^{10} \mathrm{O}-1433-01$ & .5 & -- & -- & $\mu \mathrm{g} / \mathrm{L}$ \\
\hline $89-78-1$ & Menthol & ${ }^{10} \mathrm{O}-1433-01$ & .5 & -- & -- & $\mu \mathrm{g} / \mathrm{L}$ \\
\hline $57837-19-1$ & Metalaxyl & ${ }^{10} \mathrm{O}-1433-01$ & .5 & -- & -- & $\mu \mathrm{g} / \mathrm{L}$ \\
\hline $51218-45-2$ & Metolachlor & ${ }^{10} \mathrm{O}-1433-01$ & .5 & -- & -- & $\mu \mathrm{g} / \mathrm{L}$ \\
\hline $91-20-3$ & Naphthalene & ${ }^{10} \mathrm{O}-1433-01$ & .5 & -- & -- & $\mu \mathrm{g} / \mathrm{L}$ \\
\hline $90-12-0$ & 1-Methylnaphthalene & ${ }^{10} \mathrm{O}-1433-01$ & .5 & -- & -- & $\mu \mathrm{g} / \mathrm{L}$ \\
\hline $581-42-0$ & 2,6-Dimethylnaphthalene & ${ }^{10} \mathrm{O}-1433-01$ & .5 & - & - & $\mu \mathrm{g} / \mathrm{L}$ \\
\hline $91-57-6$ & 2-Methylnaphthalene & ${ }^{10} \mathrm{O}-1433-01$ & .5 & -- & -- & $\mu \mathrm{g} / \mathrm{L}$ \\
\hline $26027-38-2$ & Nonylphenol,diethoxy-(total) & ${ }^{10} \mathrm{O}-1433-01$ & 5.0 & -- & -- & $\mu \mathrm{g} / \mathrm{L}$ \\
\hline $26636-32-8$ & Octylphenol,diethoxy- & ${ }^{10} \mathrm{O}-1433-01$ & 1.0 & -- & -- & $\mu \mathrm{g} / \mathrm{L}$ \\
\hline $26636-32-8$ & Octylphenol,monoethoxy- & ${ }^{10} \mathrm{O}-1433-01$ & 1.0 & -- & -- & $\mu \mathrm{g} / \mathrm{L}$ \\
\hline $106-44-5$ & p-Cresol & ${ }^{10} \mathrm{O}-1433-01$ & 1.0 & -- & -- & $\mu \mathrm{g} / \mathrm{L}$ \\
\hline $599-64-4$ & 4-Cumylphenol & ${ }^{10} \mathrm{O}-1433-01$ & 1.0 & -- & -- & $\mu \mathrm{g} / \mathrm{L}$ \\
\hline $84852-15-3$ & para-Nonylphenol (total) & ${ }^{10} \mathrm{O}-1433-01$ & 5.0 & -- & -- & $\mu \mathrm{g} / \mathrm{L}$ \\
\hline $1806-26-4$ & 4-n-Octylphenol & ${ }^{10} \mathrm{O}-1433-01$ & 1.0 & -- & -- & $\mu \mathrm{g} / \mathrm{L}$ \\
\hline $140-66-9$ & 4-tert-Octylphenol & ${ }^{10} \mathrm{O}-1433-01$ & 1.0 & -- & -- & $\mu \mathrm{g} / \mathrm{L}$ \\
\hline $85-01-8$ & Phenanthrene & ${ }^{10} \mathrm{O}-1433-01$ & .5 & -- & -- & $\mu \mathrm{g} / \mathrm{L}$ \\
\hline $108-95-2$ & Phenol & ${ }^{10} \mathrm{O}-1433-01$ & .5 & -- & -- & $\mu \mathrm{g} / \mathrm{L}$ \\
\hline $87-86-5$ & Pentachlorophenol & ${ }^{10} \mathrm{O}-1433-01$ & 2.0 & -- & -- & $\mu \mathrm{g} / \mathrm{L}$ \\
\hline $126-73-8$ & Tributylphosphate & ${ }^{10} \mathrm{O}-1433-01$ & .5 & -- & -- & $\mu \mathrm{g} / \mathrm{L}$ \\
\hline $115-86-6$ & Triphenylphosphate & ${ }^{10} \mathrm{O}-1433-01$ & .5 & -- & -- & $\mu \mathrm{g} / \mathrm{L}$ \\
\hline $78-51-3$ & Tris(2-butoxyethyl)phosphate & ${ }^{10} \mathrm{O}-1433-01$ & .5 & -- & -- & $\mu \mathrm{g} / \mathrm{L}$ \\
\hline $115-96-8$ & Tris(2-chloroethyl)phosphate & ${ }^{10} \mathrm{O}-1433-01$ & .5 & -- & -- & $\mu \mathrm{g} / \mathrm{L}$ \\
\hline $1610-18-0$ & Prometon & ${ }^{10} \mathrm{O}-1433-01$ & .5 & -- & -- & $\mu \mathrm{g} / \mathrm{L}$ \\
\hline $129-00-0$ & Pyrene & ${ }^{10} \mathrm{O}-1433-01$ & .5 & -- & -- & $\mu \mathrm{g} / \mathrm{L}$ \\
\hline $119-36-8$ & Methylsalicylate & ${ }^{10} \mathrm{O}-1433-01$ & .5 & -- & -- & $\mu \mathrm{g} / \mathrm{L}$ \\
\hline $83-34-1$ & 3-Methyl-1(H)-indole(Skatole) & ${ }^{10} \mathrm{O}-1433-01$ & 1.0 & -- & -- & $\mu \mathrm{g} / \mathrm{L}$ \\
\hline $83-46-5$ & beta-Sitosterol & ${ }^{10} \mathrm{O}-1433-01$ & 2.0 & -- & -- & $\mu \mathrm{g} / \mathrm{L}$ \\
\hline $19466-47-8$ & beta-Stigmastanol & ${ }^{10} \mathrm{O}-1433-01$ & 2.0 & -- & -- & $\mu \mathrm{g} / \mathrm{L}$ \\
\hline $3380-34-5$ & Triclosan & ${ }^{10} \mathrm{O}-1433-01$ & 1.0 & -- & -- & $\mu \mathrm{g} / \mathrm{L}$ \\
\hline $13674-87-8$ & Tris(dichlorisopropyl)phosphate & ${ }^{10} \mathrm{O}-1433-01$ & .5 & -- & -- & $\mu \mathrm{g} / \mathrm{L}$ \\
\hline
\end{tabular}

${ }^{1}$ Fishman and Friedman (1989).

${ }^{2}$ Standard Methods $20^{\text {th }}$ Ed. (1998).

${ }^{3}$ Brenton and Arnett (1993).

${ }^{4}$ Britton and Greeson (1987).

${ }^{5}$ Fishman (1993).

${ }^{6}$ U.S. Environmental Protection Agency (2001).

${ }^{7}$ U.S. Environmental Protection Agency (1996).

${ }^{8}$ U.S. Environmental Protection Agency (1995a).

${ }^{9}$ U.S. Environmental Protection Agency (1995b).

${ }^{10}$ Zaugg and others (2002). 


\begin{tabular}{|c|c|c|c|c|c|c|c|c|c|c|c|c|}
\hline $\begin{array}{c}\text { Grab } \\
\text { sample }\end{array}$ & $\begin{array}{c}\text { Sample } \\
\text { date }\end{array}$ & $\begin{array}{c}\text { Dissolved oxygen } \\
\text { and physical } \\
\text { properties }\end{array}$ & $\begin{array}{c}\text { Ultraviolet } \\
\text { absorbance } \\
254 \mathrm{~nm}\end{array}$ & $\begin{array}{c}\text { Chlorophyll } \\
a\end{array}$ & $\begin{array}{c}\text { Dissolved } \\
\text { organic } \\
\text { carbon }\end{array}$ & $\begin{array}{l}\text { Tannin } \\
\text { and } \\
\text { lignin }\end{array}$ & $\begin{array}{l}\text { Dissolved } \\
\text { nutrients }\end{array}$ & $\begin{array}{c}\text { Total } \\
\text { coliform } \\
\text { bacteria }\end{array}$ & $\begin{array}{c}\text { Cryptosporidium } \\
\text { and } \\
\text { Giardia }\end{array}$ & $\begin{array}{c}\text { Total } \\
\text { culturable } \\
\text { virus }\end{array}$ & $\begin{array}{c}\text { Haloacetic acid } \\
\text { and } \\
\text { trihalomethane } \\
\text { formation potential }\end{array}$ & $\begin{array}{c}\text { Dissolved } \\
\text { organic } \\
\text { wastewater } \\
\text { compounds }\end{array}$ \\
\hline \multicolumn{13}{|c|}{ Missouri River, middle (Identifier, 390945094242400 , fig. 1) } \\
\hline-- & $10 / 29 / 2003$ & $\mathrm{X}$ & $\mathrm{X}$ & $\mathrm{X}$ & $\mathrm{X}$ & $\mathrm{X}$ & -- & -- & $\mathrm{X}$ & $\mathrm{X}$ & $\mathrm{x}$ & $\mathrm{x}$ \\
\hline-- & $1029 / 2003$ & $\mathrm{X}$ & $\mathrm{X}$ & $\mathrm{x}$ & $\mathrm{X}$ & $\mathrm{X}$ & -- & -- & -- & -- & -- & - \\
\hline -- & $12 / 17 / 2003$ & $\mathrm{x}$ & $\mathrm{X}$ & $\mathrm{x}$ & $\mathrm{X}$ & $\mathrm{X}$ & -- & -- & $\mathrm{x}$ & -- & $\mathrm{X}$ & -- \\
\hline $\mathrm{X}$ & $1 / 28 / 2004$ & $\mathrm{X}$ & $\mathrm{X}$ & $\mathrm{X}$ & $\mathrm{X}$ & $\mathrm{X}$ & $\mathrm{X}$ & $\mathrm{X}$ & $\mathrm{X}$ & -- & $\mathrm{x}$ & -- \\
\hline- & $2 / 24 / 2004$ & $\mathrm{X}$ & $\mathrm{X}$ & $\mathrm{X}$ & $\mathrm{X}$ & $\mathrm{X}$ & $\mathrm{X}$ & $\mathrm{X}$ & $\mathrm{X}$ & $\mathrm{X}$ & $\mathrm{X}$ & -- \\
\hline-- & $3 / 30 / 2004$ & $\hat{x}$ & $\hat{x}$ & $\hat{\mathrm{X}}$ & $\hat{x}$ & $\hat{x}$ & $\hat{x}$ & $\hat{x}$ & $\hat{\mathrm{X}}$ & $\hat{x}$ & $\hat{x}$ & -- \\
\hline $\mathrm{X}$ & $3 / 30 / 2004$ & $\mathrm{X}$ & $\mathrm{X}$ & $\mathrm{X}$ & $\mathrm{X}$ & $\mathrm{X}$ & $\mathrm{X}$ & - & -- & - & - & -- \\
\hline -- & $4 / 27 / 2004$ & $\mathrm{X}$ & $\mathrm{X}$ & $X$ & $\mathrm{X}$ & $\mathrm{X}$ & $\mathrm{X}$ & $\mathrm{X}$ & $\mathrm{X}$ & $\mathrm{X}$ & $\mathrm{X}$ & -- \\
\hline $\mathrm{X}$ & $5 / 25 / 2004$ & $\mathrm{X}$ & $\mathrm{X}$ & $\mathrm{X}$ & $\mathrm{X}$ & $\mathrm{X}$ & $\mathrm{X}$ & & $\mathrm{X}$ & $\mathrm{X}$ & -- & -- \\
\hline-- & $6 / 30 / 2004$ & $\mathrm{X}$ & $\mathrm{X}$ & $\mathrm{X}$ & $\mathrm{X}$ & $\mathrm{X}$ & $\mathrm{X}$ & $\mathrm{X}$ & $\mathrm{X}$ & $\mathrm{X}$ & -- & -- \\
\hline $\mathrm{X}$ & $8 / 31 / 2004$ & $\mathrm{X}$ & $\mathrm{X}$ & -- & $\mathrm{X}$ & & $\mathrm{X}$ & & $\mathrm{X}$ & $\mathrm{X}$ & -- & -- \\
\hline \multicolumn{13}{|c|}{ Missouri River, south (Identifier, 390942094242100 , fig. 1) } \\
\hline -- & $10 / 29 / 2003$ & $\mathrm{X}$ & -- & -- & -- & -- & -- & -- & -- & -- & -- & $\mathrm{x}$ \\
\hline-- & 2/24/2004 & $\mathrm{X}$ & -- & -- & -- & -- & -- & -- & $\mathrm{X}$ & -- & -- & -- \\
\hline \multicolumn{13}{|c|}{ Missouri River, north (Identifier, 390947094242600. fig. 1) } \\
\hline-- & $10 / 29 / 2003$ & $\mathrm{X}$ & -- & -- & -- & -- & -- & -- & -- & -- & -- & $\mathrm{X}$ \\
\hline \multicolumn{13}{|c|}{ Well 7 (Identifier, 390949094241300, fig. 1) } \\
\hline -- & $11 / 19 / 2003$ & $\mathrm{X}$ & $\mathrm{X}$ & $\mathrm{X}$ & $\mathrm{X}$ & $\mathrm{X}$ & -- & -- & $\mathrm{X}$ & $\mathrm{X}$ & $\mathrm{x}$ & $\mathrm{x}$ \\
\hline -- & $12 / 17 / 2003$ & $\mathrm{x}$ & $\mathrm{x}$ & -- & $\mathrm{X}$ & -- & -- & -- & -- & -- & $\hat{x}$ & -- \\
\hline -- & $1 / 28 / 2004$ & $\mathrm{X}$ & $\mathrm{X}$ & -- & $\mathrm{X}$ & -- & -- & -- & -- & -- & $\mathrm{X}$ & -- \\
\hline-- & $2 / 25 / 2004$ & $\mathrm{X}$ & $\mathrm{X}$ & -- & $\mathrm{X}$ & -- & -- & -- & -- & -- & $\mathrm{X}$ & -- \\
\hline-- & $3 / 31 / 2004$ & $\mathrm{X}$ & $\mathrm{X}$ & $\mathrm{X}$ & $\mathrm{X}$ & $\mathrm{X}$ & $\mathrm{X}$ & -- & $\mathrm{X}$ & $\mathrm{X}$ & $\mathrm{X}$ & -- \\
\hline-- & $5 / 4 / 2004$ & $\mathrm{X}$ & $x$ & -- & $\mathrm{X}$ & $\mathrm{X}$ & $\mathrm{X}$ & -- & -- & -- & $\mathrm{X}$ & -- \\
\hline-- & $5 / 26 / 2004$ & $\mathrm{X}$ & $x$ & -- & $\mathrm{X}$ & -- & $\mathrm{X}$ & -- & -- & -- & -- & -- \\
\hline-- & $7 / 13 / 2004$ & $\mathrm{X}$ & $\mathrm{X}$ & $\mathrm{X}$ & $\mathrm{X}$ & $\mathrm{x}$ & $\mathrm{X}$ & -- & $\mathrm{x}$ & $\mathrm{X}$ & -- & -- \\
\hline-- & 9/8/2004 & $\mathrm{X}$ & $\mathrm{X}$ & -- & $\mathrm{X}$ & -- & $\mathrm{x}$ & $\mathrm{X}$ & -- & -- & -- & -- \\
\hline \multicolumn{13}{|c|}{ Well 38 (Identifier, 391000094230200 , fig. 1) } \\
\hline-- & $11 / 5 / 2003$ & $\mathrm{X}$ & $\mathrm{X}$ & $\mathrm{x}$ & $\mathrm{X}$ & -- & -- & -- & $\mathrm{X}$ & $\mathrm{X}$ & $\mathrm{X}$ & $\mathrm{x}$ \\
\hline-- & $12 / 17 / 2003$ & $\mathrm{X}$ & $\mathrm{X}$ & -- & $\mathrm{X}$ & -- & -- & -- & -- & -- & $\mathrm{X}$ & -- \\
\hline -- & $1 / 28 / 2004$ & $\mathrm{X}$ & $\mathrm{X}$ & -- & $\mathrm{X}$ & -- & -- & -- & -- & -- & $\mathrm{X}$ & -- \\
\hline-- & $2 / 25 / 2004$ & $\mathrm{X}$ & $\mathrm{X}$ & -- & $\mathrm{X}$ & -- & -- & -- & -- & -- & $\mathrm{X}$ & -- \\
\hline-- & $3 / 31 / 2004$ & $\mathrm{X}$ & $\mathrm{X}$ & $\mathrm{X}$ & $\mathrm{X}$ & -- & $\mathrm{X}$ & -- & $\mathrm{x}$ & $\mathrm{X}$ & $\mathrm{X}$ & -- \\
\hline -- & $5 / 4 / 2004$ & $\mathrm{X}$ & $\mathrm{X}$ & -- & $\mathrm{X}$ & $\mathrm{X}$ & $\mathrm{X}$ & -- & - & - & $\mathrm{X}$ & -- \\
\hline-- & $5 / 26 / 2004$ & $\mathrm{X}$ & $\mathrm{X}$ & -- & $\mathrm{X}$ & -- & $\mathrm{X}$ & -- & -- & -- & -- & -- \\
\hline -- & $7 / 13 / 2004$ & $\mathrm{X}$ & $X$ & -- & $\mathrm{X}$ & $\mathrm{X}$ & $\mathrm{X}$ & -- & $\mathrm{X}$ & $\mathrm{X}$ & -- & -- \\
\hline-- & 9/8/2004 & $\mathrm{X}$ & $\mathrm{X}$ & -- & $\mathrm{x}$ & -- & $\mathrm{X}$ & $\mathrm{X}$ & -- & -- & -- & -- \\
\hline \multicolumn{13}{|c|}{ Collector Well 41 (Identifier, 390940094242500, fig. 1) } \\
\hline -- & $11 / 19 / 2003$ & $\mathrm{X}$ & $\mathrm{X}$ & $\mathrm{x}$ & $\mathrm{X}$ & -- & -- & -- & $\mathrm{x}$ & $\mathrm{X}$ & $\mathrm{x}$ & $\mathrm{x}$ \\
\hline-- & $11 / 19 / 2003$ & $\mathrm{X}$ & $\mathrm{X}$ & -- & $\mathrm{X}$ & $\mathrm{X}$ & -- & -- & -- & -- & -- & $\mathrm{x}$ \\
\hline-- & $12 / 17 / 2003$ & $\mathrm{X}$ & $X$ & $\mathrm{X}$ & $\mathrm{X}$ & $\mathrm{X}$ & -- & -- & $\mathrm{x}$ & $\mathrm{X}$ & $\mathrm{X}$ & -- \\
\hline -- & $1 / 28 / 2004$ & $\mathrm{X}$ & $\mathrm{X}$ & $\mathrm{X}$ & $\mathrm{X}$ & $\mathrm{X}$ & $\mathrm{X}$ & $\mathrm{X}$ & $\mathrm{X}$ & $\mathrm{X}$ & $\mathrm{X}$ & -- \\
\hline -- & $2 / 25 / 2004$ & $\mathrm{X}$ & $\mathrm{X}$ & $\mathrm{X}$ & $\mathrm{X}$ & $\mathrm{X}$ & $\mathrm{X}$ & - & $\mathrm{X}$ & $\mathrm{X}$ & $\mathrm{X}$ & -- \\
\hline -- & $3 / 30 / 2004$ & $\mathrm{X}$ & $\mathrm{X}$ & $\mathrm{X}$ & $X$ & -- & $\mathrm{X}$ & -- & $\mathrm{X}$ & $\mathrm{X}$ & $\mathrm{X}$ & -- \\
\hline -- & $3 / 30 / 2004$ & $\mathrm{X}$ & $\mathrm{X}$ & $\mathrm{X}$ & $\mathrm{X}$ & -- & $\mathrm{X}$ & -- & - & - & -- & -- \\
\hline -- & $5 / 4 / 2004$ & $\mathrm{X}$ & $\mathrm{X}$ & $\mathrm{X}$ & $\mathrm{X}$ & $\mathrm{X}$ & $\mathrm{X}$ & -- & $\mathrm{X}$ & $\mathrm{X}$ & $\mathrm{X}$ & -- \\
\hline -- & $5 / 26 / 2004$ & $\mathrm{X}$ & $\mathrm{X}$ & $\mathrm{X}$ & $\mathrm{X}$ & $\mathrm{X}$ & $\mathrm{X}$ & -- & $\mathrm{X}$ & $\mathrm{X}$ & -- & -- \\
\hline-- & $7 / 13 / 2004$ & $\mathrm{X}$ & $\mathrm{X}$ & $\mathrm{X}$ & $\mathrm{X}$ & $\mathrm{X}$ & $\mathrm{X}$ & -- & $\mathrm{X}$ & $\mathrm{X}$ & -- & -- \\
\hline-- & 9/8/2004 & $\mathrm{X}$ & $\mathrm{X}$ & -- & $\mathrm{X}$ & -- & $\mathrm{X}$ & $\mathrm{X}$ & $\mathrm{x}$ & $\mathrm{X}$ & -- & -- \\
\hline
\end{tabular}


Water samples from wells 7 and 38, and collector well 41 were collected and analyzed to determine changes in dissolved oxygen and physical properties, organic materials, organic indicators, nutrients, bacteria, protozoa, and viruses. Haloacetic acid and trihalomethane formation potentials were analyzed in river and well samples at the beginning of the study to determine their correlation with organic materials and organic indicators.

Water temperature and specific conductance in the collector well were measured to identify temperature or specific conductance signatures that can be used to determine the traveltime between the river and the collector well. Monthly samples were collected from wells 7 and 38 and collector well 41 . The water quality of well samples was compared to river samples and examined for trends. Selected samples were analyzed for tannin and lignin, chlorophyll $a$, total coliform bacteria, Cryptosporidium, Giardia, and total culturable viruses to allow a qualitative comparison of these constituents in these wells to that in the collector well. This comparison was used to indicate the log removals of total coliform bacteria, Cryptosporidium, Giardia, total culturable viruses, and the change in concentration of natural organic material precursors to disinfection by-products between the Missouri River and supply wells of the Independence well field.

Dissolved oxygen and physical properties in the Missouri River and in ground water were measured at the time of sampling using methods described in the USGS National Field Manual for the Collection of Water-Quality Data (U.S. Geological Survey, 1997 to 2004). Dissolved oxygen was measured with a temperature-compensated portable dissolved oxygen meter calibrated to air saturated water and checked with a zero dissolved oxygen solution. Values for $\mathrm{pH}$ were measured using a temperature-compensated portable meter calibrated with standard buffers that bracketed the expected sample $\mathrm{pH}$ values. Specific conductance was measured using a portable conductivity meter with temperature compensation and calibrated with standard buffers that bracketed the expected sample specific conductance values. Water temperature was measured using a thermistor thermometer. Turbidity was measured in nephelometric turbidity units using a portable turbidimeter calibrated with formazin standards for turbidity.

A multi-parameter water-quality monitor mounted on a boat was used to measure dissolved oxygen, specific conductance, temperature, and turbidity in the Missouri River. Sensors on the monitor were cleaned and calibrated according to the manufacturer's specifications (Wagner and others, 2000). A Global Positioning Satellite receiver recorded the position of the monitor for each measurement to reference the water-quality measurement to a specific location on the Missouri River. Measurements of water quality and position were made for 142 cross sections (4,280 measurements) on August 8, 9, and 10, 2005. The data were input into geographic information system software and interpolated to produce the cross-sectional distribution of each measured water-quality property.

Samples for nutrient analysis were filtered through a 0.45$\mu \mathrm{m}$ (micrometer) glass fiber filter and collected in $125-\mathrm{mL}$ (milliliter) brown polyethylene bottles, chilled to $4{ }^{\circ} \mathrm{C}$ (degrees Celsius) and shipped on the day of sample collection to the USGS National Water-Quality Laboratory in Lakewood, Colorado (NWQL) or the USGS Ocala Water Quality and Research Laboratory in Ocala Florida (OCALA). Samples for dissolved organic carbon were filtered through a $0.45-\mu \mathrm{m}$ glass fiber filter, collected in 125-mL amber glass bottles that had been baked at $400{ }^{\circ} \mathrm{C}$, and preserved with $4.5 \mathrm{~N}$ sulfuric acid. Samples for chlorophyll $a$ were collected on 47-mm (millimeter) diameter glass fiber filters. The filters were placed in glass vials and wrapped in aluminum foil. Samples for tannin and lignin were collected in a $250-\mathrm{mL}$ polyethylene bottle. Samples for ultraviolet absorbance were filtered through a $0.45-\mu \mathrm{m}$ glass fiber filter and collected in $125-\mathrm{mL}$ amber glass bottle. All samples for analysis of organic carbon, chlorophyll $a$, and tannin and lignin were chilled to $4{ }^{\circ} \mathrm{C}$ and shipped on the day of sample collection to the NWQL or OCALA.

Total coliform bacteria samples were prepared for analysis within 1 hour of collection at the USGS laboratory in Lee's Summit, Missouri. Total coliform bacteria analysis was performed using the membrane-filtration method as described in the USGS National Field Manual for the Collection of WaterQuality Data (U.S. Geological Survey, 1997 to 2004). Cryptosporidium and Giardia samples from the Missouri River were collected in a 10-L (liter) cubitainer. Samples for Cryptosporidium and Giardia from wells were collected on an Envirocheck HV (TM) filter using a laboratory supplied filtering apparatus. Total culturable virus samples were collected using a laboratory supplied cartridge filter and filtering apparatus. Cryptosporidium, Giardia, and total culturable virus samples were chilled to $4{ }^{\circ} \mathrm{C}$ and shipped on the day of sample collection to Environmental Health Laboratories (accredited by the National Environmental Laboratory Accreditation Conference), South Bend, Indiana, for analysis.

Samples for haloacetic acid and trihalomethane formation potentials were collected in 1-L glass amber bottles, chilled to $4{ }^{\circ} \mathrm{C}$, and shipped on the day of sample collection to Environmental Health Laboratories for analysis. In the laboratory, samples analyzed for haloacetic acid and trihalomethane formation potentials were dosed with chlorine, adjusted to a neutral $\mathrm{pH}$, incubated for 7 days at $25^{\circ} \mathrm{C}$, and analyzed at the end of the incubation period. Samples for organic wastewater compounds were filtered through a $0.45-\mu \mathrm{m}$ glass fiber filter, collected in a 1-L glass amber bottle that had been baked at $450{ }^{\circ} \mathrm{C}$, chilled to $4{ }^{\circ} \mathrm{C}$, and shipped on the day of sample collection to the NWQL.

Analytical results are presented using the laboratory minimum reporting level for all non-detect values. For statistical calculations, the laboratory reporting limit was used in place of non-detect values. This resulted in the smallest, most conservative estimate of bank-filtration removal rates. Analytical results from Missouri River water samples and Independence well water samples were compared using a Mann-Whitney test (Helsel and Hirsch, 1992). The null hypothesis was that there was no statistically significant difference between analytical results for water samples from the Missouri River and the Independence well field wells at a significance level of 0.05 . 


\section{Quality-Assurance Methods and Results}

Quality-assurance/quality-control methodology included sequential replicate samples, field spikes, and sampling protocols outlined in the National Field Manual for the Collection of Water-Quality Data (U.S. Geological Survey, 1997 to 2004). Sequential replicate samples are two complete samples collected one after the other, preserved, packed for shipping, analyzed identically, and used to assess sample-collection technique, sample processing, and laboratory analysis. Spiked samples were used to determine analyte recovery rates and degradation during shipping.

Replicate samples for nutrients analysis were obtained for the Missouri River and for collector well 41 on March 30, 2004. Replicate samples for organic carbon were obtained for the Missouri River on October 29, 2003, and March 30, 2004, and for collector well 41 on November 19, 2003, and March 30, 2004.

One sample spiked with Cryptosporidium oocysts and Giardia cysts was prepared on February 24, 2004, using organic-free water and sent to the laboratory to assess recovery rates for this analysis. A 10-L sample was seeded with EasySeed $^{\mathrm{TM}}$, a 5-mL test-tube containing 100 Cryptosporidium oocysts and 100 Giardia cysts in $1 \mathrm{~mL}$ of saline solution and provided by BTF Decisive Microbiology, Sydney, Australia.

Results between samples and replicates are similar, and indicate that the sample-collection techniques and laboratory analyses were accurately representing concentrations in the river and wells (table 3 ). Recovery rates indicated by the spike sample were 6.7 oocysts/L (67 percent; oocysts per liter) for Cryptosporidium and 4.5 cysts/L ( 45 percent; cysts per liter) for Giardia. These rates are similar to other reported recovery rates for EPA (Environmental Protection Agency) method 1623

(DiGiorgio and others, 2002).

\section{Results of Analyses and Variability in Water Quality}

Water-quality changes in the Missouri River (with time and discharge) and in wells (with time) were determined from Missouri River samples near the Independence well field and from wells 7 and 38, and collector well 41 (fig. 1). Many seasonal water-quality changes in the Missouri River are related to changes in discharge. Discharge at the USGS streamflow-gaging station at Kansas City (station number 06893000) and sample-collection dates for the Missouri River near the Independence well field are shown in figure 4.

Results of analyses for dissolved oxygen, $\mathrm{pH}$, specific conductance, temperature, and turbidity are listed in table 4 and are summarized in figure 5. Median values of dissolved oxygen, $\mathrm{pH}$, and turbidity in Missouri River samples were substantially larger than in samples from wells 7 and 38 and collector well 41. The median temperatures for samples from the Missouri River and the wells are similar, but the temperature range for Missouri River samples was larger than for the wells. Median values of specific conductance are slightly smaller for samples from the Missouri River than for samples from the wells. Changes in concentration of dissolved oxygen and values of physical properties in water samples from the Missouri River, wells 7 and 38, and collector well 41 with time and in water samples from the Missouri River with discharge are shown in figure 6 .

Table 3. Quality-assurance/quality-control sample results for water samples from the Missouri River, collector well 41, and a laboratory spike sample.

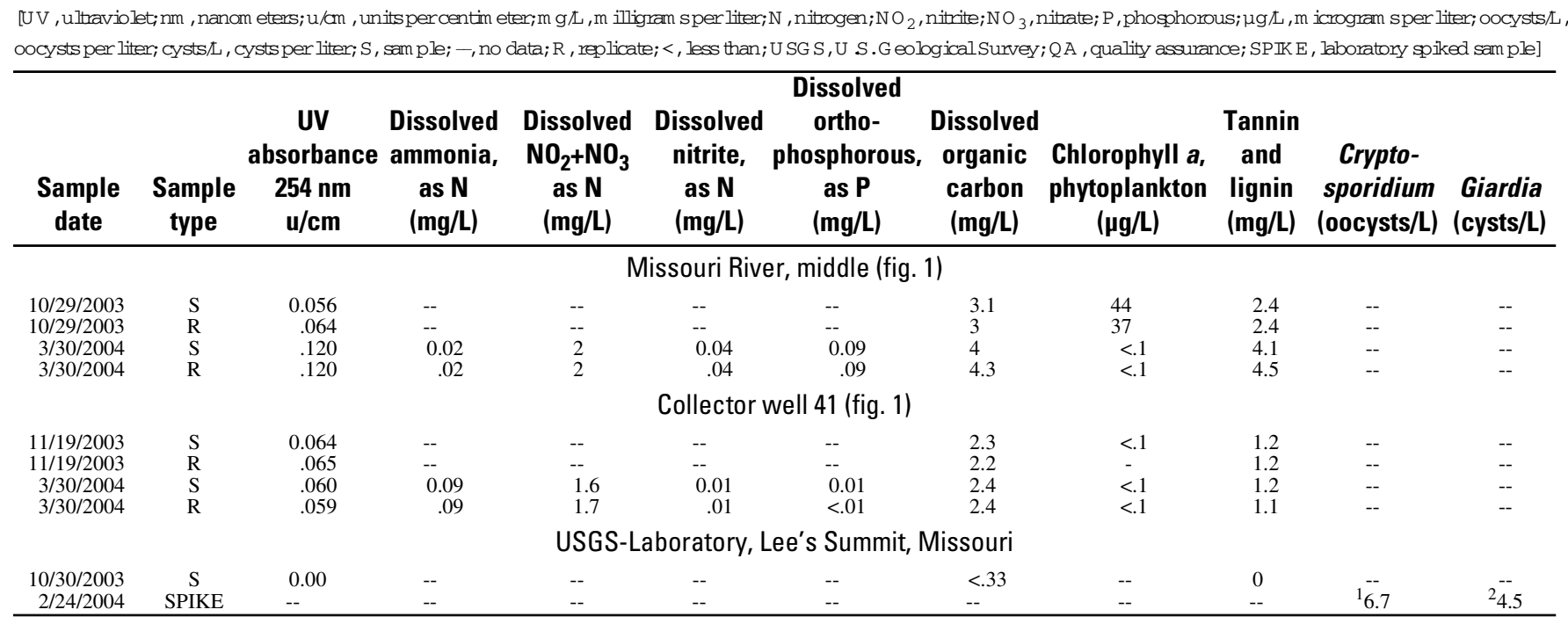

${ }^{1} 67$ percent recovery rate.

${ }^{2} 45$ percent recovery rate. 


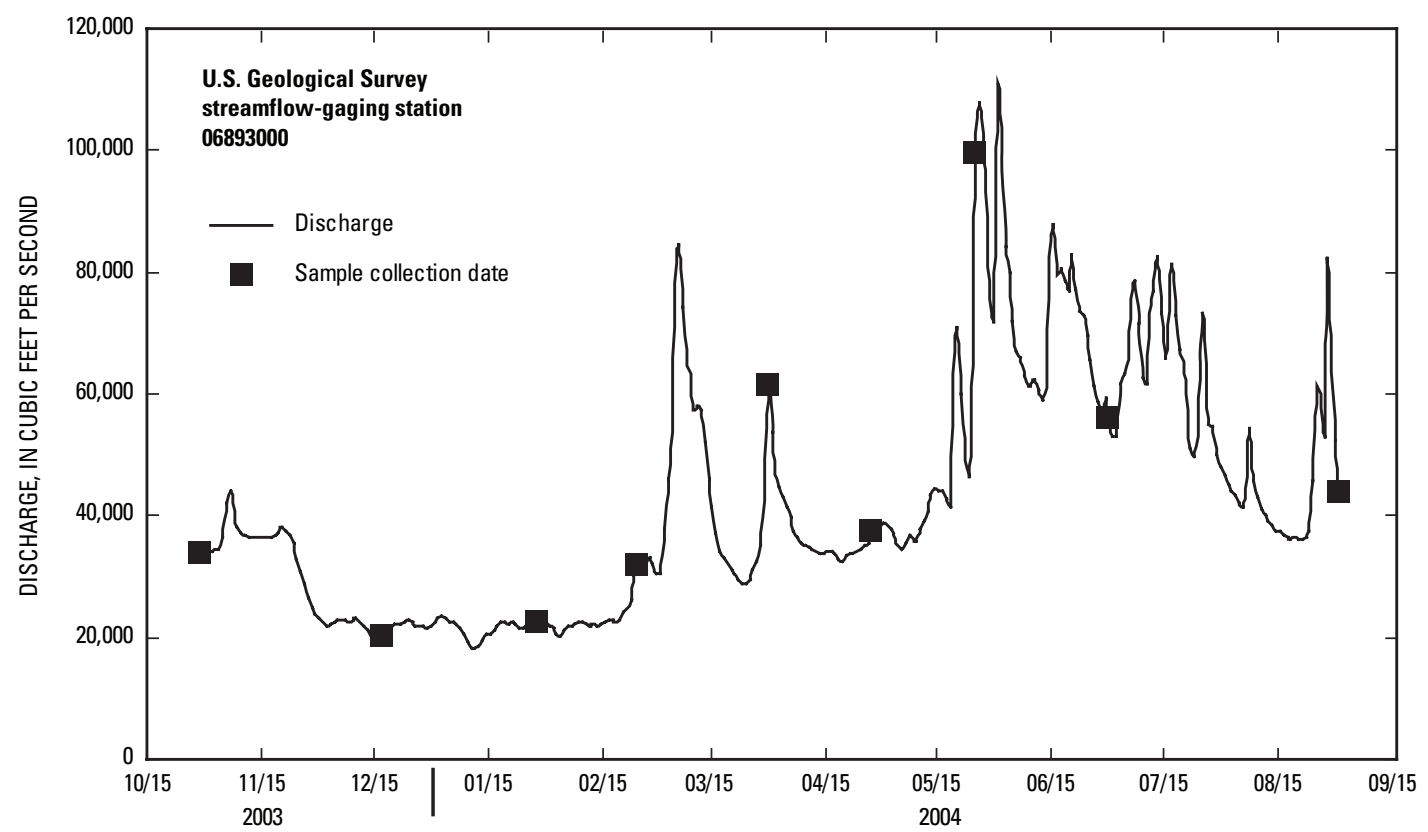

Figure 4. Missouri River sampling dates and discharge at Kansas City, Missouri, October 29, 2003, through August 31, 2004.

Table 4. Missouri River discharge, dissolved oxygen, and physical properties in water samples from the Missouri River, wells 7 and 38 , and collector well 41.

$\left[\mathrm{ft}^{3} / \mathrm{s}\right.$, cubic feet per second; mg/L, milligrams per liter; $\mu \mathrm{S} / \mathrm{cm}$, microsiemens per centimeter at 25 degrees Celsius; ${ }^{\circ} \mathrm{C}$, degrees Celsius; NTU, nephelometric turbidity unit; --, no data;]

\begin{tabular}{|c|c|c|c|c|c|c|}
\hline $\begin{array}{l}\text { Sample } \\
\text { date }\end{array}$ & $\begin{array}{c}\text { Discharge } \\
\left(\mathrm{ft}^{3} / \mathrm{s}\right)\end{array}$ & $\begin{array}{c}\text { Dissolved oxygen } \\
\text { (mg/L) }\end{array}$ & $\begin{array}{c}\mathrm{pH} \\
\text { (standard units) }\end{array}$ & $\begin{array}{c}\text { Specific conductance } \\
\left(\mu \mathrm{S} / \mathrm{cm} \text { at } 25^{\circ} \mathrm{C}\right)\end{array}$ & $\begin{array}{l}\text { Water temperature } \\
\left({ }^{\circ} \mathrm{C}\right)\end{array}$ & $\begin{array}{l}\text { Turbidity } \\
\text { (NTU) }\end{array}$ \\
\hline \multicolumn{7}{|c|}{ Missouri River, middle (fig. 1) } \\
\hline $\begin{array}{r}10 / 29 / 2003 \\
12 / 17 / 2003 \\
1 / 28 / 2004 \\
2 / 24 / 2004 \\
3 / 30 / 2004 \\
4 / 27 / 2004 \\
5 / 25 / 2004 \\
6 / 30 / 2004 \\
8 / 31 / 2004\end{array}$ & $\begin{array}{l}33,900 \\
20,200 \\
22,600 \\
31,800 \\
61,200 \\
37,400 \\
99,600 \\
56,100 \\
43,600\end{array}$ & $\begin{array}{l}10.5 \\
13 \\
12.9 \\
10.8 \\
7.2 \\
9.5 \\
3.94 \\
7 \\
6.3\end{array}$ & $\begin{array}{l}8.5 \\
7.9 \\
8.5 \\
8.2 \\
7.8 \\
8.5 \\
7.8 \\
8.2 \\
8\end{array}$ & $\begin{array}{l}740 \\
876 \\
859 \\
682 \\
562 \\
722 \\
622 \\
666 \\
613\end{array}$ & $\begin{array}{l}15 \\
3.5 \\
0.5 \\
4 \\
14 \\
16.4 \\
22.5 \\
23 \\
26\end{array}$ & $\begin{array}{r}42.0 \\
61.2 \\
18.3 \\
573.0 \\
1,006.0 \\
45.0 \\
1,625.0 \\
240 \\
130\end{array}$ \\
\hline \multicolumn{7}{|c|}{ Missouri River, south (fig. 1) } \\
\hline \multicolumn{7}{|c|}{ Missouri River, north (fig. 1) } \\
\hline \multicolumn{7}{|c|}{ Well 7 (fig. 1) } \\
\hline $\begin{array}{r}11 / 19 / 2003 \\
12 / 17 / 2003 \\
1 / 28 / 2004 \\
2 / 25 / 2004 \\
3 / 31 / 2004 \\
5 / 4 / 2004 \\
5 / 26 / 2004 \\
7 / 13 / 2004 \\
9 / 8 / 2004\end{array}$ & $\begin{array}{l}-- \\
-- \\
-- \\
-- \\
-- \\
-- \\
-- \\
-- \\
--\end{array}$ & $\begin{array}{l}0.3 \\
1.01 \\
1.55 \\
1.35 \\
-- \\
-- \\
1.76 \\
1.7 \\
1\end{array}$ & $\begin{array}{l}7.4 \\
7.4 \\
6.8 \\
7.6 \\
7.6 \\
7.1 \\
7.6 \\
7.7 \\
7.1\end{array}$ & $\begin{array}{l}731 \\
727 \\
704 \\
737 \\
775 \\
778 \\
679 \\
661 \\
624\end{array}$ & $\begin{array}{r}24.5 \\
22.9 \\
19.1 \\
16.8 \\
13.2 \\
12.4 \\
7.8 \\
8.5 \\
13.9\end{array}$ & $\begin{array}{l}6.7 \\
-- \\
-- \\
-- \\
3.28 \\
-- \\
-- \\
--\end{array}$ \\
\hline \multicolumn{7}{|c|}{ Well 38 (fig. 1) } \\
\hline $\begin{array}{r}11 / 5 / 2003 \\
12 / 17 / 2003 \\
1 / 28 / 2004 \\
2 / 25 / 2004 \\
3 / 31 / 2004 \\
5 / 4 / 2004 \\
5 / 26 / 2004 \\
7 / 13 / 2004 \\
9 / 8 / 2004\end{array}$ & $\begin{array}{l}-- \\
-- \\
-- \\
-- \\
-- \\
-- \\
-- \\
-- \\
--\end{array}$ & $\begin{array}{l}0.96 \\
0 \\
.09 \\
.11 \\
.05 \\
.3 \\
.2 \\
0 \\
0\end{array}$ & $\begin{array}{l}7.1 \\
7.5 \\
7.5 \\
7.6 \\
7.6 \\
7.2 \\
7.6 \\
7.7 \\
7.1\end{array}$ & $\begin{array}{l}726 \\
734 \\
721 \\
713 \\
707 \\
776 \\
692 \\
701 \\
707\end{array}$ & $\begin{array}{l}15.1 \\
13.9 \\
14.3 \\
-- \\
17.2 \\
18.4 \\
16.8 \\
13.6 \\
13.1\end{array}$ & $\begin{array}{l}7.06 \\
-- \\
-- \\
-- \\
12.1 \\
-- \\
-- \\
-- \\
--\end{array}$ \\
\hline
\end{tabular}


Table 4. Missouri River discharge, dissolved oxygen, and physical properties in water samples from the Missouri River, wells 7 and 38 , and collector well 41.-Continued

$\left[\mathrm{ft}^{3} / \mathrm{s}\right.$, cubic feet per second; mg/L, milligrams per liter; $\mu \mathrm{S} / \mathrm{cm}$, microsiemens per centimeter at 25 degrees Celsius; ${ }^{\circ} \mathrm{C}$, degrees Celsius; NTU, nephelometric turbidity unit; --, no data;]

\begin{tabular}{|c|c|c|c|c|c|c|}
\hline $\begin{array}{c}\text { Sample } \\
\text { date }\end{array}$ & $\begin{array}{l}\text { Discharge } \\
\left(\mathrm{ft}^{3} / \mathrm{s}\right)\end{array}$ & $\begin{array}{l}\text { Dissolved oxygen } \\
\text { (mg/L) }\end{array}$ & $\begin{array}{c}\mathrm{pH} \\
\text { (standard units) }\end{array}$ & $\begin{array}{l}\text { Specific conductance } \\
\left(\mu \mathrm{S} / \mathrm{cm} \text { at } 25^{\circ} \mathrm{C}\right)\end{array}$ & $\begin{array}{l}\text { Water temperature } \\
\left({ }^{\circ} \mathrm{C}\right)\end{array}$ & $\begin{array}{l}\text { Turbidity } \\
\text { (NTU) }\end{array}$ \\
\hline \multicolumn{7}{|c|}{ Collector well 41 (fig. 1) } \\
\hline $11 / 19 / 2003$ & -- & 0.2 & 7.2 & 711 & 18.3 & 6.67 \\
\hline $12 / 17 / 2003$ & -- & .4 & 7.5 & 752 & 14.4 & \\
\hline $1 / 28 / 2004$ & -- & .31 & 7.5 & 773 & 10.9 & 8 \\
\hline $2 / 25 / 2004$ & -- & .55 & 7.7 & 800 & 8.6 & 2 \\
\hline $3 / 30 / 2004$ & -- & 4.3 & 7.4 & 701 & 8.8 & .81 \\
\hline 5/4/2004 & -- & .3 & 7.1 & 723 & 14.6 & .33 \\
\hline $5 / 26 / 2004$ & -- & .08 & 7.6 & 668 & 16.7 & .6 \\
\hline $7 / 13 / 2004$ & -- & 0 & 7.6 & 622 & 21.6 & -- \\
\hline 9/8/2004 & -- & 0 & 7.3 & 613 & 23.5 & 2.2 \\
\hline
\end{tabular}
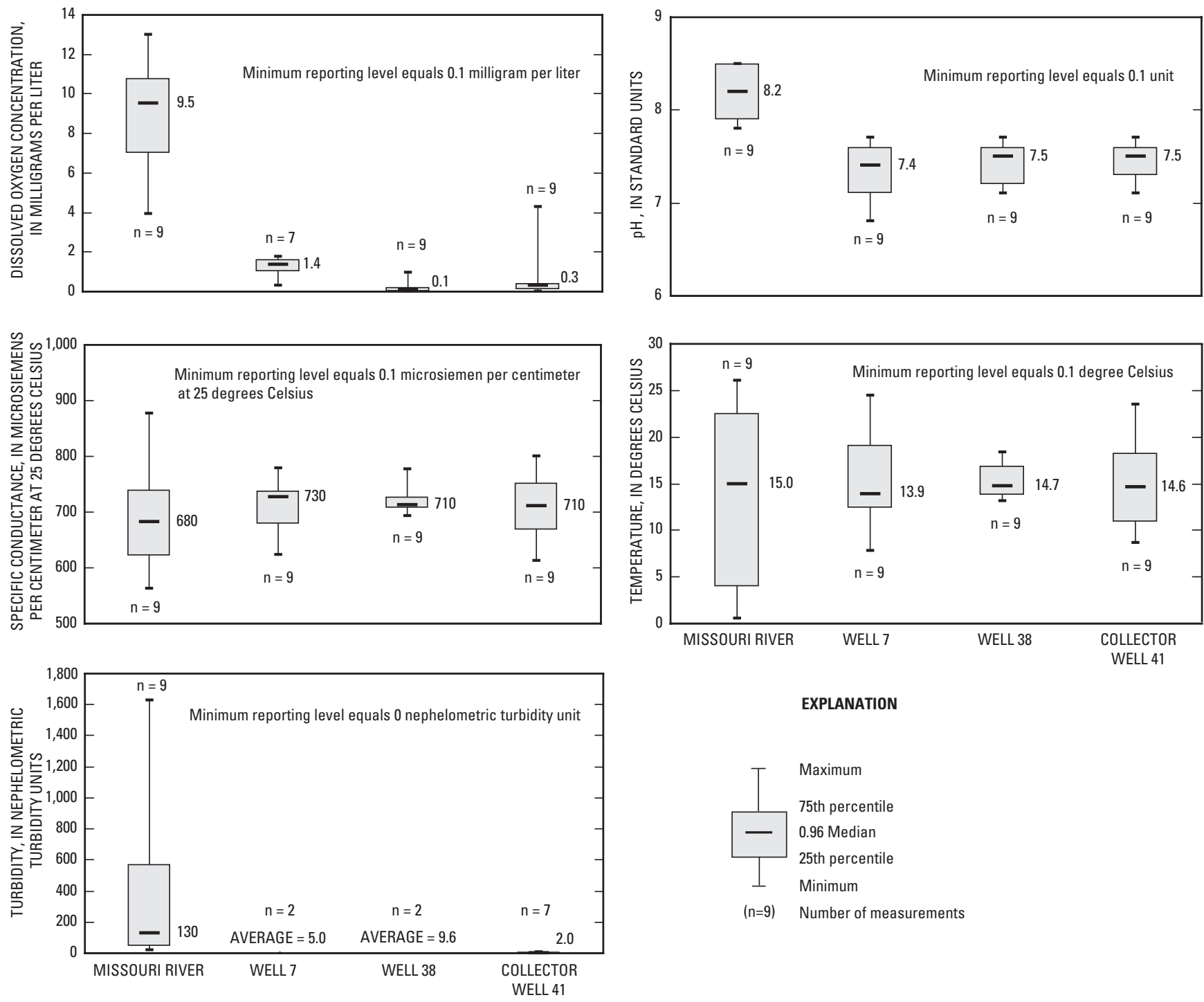

EXPLANATION

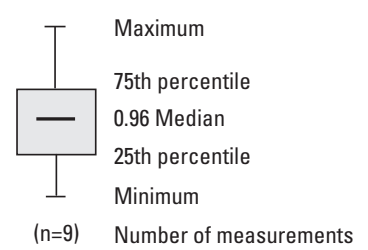

Figure 5. Statistical summary of dissolved oxygen concentrations and selected physical properties in water samples from the Missouri River, wells 7 and 38 , and collector well 41 of the Independence well field. 

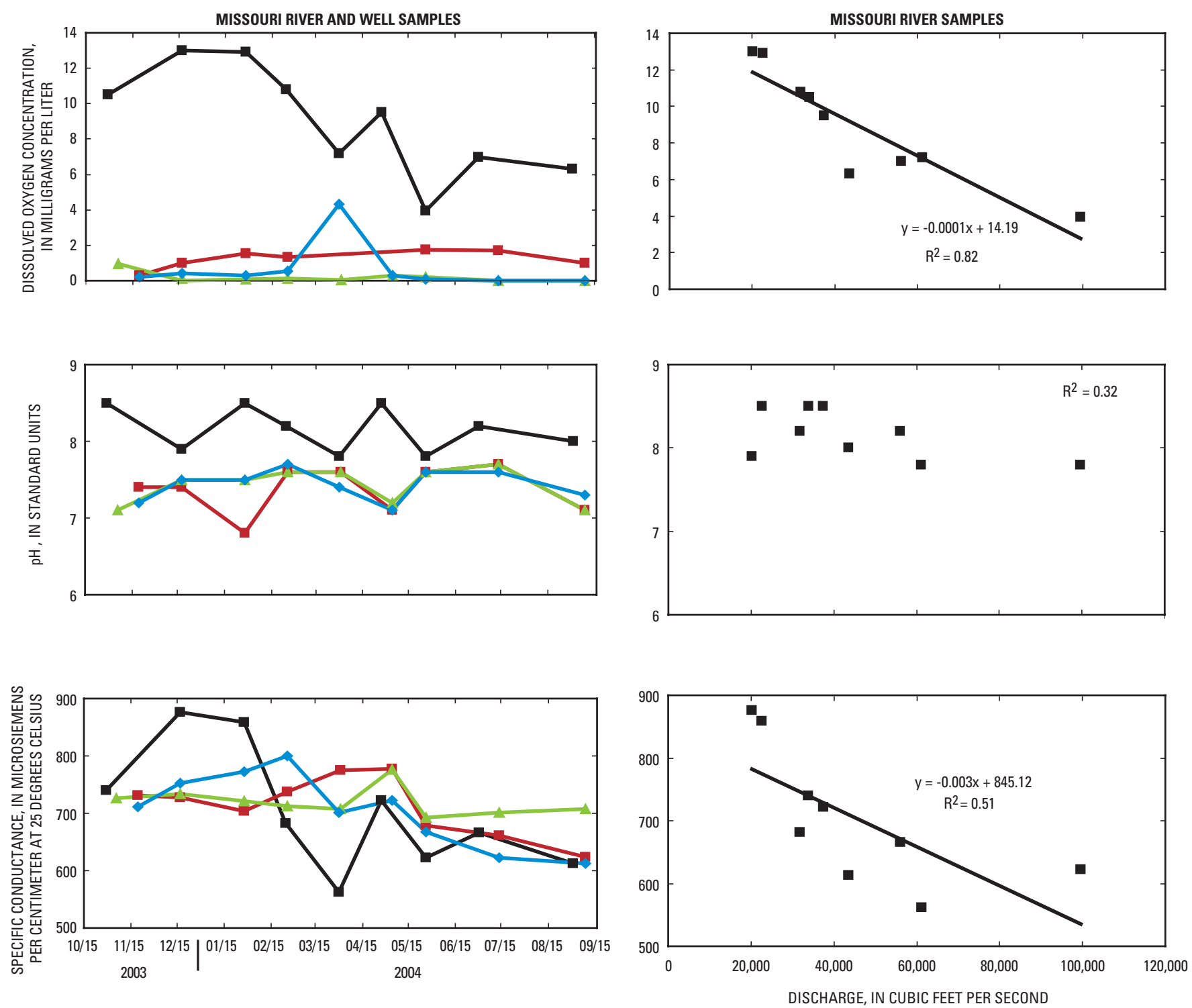

EXPLANATION
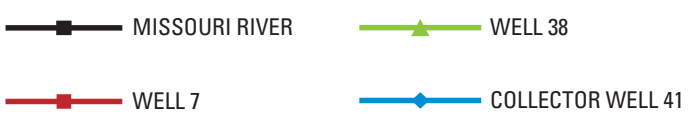

NOTE: Trend lines not plotted for correlation coefficient $\left(R^{2}\right)$ less than 0.5

Figure 6. Dissolved oxygen concentrations and values of physical properties in water samples from the Missouri River, wells 7 and 38 , and collector well 41 with time, and in water samples from the Missouri River with discharge. 

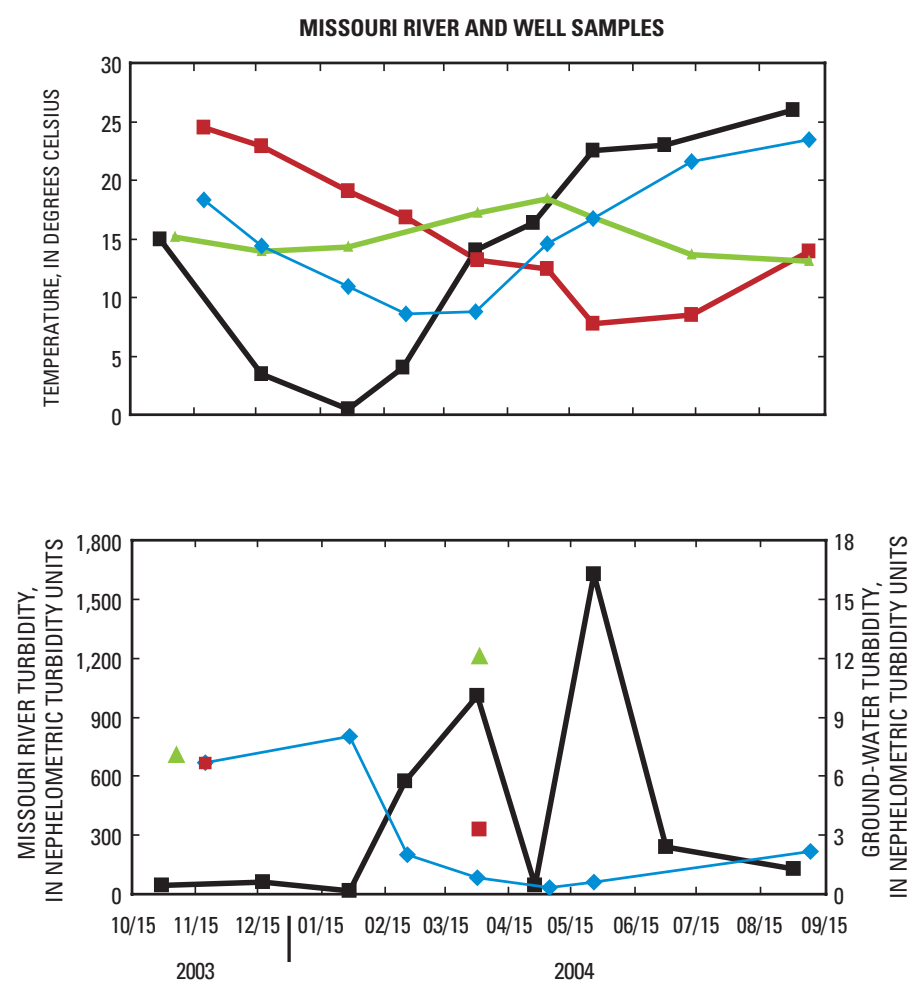

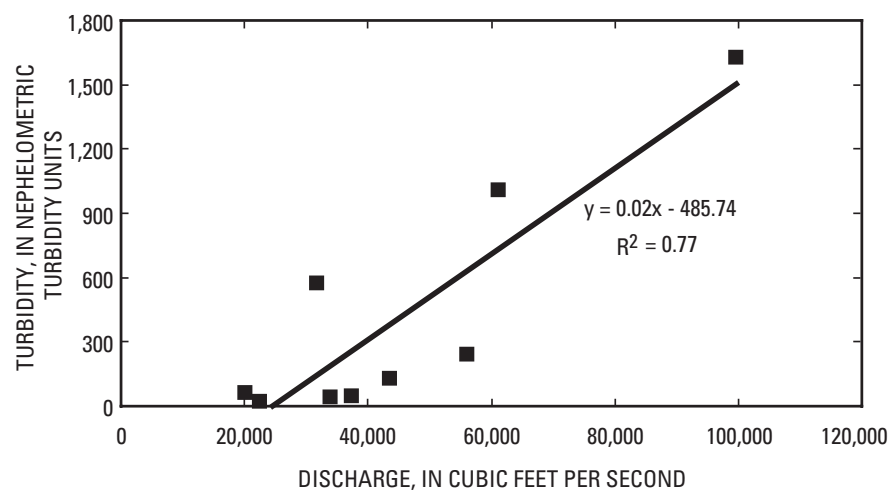

Figure 6. Dissolved oxygen concentrations and values of physical properties in water samples from the Missouri River, wells 7 and 38 , and collector well 41 with time, and in water samples from the Missouri River with discharge-Continued.

The coefficient of determination $\left(\mathrm{R}^{2}\right)$ for the relation between dissolved oxygen and discharge was 0.82 , although the seasonality of dissolved oxygen primarily was caused by changes in water temperature and not discharge. Values for $\mathrm{pH}$ are fairly constant with time in samples from the Missouri River (fig. 6) and in samples from wells (table 4). All wells show similar patterns of increases and decreases of $\mathrm{pH}$, except for the samples collected on January 28, 2004 (table 4), when the pH of the sample from well 7 was lower (6.8) than the $\mathrm{pH}$ in samples from well 38 and collector well 41 (both 7.5). Specific conductance values in Missouri River samples were inversely related to discharge $\left(R^{2}=0.51\right)$. During low river stage much of the flow in the river is derived from upstream reservoir releases and base flow (inflow from ground water). This decrease in specific conductance during high discharge most likely was caused by mixing with rainfall and surface runoff having smaller specific conductance values. Specific conductance remained between 613 and 800 microsiemens per centimeter $(\mu \mathrm{S} / \mathrm{cm})$ in water samples from wells (table 4). Water temperature in the Missouri River followed seasonal air temperatures. Water temperature in wells showed a similar pattern, but increases and decreases in temperature were shifted by time. The water temperature change in samples from wells was caused by river-water temperature changes lagged by the traveltime of ground water from the river to the pumping wells. Seasonal trends were observed in the turbidity in water samples from the Missouri River and collector well 41 . The turbidity in the river was related positively to discharge, $\mathrm{R}^{2}=0.77$. This positive relation most likely was caused by the inflow of sediment and organic material during runoff events and may indicate that both suspended sediment concentration and turbidity might be estimated from discharge. Only two samples each for turbidity were collected from well 7 and well 38 .

Organic material and organic indicators measured in water samples during this study include dissolved organic carbon (DOC), ultraviolet absorbance at 254 nanometers (nm) (UV254, used to indirectly measure the aromatic carbon content which is a precursor to disinfection by-product formation), specific ultraviolet absorbance (SUVA, UV254 divided by the dissolved organic carbon concentration and multiplied by 100), chlorophyll $a$, and tannin and lignin. Results of analyses for organic material and organic indicators are listed in table 5 and summarized in figure 7. Median values of DOC, UV254, chlorophyll $a$, and tannin and lignin are larger in samples from the Missouri River than in samples from wells 7 and 38, and collector well 41 (fig. 7). The median for SUVA was slightly smaller in samples from the Missouri River than in samples from wells 7 and 38 and collector well 41 .

Levels of organic material and organic indicators in water samples from the Missouri River, wells 7 and 38, and collector well 41 with time and in water samples from the Missouri River with discharge are shown in figure 8. Dissolved organic carbon 
Table 5. Organic material and organic indicators in water samples from the Missouri River, wells 7 and 38 , and collector well 41.

$[\mathrm{mg} / \mathrm{L}$, milligrams per liter; $\mathrm{nm}$, nanometers; $\mathrm{u} / \mathrm{cm}$, units per centimeter; $\mu \mathrm{g} / \mathrm{L}$, micrograms per liter; ,-- no data; $<$, less than]

\begin{tabular}{|c|c|c|c|c|}
\hline Sample date & $\begin{array}{c}\text { Dissolved } \\
\text { organic } \\
\text { carbon } \\
\text { (mg/L) }\end{array}$ & $\begin{array}{c}\text { Ultraviolet } \\
\text { absorbance } \\
254 \mathrm{~nm} \\
\text { (u/cm) }\end{array}$ & $\begin{array}{c}\text { Chlorophyll } a, \\
\text { phytoplankton, } \\
(\mu \mathrm{g} / \mathrm{L})\end{array}$ & $\begin{array}{c}\text { Tannin and lignin } \\
\text { (mg/L) }\end{array}$ \\
\hline \multicolumn{5}{|c|}{ Missouri River, middle (fig. 1) } \\
\hline $\begin{array}{r}10 / 29 / 2003 \\
12 / 17 / 2003 \\
1 / 28 / 2004 \\
2 / 24 / 2004 \\
3 / 30 / 2004 \\
4 / 27 / 2004 \\
5 / 25 / 2004 \\
6 / 30 / 2004 \\
8 / 31 / 2004\end{array}$ & $\begin{array}{l}3.1 \\
2.9 \\
3.6 \\
3.9 \\
4.0 \\
3.0 \\
3.2 \\
3.8 \\
4.1\end{array}$ & $\begin{array}{r}0.056 \\
.063 \\
.063 \\
.091 \\
.120 \\
.068 \\
.102 \\
.087 \\
.108\end{array}$ & $\begin{array}{c}44 \\
13 \\
8.9 \\
-- \\
<.1 \\
-- \\
<.1 \\
29 \\
--\end{array}$ & $\begin{array}{r}2.4 \\
2.2 \\
2.1 \\
3.5 \\
4.1 \\
1.9 \\
9.4 \\
.6\end{array}$ \\
\hline \multicolumn{5}{|c|}{ Well 7 (fig. 1) } \\
\hline $\begin{array}{r}11 / 19 / 2003 \\
12 / 17 / 2003 \\
1 / 28 / 2004 \\
2 / 25 / 2004 \\
3 / 31 / 2004 \\
5 / 4 / 2004 \\
5 / 26 / 2004 \\
7 / 13 / 2004 \\
9 / 8 / 2004\end{array}$ & $\begin{array}{l}2.6 \\
2.5 \\
2.5 \\
2.3 \\
1.9 \\
1.9 \\
1.6 \\
2.3 \\
2.5\end{array}$ & $\begin{array}{r}0.093 \\
.101 \\
.055 \\
.052 \\
.039 \\
.046 \\
.043 \\
.041 \\
.079\end{array}$ & $\begin{array}{l}<0.1 \\
-- \\
-- \\
-- \\
<.1 \\
-- \\
-- \\
<.1 \\
--\end{array}$ & $\begin{array}{l}1.5 \\
-- \\
-- \\
-- \\
1.5 \\
1.5 \\
-- \\
1.5 \\
--\end{array}$ \\
\hline \multicolumn{5}{|c|}{ Well 38 (fig. 1) } \\
\hline $\begin{array}{r}11 / 5 / 2003 \\
12 / 17 / 2003 \\
1 / 28 / 2004 \\
2 / 25 / 2004 \\
3 / 31 / 2004 \\
5 / 4 / 2004 \\
5 / 26 / 2004 \\
7 / 13 / 2004 \\
9 / 8 / 2004\end{array}$ & $\begin{array}{l}2.4 \\
2.5 \\
2.7 \\
2.5 \\
2.4 \\
2.3 \\
2.0 \\
2.8 \\
2.5\end{array}$ & $\begin{array}{l}0.057 \\
.102 \\
.056 \\
.058 \\
.060 \\
.057 \\
.067 \\
.061 \\
.074\end{array}$ & $\begin{array}{l}<0.1 \\
-- \\
-- \\
-- \\
<.1 \\
-- \\
-- \\
<.1 \\
--\end{array}$ & $\begin{array}{l}2.0 \\
-- \\
-- \\
-- \\
2.1 \\
2.1 \\
-- \\
1.5 \\
--\end{array}$ \\
\hline \multicolumn{5}{|c|}{ Collector well 41 (fig. 1) } \\
\hline $\begin{array}{r}11 / 19 / 2003 \\
12 / 17 / 2003 \\
1 / 28 / 2004 \\
2 / 25 / 2004 \\
3 / 30 / 2004 \\
5 / 4 / 2004 \\
5 / 26 / 2004 \\
7 / 13 / 2004 \\
9 / 8 / 2004\end{array}$ & $\begin{array}{l}2.3 \\
2.3 \\
2.7 \\
2.3 \\
2.4 \\
2.1 \\
2.0 \\
2.4 \\
2.4\end{array}$ & $\begin{array}{r}0.064 \\
.075 \\
.047 \\
.056 \\
.060 \\
.060 \\
.054 \\
.058 \\
.080\end{array}$ & $\begin{array}{l}<0.1 \\
<.1 \\
<.1 \\
-- \\
<.1 \\
-- \\
<.1 \\
<.1 \\
--\end{array}$ & $\begin{array}{r}1.2 \\
1.1 \\
1.4 \\
0.5 \\
1.2 \\
1.4 \\
1.0 \\
.9 \\
--\end{array}$ \\
\hline
\end{tabular}

remained fairly constant [about 3 to 4 milligrams per liter (mg/L)] for all Missouri River samples, and were not closely related to discharge. Dissolved organic carbon concentrations in well samples remained fairly constant (between 1.6 and 2.8 $\mathrm{mg} / \mathrm{L}$ ). The variation of SUVA in water samples from the Missouri River and wells was similar to the pattern for UV254. The $\mathrm{R}^{2}$ value for the relation between SUVA in water samples from the Missouri River and discharge was 0.70. Low chlorophyll $a$ most likely was caused by high turbidity that decreased algal growth. Chlorophyll $a$ was undetected in all well samples. Tannin and lignin in water samples from the Missouri River were variable (between 0.6 and $9.4 \mathrm{mg} / \mathrm{L}$; table 6). Tannin and lignin was constant in samples from well $7(1.5 \mathrm{mg} / \mathrm{L})$, and fairly constant in samples from well 38 (between 1.5 and 2.1 $\mathrm{mg} / \mathrm{L}$ ) and in samples from collector well 41 (between 0.5 and $1.4 \mathrm{mg} / \mathrm{L}$; table 5). The $\mathrm{R}^{2}$ value for the relation between tannin and lignin in water samples from the Missouri River and discharge was 0.62 .

Nutrients measured in water samples during this study include dissolved ammonia-nitrogen (hereafter referred to as dis- solved ammonia), dissolved nitrite-plus-nitrate-nitrogen (hereafter referred to as dissolved nitrite plus nitrate), dissolved nitritenitrogen (hereafter referred to as dissolved nitrite), and dissolved orthophosphorous-phosphorous (hereafter referred to as dissolved orthophosphorous). Dissolved nitrate was calculated by subtracting the dissolved nitrite concentration from the dissolved nitrite plus nitrate concentration for the same samples. Results of analyses for nutrients are listed in table 6 and summarized in figure 9. Median values for dissolved nitrite plus nitrate, dissolved nitrate, and dissolved orthophosphorous are highest for samples from the Missouri River. Median values of dissolved ammonia are highest for samples from well 38. Dissolved nitrite and dissolved nitrate were not detected in samples from wells 7 and 38 .

Concentrations of selected nutrients in water samples from the Missouri River, wells 7 and 38, and collector well 41 with time and in water samples from the Missouri River with discharge are shown in figure 10. Dissolved ammonia ranged from 0.02 to $0.35 \mathrm{mg} / \mathrm{L}$ in water samples from the Missouri River, from 0.05 to $0.07 \mathrm{mg} / \mathrm{L}$ in samples from well 7 , from 0.19 to $0.22 \mathrm{mg} / \mathrm{L}$ in samples from well 38 , and from 0.06 to 0.10 

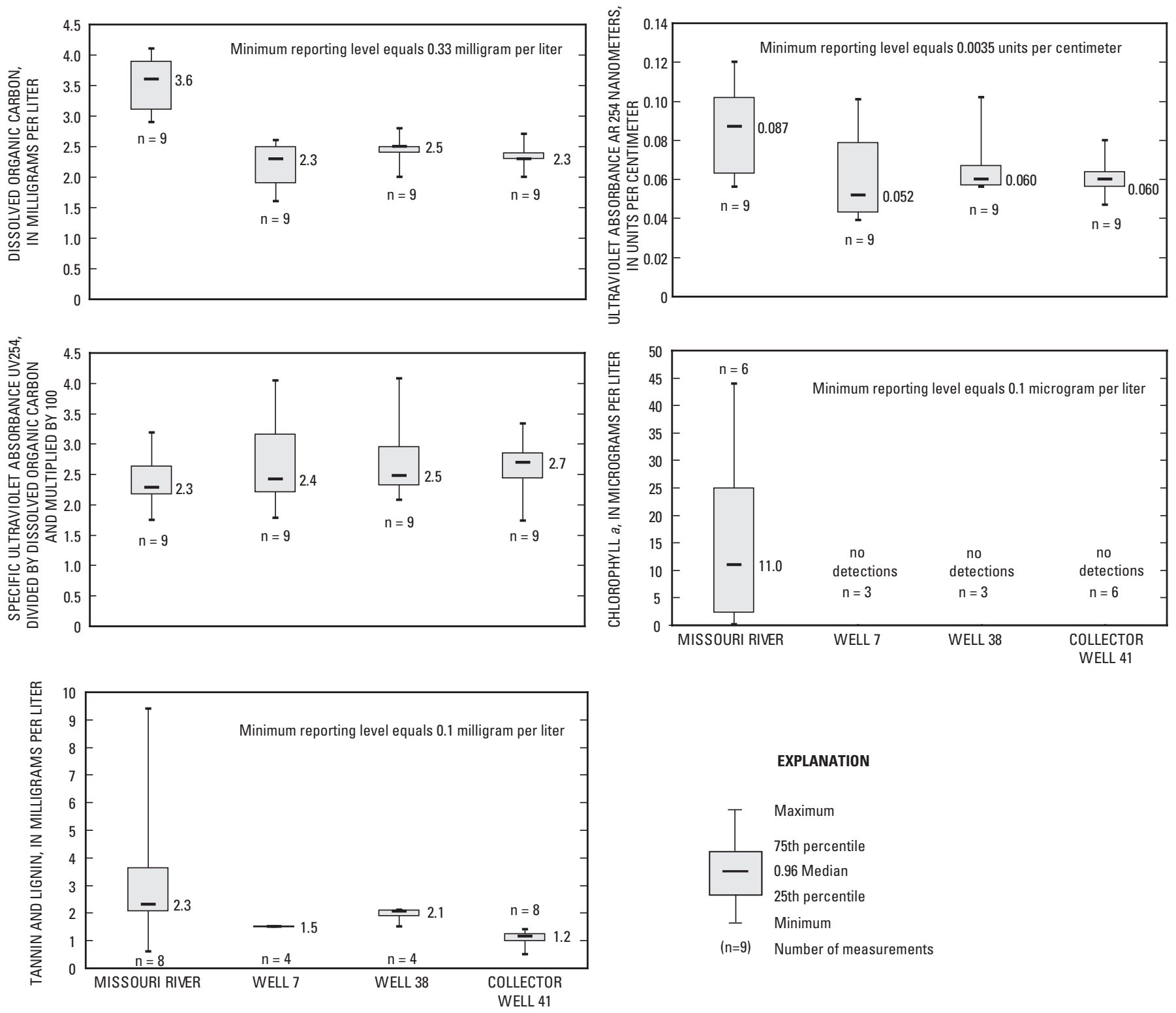

Figure 7. Statistical summary of selected organic material and organic indicators in water samples from the Missouri River, wells 7 and 38 , and collector well 41 of the Independence well field.

$\mathrm{mg} / \mathrm{L}$ in samples from collector well 41. Dissolved nitrate values in water samples from the Missouri River ranged from 0.62 to $2.48 \mathrm{mg} / \mathrm{L}$ and were related positively to discharge $\left(\mathrm{R}^{2}\right.$ $=0.43$ ). Dissolved nitrate was below detection in all six samples from wells 7 and 38, and ranged from 0.06 to $1.59 \mathrm{mg} / \mathrm{L}$ in water samples from collector well 41 . Dissolved orthophosphorous values in water samples from the Missouri River ranged from 0.04 to $0.12 \mathrm{mg} / \mathrm{L}$, from below detection to $0.03 \mathrm{mg} / \mathrm{L}$ in well 7 , from below detection to $0.04 \mathrm{mg} / \mathrm{l}$ in samples from well 38 , and from below detection to $0.03 \mathrm{mg} / \mathrm{L}$ in samples from collector well 41.

Results of analyses for total coliform bacteria, Cryptosporidium, Giardia, and total culturable viruses are listed in table
7. The small number of detections of Cryptosporidium and Giardia in the Missouri River prevented a statistical summary calculation. Total coliform bacteria and total culturable viruses are summarized in figure 11. Total coliform bacteria, Cryptosporidium, Giardia, and total culturable viruses are not uniformly distributed in river or ground water. The irregular distribution of these organisms in water may cause a negative result in a sample collected from one location, but a positive result in a sample from the same location at a slightly different time, or from another nearby location. The minimum reporting level for Cryptosporidium, Giardia, and total culturable virus analyses changed based on the nature of the water sample. In samples from the Missouri River, larger turbidity values were associated 

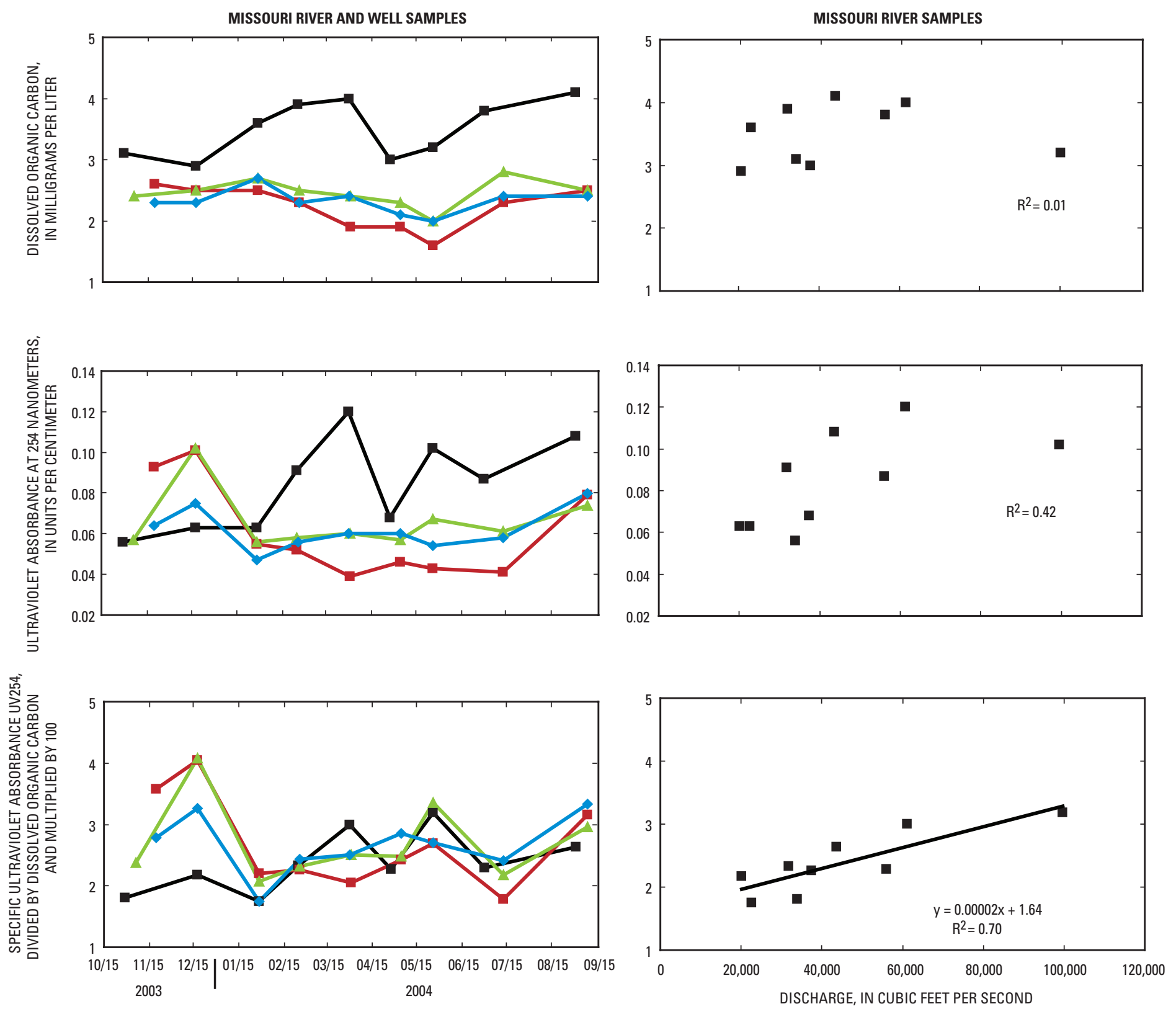

EXPLANATION
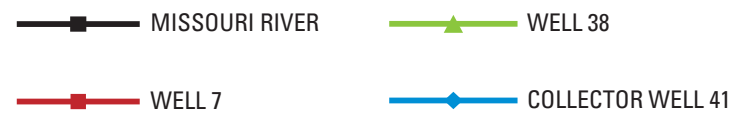

NOTE: Trend lines not plotted for correlation coefficient $\left(R^{2}\right)$ less than 0.5

Figure 8. Organic material concentrations and values of organic indicators in water samples from the Missouri River, wells 7 and 38 , and collector well 41 with time, and in water samples from the Missouri River with discharge. 

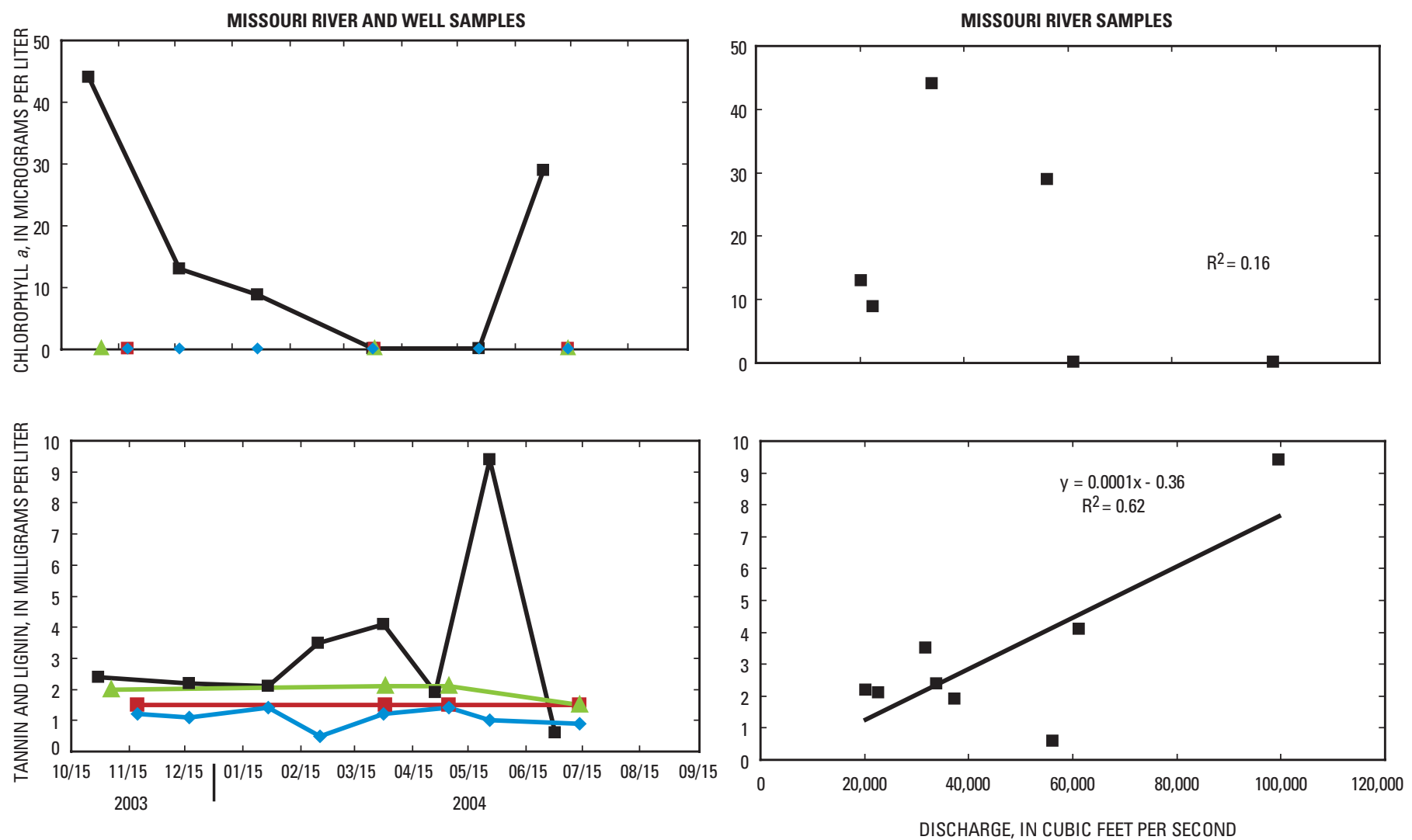

Figure 8. Organic material concentrations and values of organic indicators in water samples from the Missouri River, wells 7 and 38 , and collector well 41 with time, and in water samples from the Missouri River with discharge-Continued.

Table 6. Nutrients in water samples from the Missouri River, wells 7 and 38, and collector well 41.

[N, nitrogen; mg/L, milligrams per liter; $\mathrm{NO}_{2}$, nitrite; $\mathrm{NO}_{3}$, nitrate; $\mathrm{P}$, phosphorous; <, less than]

\begin{tabular}{|c|c|c|c|c|c|}
\hline $\begin{array}{c}\text { Sample } \\
\text { date }\end{array}$ & $\begin{array}{c}\text { Dissolved } \\
\text { ammonia, } \\
\text { as N } \\
(\mathrm{mg} / \mathrm{L})\end{array}$ & $\begin{array}{c}\text { Dissolved } \\
\mathrm{NO}_{2}+\mathrm{NO}_{3} \\
\text { as } \mathrm{N} \\
\text { (mg/L) }\end{array}$ & $\begin{array}{c}\text { Dissolved } \\
\mathrm{NO}_{2} \text {, as N } \\
(\mathrm{mg} / \mathrm{L})\end{array}$ & $\begin{array}{c}\text { Dissolved } \\
\mathrm{NO}_{3} \text {, as N } \\
(\mathrm{mg} / \mathrm{L})\end{array}$ & $\begin{array}{c}\text { Dissolved } \\
\text { orthophosphorous. } \\
\text { as } P \\
\text { (mg/L) }\end{array}$ \\
\hline \multicolumn{6}{|c|}{ Missouri River, middle (fig. 1) } \\
\hline $\begin{array}{l}1 / 28 / 2004 \\
2 / 24 / 2004 \\
3 / 30 / 2004 \\
4 / 27 / 2004 \\
5 / 25 / 2004 \\
6 / 30 / 2004 \\
8 / 31 / 2004\end{array}$ & $\begin{array}{l}0.35 \\
.21 \\
.02 \\
.08 \\
.08 \\
.03 \\
.12\end{array}$ & $\begin{array}{l}0.97 \\
1.4 \\
2.0 \\
.68 \\
2.2 \\
2.5 \\
.64\end{array}$ & $\begin{array}{l}0.020 \\
.020 \\
.040 \\
.010 \\
.090 \\
.020 \\
.020\end{array}$ & $\begin{array}{l}0.95 \\
1.38 \\
1.96 \\
.67 \\
1.3 \\
2.48 \\
.62\end{array}$ & $\begin{array}{l}0.12 \\
.07 \\
.09 \\
.04 \\
.07 \\
.12 \\
.11\end{array}$ \\
\hline \multicolumn{6}{|c|}{ Well 7 (fig. 1) } \\
\hline $\begin{array}{r}3 / 31 / 2004 \\
5 / 4 / 2004 \\
5 / 26 / 2004 \\
7 / 13 / 2004 \\
9 / 8 / 2004\end{array}$ & $\begin{array}{l}0.07 \\
.06 \\
.06 \\
.05 \\
.05\end{array}$ & $\begin{array}{l}<0.02 \\
<.02 \\
<.02 \\
<.02 \\
<.06\end{array}$ & $\begin{array}{r}<0.010 \\
<.010 \\
<.010 \\
<.010 \\
<.008\end{array}$ & $\begin{array}{l}<0.01 \\
<.01 \\
<.01 \\
<.01 \\
<.052\end{array}$ & $\begin{array}{r}<0.01 \\
<.01 \\
<.01 \\
.03 \\
.02\end{array}$ \\
\hline \multicolumn{6}{|c|}{ Well 38 (fig. 1) } \\
\hline $\begin{array}{r}3 / 31 / 2004 \\
5 / 4 / 2004 \\
5 / 26 / 2004 \\
7 / 13 / 2004 \\
9 / 8 / 2004\end{array}$ & $\begin{array}{r}0.22 \\
.20 \\
.20 \\
.22 \\
.19\end{array}$ & $\begin{array}{l}<0.02 \\
<.02 \\
<.02 \\
<.02 \\
<.06\end{array}$ & $\begin{array}{r}<0.010 \\
<.010 \\
<.010 \\
<.010 \\
<.008\end{array}$ & $\begin{array}{l}<0.01 \\
<.01 \\
<.01 \\
<.01 \\
<.052\end{array}$ & $\begin{array}{r}<0.01 \\
<.01 \\
<.01 \\
.04 \\
.03\end{array}$ \\
\hline \multicolumn{6}{|c|}{ Collector well 41 (fig. 1) } \\
\hline $\begin{array}{l}1 / 28 / 2004 \\
2 / 25 / 2004 \\
3 / 30 / 2004 \\
5 / 4 / 2004 \\
5 / 26 / 2004 \\
7 / 13 / 2004 \\
9 / 8 / 2004\end{array}$ & $\begin{array}{l}0.10 \\
.09 \\
.09 \\
.07 \\
.07 \\
.08 \\
.06\end{array}$ & $\begin{array}{c}0.66 \\
.7 \\
1.6 \\
.54 \\
.7 \\
.83 \\
.08\end{array}$ & $\begin{array}{r}0.010 \\
<.010 \\
.010 \\
.020 \\
.020 \\
.000 \\
.019\end{array}$ & $\begin{array}{l}0.65 \\
.69 \\
1.59 \\
.52 \\
.68 \\
.8 \\
.061\end{array}$ & $\begin{array}{r}0.02 \\
.01 \\
.01 \\
<.01 \\
<.01 \\
.03 \\
.02\end{array}$ \\
\hline
\end{tabular}



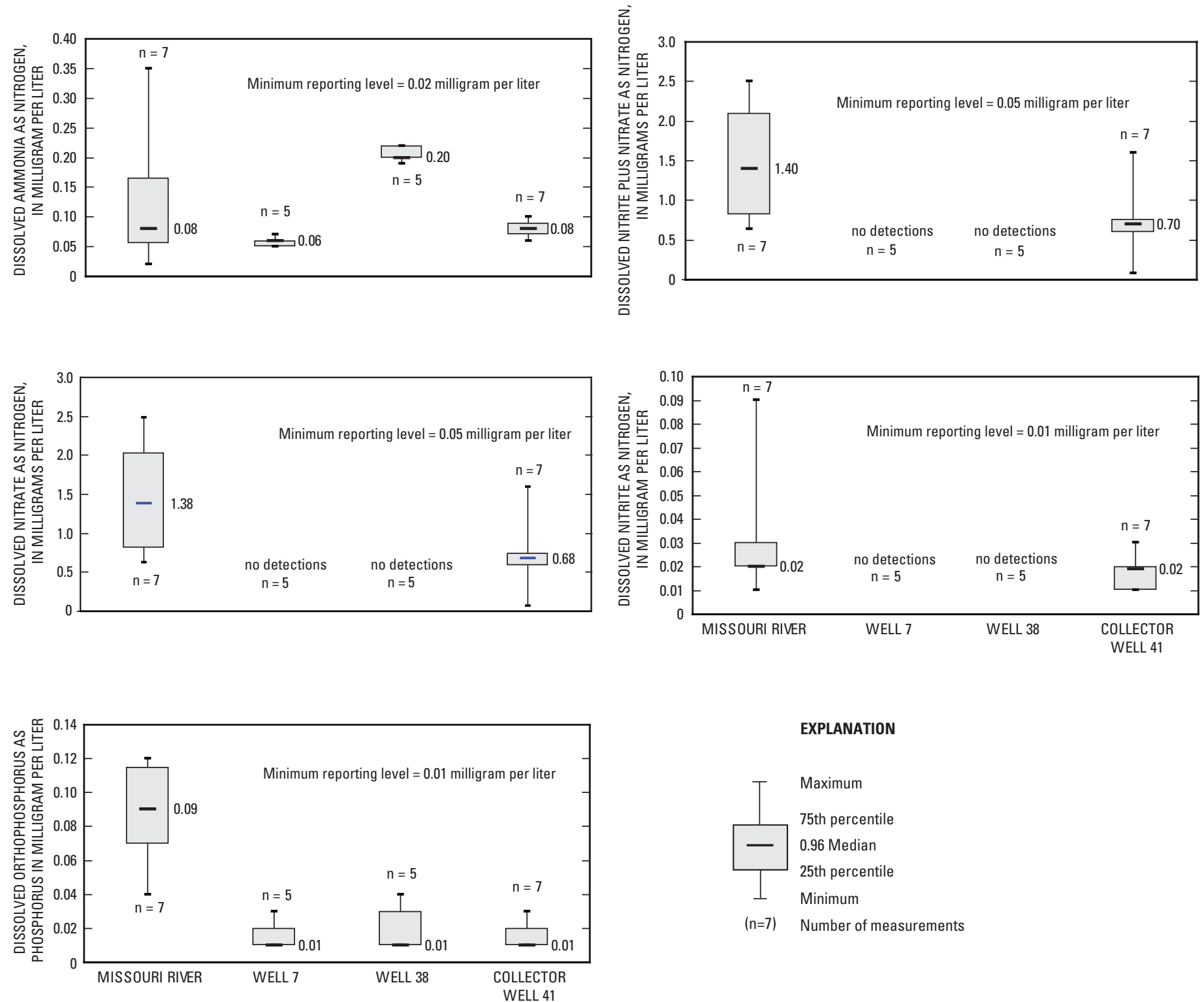

Figure 9. Statistical summary of selected nutrients in water samples from the Missouri River, wells 7 and 38 , and collector well 41 of the Independence well field.

with larger minimum detection levels for Cryptosporidium and Giardia (tables 4 and 7). For Cryptosporidium, Giardia, and total culturable virus, the larger the volume of water sampled (up to the maximum for the analysis) reduced the minimum detection level; therefore, the minimum reporting level for one sample may be less than the minimum reporting level for another sample.

Changes with time and discharge of total coliform bacteria, Cryptosporidium, Giardia, and total culturable viruses in Missouri River water samples are shown in figure 12. Total coliform bacteria densities in water samples from the Missouri River ranged from 4,200 to $80,000 \mathrm{col} / 100 \mathrm{~mL}$ (colonies per 100 milliliters). Cryptosporidium was detected only once in the Missouri River on August 31, 2004. Giardia was detected in four out of nine samples, and did not show any seasonal trends. Total culturable viruses in Missouri River water samples ranged from 6.02 to $48.6 \mathrm{MPN} / \mathrm{L}$ (most probable number per liter). No strong correlations were found between bacteria, protozoa, and viruses in water samples from the Missouri River and discharge, most likely because of the small data set. Bacteria, protozoa, and viruses were not detected in samples from wells 7 and 38 and collector well 41, indicating effective removal of these organisms by riverbank filtration.

Formation potentials for haloacetic acids and trihalomethane compounds were analyzed for six samples each from the Missouri River, wells 7 and 38, and collector well 41 between October 29, 2003, and April 29, 2004. Haloacetic acid forma- 

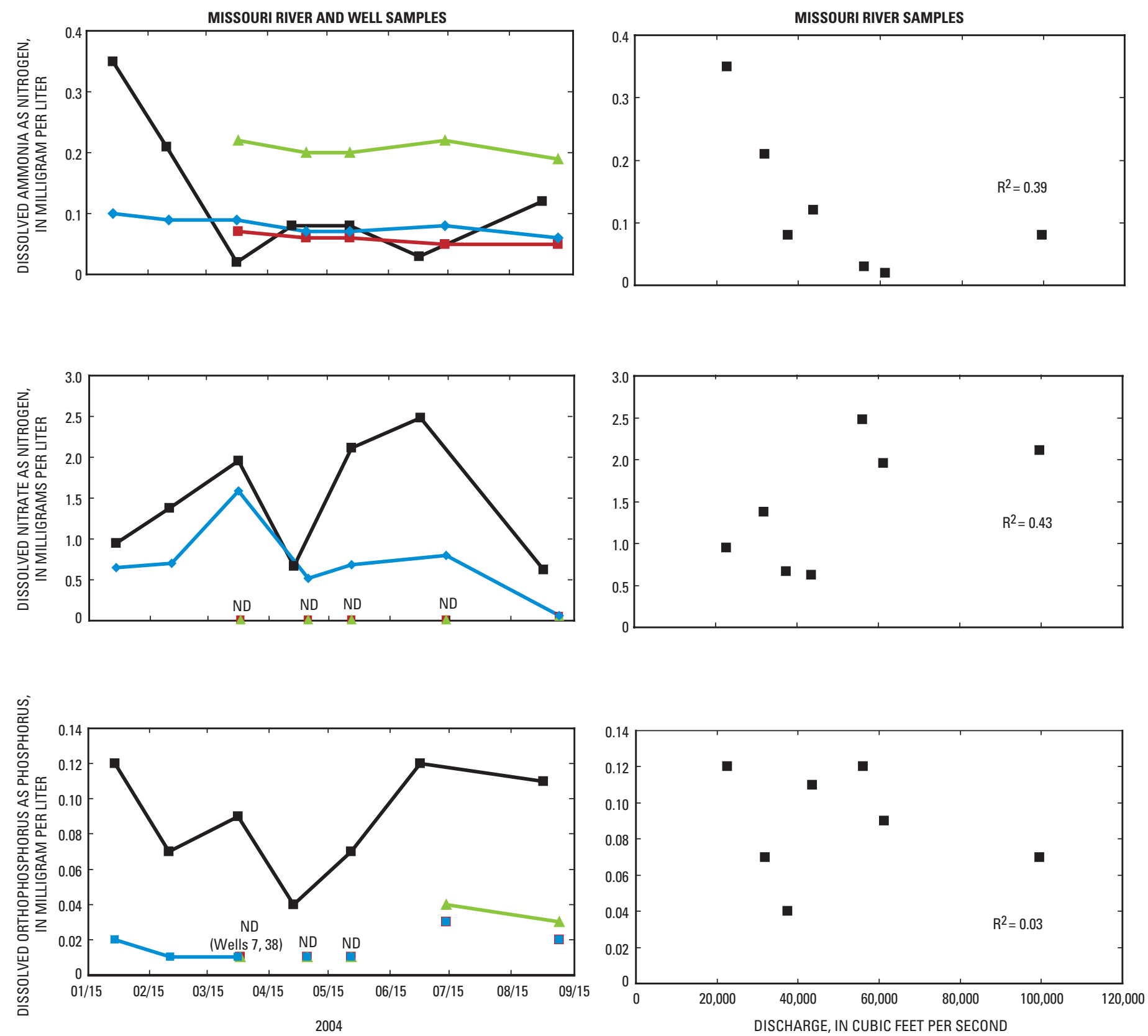

EXPLANATION
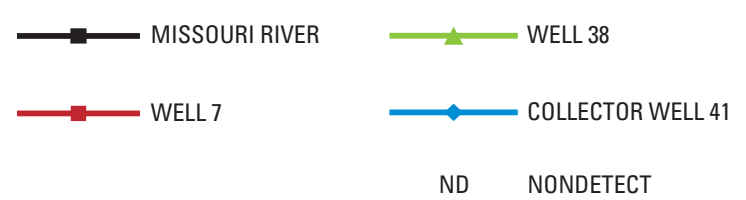

NOTE: Trend lines not plotted for correlation coefficient $\left(\mathrm{R}^{2}\right)$ less than 0.5

Figure 10. Nutrient concentrations in water samples from the Missouri River, wells 7 and 38, and collector well 41 with time, and in water samples from the Missouri River with discharge. 
Table 7. Total coliform bacteria, Cryptosporidium, Giardia, and total culturable viruses in water samples from the Missouri River, wells 7 and 38, and collector well 41.

[col/100 mL, colonies per 100 milliliters; cysts/L, cysts per liter; oocysts/L, oocysts per liter; MPN/100 L, most probable number per 100 liters; <, less than; --, no data]

\begin{tabular}{|c|c|c|c|c|}
\hline Sample date & $\begin{array}{c}\text { Total coliform bacteria, } \\
\text { col/100 mL }\end{array}$ & $\begin{array}{c}\text { Cryptosporidium, } \\
\text { oocysts/L }\end{array}$ & $\begin{array}{l}\text { Giardia, } \\
\text { cysts/L }\end{array}$ & $\begin{array}{c}\text { Total culturable virus, } \\
\text { MPN/100 L }\end{array}$ \\
\hline \multicolumn{5}{|c|}{ Missouri River, middle (fig. 1) } \\
\hline $\begin{array}{r}10 / 29 / 2003 \\
12 / 17 / 2003 \\
1 / 28 / 2004 \\
2 / 24 / 2004 \\
3 / 30 / 2004 \\
4 / 27 / 2004 \\
5 / 25 / 2004 \\
6 / 30 / 2004 \\
8 / 31 / 2004\end{array}$ & $\begin{array}{r}180,000 \\
1_{30,000} \\
37,000 \\
52,000 \\
28,000 \\
46,000 \\
-- \\
4,200 \\
--\end{array}$ & $\begin{aligned} &<<.095 \\
&<.091 \\
&<.091 \\
&<.76 \\
&<.45 \\
&<.093 \\
&<.55 \\
&<.19 \\
& \quad .14\end{aligned}$ & $\begin{array}{l}0.19 \\
.091 \\
.27 \\
<.76 \\
<.45 \\
.093 \\
<.55 \\
<.19 \\
<.14\end{array}$ & $\begin{array}{c}24.1 \\
-- \\
-- \\
44 \\
48.6 \\
21 \\
6.02 \\
-- \\
10.1\end{array}$ \\
\hline \multicolumn{5}{|c|}{ Well 7 (fig. 1) } \\
\hline $\begin{array}{r}11 / 19 / 2003 \\
12 / 17 / 2003 \\
3 / 31 / 2004 \\
7 / 13 / 2004 \\
9 / 8 / 2004\end{array}$ & $\begin{array}{l}1_{0} \\
1_{0} \\
-- \\
-- \\
0\end{array}$ & $\begin{array}{l}<0.004 \\
-- \\
<.002 \\
<.003 \\
--\end{array}$ & $\begin{array}{l}<0.004 \\
-- \\
<.002 \\
<.003 \\
--\end{array}$ & $\begin{array}{l}<10 \\
-- \\
<3.33 \\
<.11 \\
--\end{array}$ \\
\hline \multicolumn{5}{|c|}{ Well 38 (fig. 1) } \\
\hline $\begin{array}{r}11 / 5 / 2003 \\
12 / 17 / 2003 \\
3 / 31 / 2004 \\
7 / 13 / 2004 \\
9 / 8 / 2004\end{array}$ & $\begin{array}{l}10 \\
1_{0} \\
-- \\
-- \\
0\end{array}$ & $\begin{array}{l}<0.005 \\
-- \\
<.009 \\
<.002 \\
--\end{array}$ & $\begin{array}{l}<0.005 \\
-- \\
<.009 \\
<.002 \\
--\end{array}$ & $\begin{array}{l}<10 \\
-- \\
<1 \\
<0.13 \\
--\end{array}$ \\
\hline \multicolumn{5}{|c|}{ Collector well 41 (fig. 1) } \\
\hline $\begin{array}{r}11 / 19 / 2003 \\
12 / 17 / 2003 \\
1 / 28 / 2004 \\
2 / 25 / 2004 \\
3 / 30 / 2004 \\
5 / 4 / 2004 \\
5 / 26 / 2004 \\
7 / 13 / 2004 \\
9 / 8 / 2004\end{array}$ & $\begin{array}{l}10 \\
10 \\
0 \\
-- \\
-- \\
-- \\
-- \\
-- \\
0\end{array}$ & $\begin{aligned}<0.004 \\
<.048 \\
<.003 \\
<.002 \\
<.004 \\
<.011 \\
<.002 \\
<.002 \\
<.002\end{aligned}$ & $\begin{array}{l}<0.004 \\
<.048 \\
<.003 \\
<.002 \\
<.004 \\
<.011 \\
<.002 \\
<.002 \\
<.002\end{array}$ & $\begin{array}{l}<10 \\
<10 \\
<10 \\
<10 \\
<1.61 \\
<1 \\
<1 \\
<.11 \\
<.1\end{array}$ \\
\hline
\end{tabular}

${ }^{1}$ Independence Water Department (written commun., 2004).
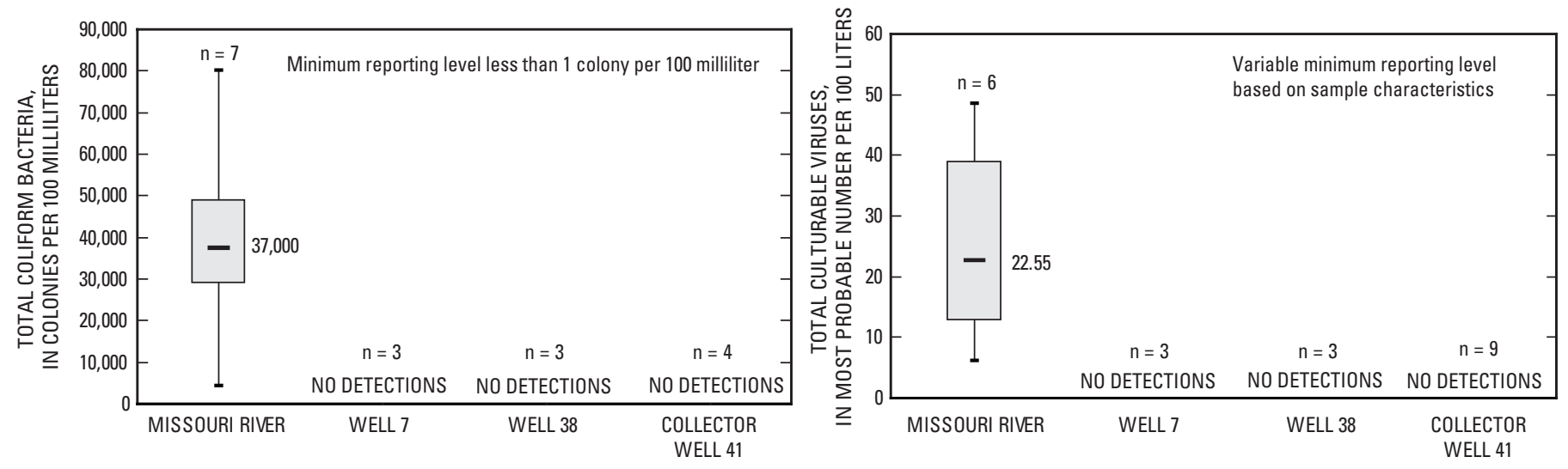

EXPLANATION

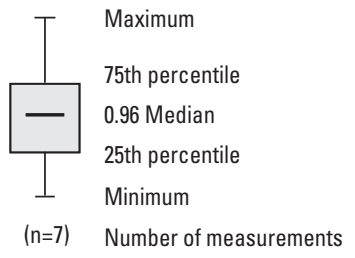

Figure 11. Statistical summary of total coliform bacteria and total culturable virusesin water samples from the Missouri River, wells 7 and 38 , and collector well 41 of the Independence well field. 

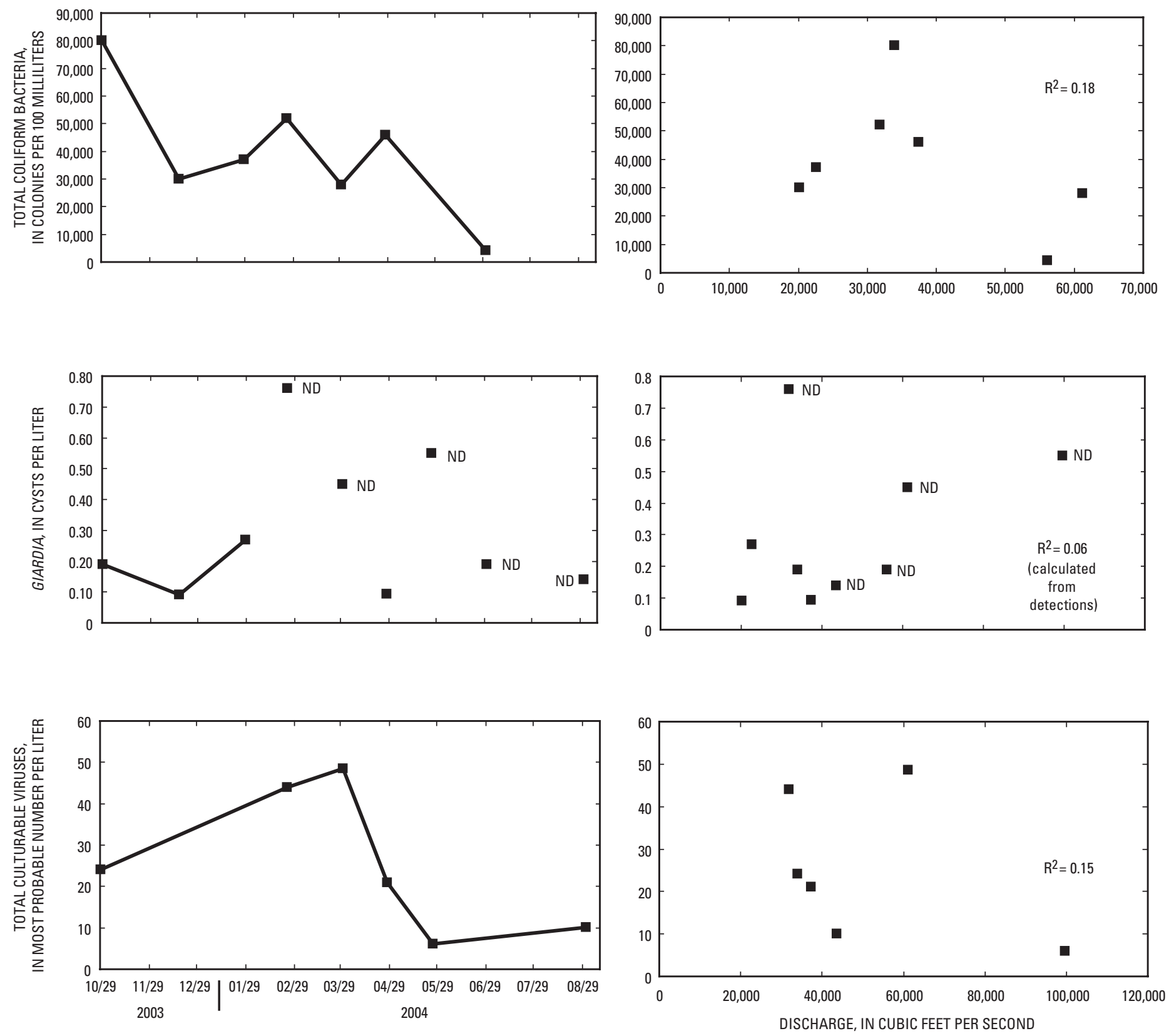

EXPLANATION

ND NONDETECT (VARIABLE DETECTION LIMIT PLOTTED)

NOTE: Trend lines not plotted for

correlation coefficient $\left(R^{2}\right)$ less than 0.5

Figure 12. Total coliform bacteria, Giardia, and total culturable viruses in water samples from the Missouri River with time and discharge. 
tion potentials analyzed in water samples during this study include dibromoacetic acid, dichloroacetic acid, monobromoacetic acid, monochloroacetic acid, and trichloroacetic acid. Results of six analyses for haloacetic acid formation potentials are listed in table 8 and summarized in figure 13.

In water samples from the Missouri River, the dichloroacetic acid and trichloroacetic acid formation potentials are the largest components of total haloacetic acid formation potential; in water samples from the wells, dibromoacetic acid and dichloroacetic acid formation potentials are the largest components of total haloacetic acid formation. Median values of dibromoacetic acid formation potential are smaller for samples from the Missouri River than for samples from wells, but median values for dichloroacetic acid, trichloroacetic acid, and total haloacetic acid formation potentials are substantially larger for samples from the Missouri River than for samples from the wells. Median values for monobromoacetic acid and monochloroacetic acid formation potentials are slightly larger for samples from the Missouri River than for samples from the wells. Median values for each haloacetic acid formation potential are similar among wells. Total haloacetic acid formation potentials were substantially smaller in the wells than in the Missouri River.
Changes in haloacetic acid formation potential in water samples from the Missouri River, wells 7 and 38, and collector well 41 with time, and in water samples from the Missouri River with discharge are shown in figure 14. In water samples from the Missouri River, the largest formation potentials for dibromoacetic acid and monobromoacetic acid occurred when formation potentials for dichloroacetic acid, monochloroacetic acid, trichloroacetic acid, and total haloacetic acid were smallest. The largest formation potentials for dichloroacetic acid, monochloroacetic acid, trichloroacetic acid, and total haloacetic acid occurred when formation potentials for dibromoacetic acid and monobromoacetic acid were smallest. Formation potentials for dichloroacetic acid, trichloroacetic acid, and total haloacetic acid in water samples from the Missouri River was related positively to discharge $\left(\mathrm{R}^{2}=0.72\right)$. Formation potentials for dibromoacetic acid, dichloroacetic acid, trichloroacetic acid, and total haloacetic acid remained fairly constant in water samples from wells. Changes in formation potential values for monobromoacetic acid and monochloroacetic acid in water samples from wells were similar to changes in values in water samples from the Missouri River.

Table 8. Haloacetic acid formation potentials in water samples from the Missouri River, wells 7 and 38, and collector well 41.

$[\mu \mathrm{g} / \mathrm{L}$, micrograms per liter; $<$, less than]

\begin{tabular}{|c|c|c|c|c|c|c|}
\hline \multirow[b]{2}{*}{$\begin{array}{l}\text { Sample } \\
\text { date }\end{array}$} & \multicolumn{6}{|c|}{${ }^{1}$ Formation potentials, in $\mu \mathrm{g} / \mathrm{L}$} \\
\hline & $\begin{array}{c}\text { Dibromoacetic } \\
\text { acid }\end{array}$ & $\begin{array}{c}\text { Dichloroacetic } \\
\text { acid }\end{array}$ & $\begin{array}{c}\text { Monobromoacetic } \\
\text { acid }\end{array}$ & $\begin{array}{c}\text { Monochloroacetic } \\
\text { acid }\end{array}$ & $\begin{array}{c}\text { Trichloroacetic } \\
\text { acid }\end{array}$ & $\begin{array}{c}\text { Total } \\
\text { haloacetic } \\
\text { acids }\end{array}$ \\
\hline \multicolumn{7}{|c|}{ Missouri River, middle (fig. 1) } \\
\hline $\begin{array}{r}10 / 29 / 2003 \\
12 / 17 / 2003 \\
1 / 28 / 2004 \\
2 / 24 / 2004 \\
3 / 30 / 2004 \\
4 / 27 / 2004\end{array}$ & $\begin{array}{l}3.9 \\
17 \\
26 \\
1.5 \\
5.0 \\
5.9\end{array}$ & $\begin{array}{r}130 \\
41 \\
31 \\
420 \\
620 \\
140\end{array}$ & $\begin{array}{l}2.2 \\
3.7 \\
5.1 \\
1.2 \\
3.4 \\
2.8\end{array}$ & $\begin{array}{c}8.2 \\
6.2 \\
9.3 \\
23 \\
24 \\
9.8\end{array}$ & $\begin{array}{r}150 \\
38 \\
17 \\
620 \\
970 \\
170\end{array}$ & $\begin{array}{c}294 \\
106 \\
88.4 \\
1,066 \\
1,622 \\
329\end{array}$ \\
\hline \multicolumn{7}{|c|}{ Well 7 (fig. 1) } \\
\hline $\begin{array}{r}11 / 19 / 2003 \\
12 / 17 / 2003 \\
1 / 28 / 2004 \\
2 / 25 / 2004 \\
3 / 31 / 2004 \\
5 / 26 / 2004\end{array}$ & $\begin{array}{l}12 \\
12 \\
16 \\
19 \\
20 \\
21\end{array}$ & $\begin{array}{c}19 \\
14 \\
9.8 \\
9.2 \\
6.7 \\
7.4\end{array}$ & $\begin{array}{l}1.7 \\
1.8 \\
2.4 \\
1.1 \\
2.4 \\
2.7\end{array}$ & $\begin{array}{l}6.5 \\
5.2 \\
6.9 \\
12 \\
<2.0 \\
<2.0\end{array}$ & $\begin{array}{c}16 \\
11 \\
4.4 \\
3.3 \\
2.1 \\
2\end{array}$ & $\begin{array}{l}55.2 \\
44.0 \\
39.5 \\
44.6 \\
31.2 \\
33.1\end{array}$ \\
\hline \multicolumn{7}{|c|}{ Well 38 (fig. 1) } \\
\hline $\begin{array}{r}11 / 5 / 2003 \\
12 / 17 / 2003 \\
1 / 28 / 2004 \\
2 / 25 / 2004 \\
3 / 31 / 2004 \\
5 / 4 / 2004\end{array}$ & $\begin{array}{l}12 \\
14 \\
13 \\
15 \\
15 \\
22\end{array}$ & $\begin{array}{l}21 \\
15 \\
18 \\
19 \\
22 \\
12\end{array}$ & $\begin{array}{r}1.4 \\
2 \\
2.2 \\
<1.0 \\
1.9 \\
2.8\end{array}$ & $\begin{array}{c}9.6 \\
5.5 \\
8.2 \\
11 \\
<2.0 \\
<2.0\end{array}$ & $\begin{array}{c}12 \\
9.9 \\
11 \\
10 \\
13 \\
4.6\end{array}$ & $\begin{array}{l}56.0 \\
46.4 \\
52.4 \\
55.0 \\
51.9 \\
41.4\end{array}$ \\
\hline \multicolumn{7}{|c|}{ Collector well 41 (fig. 1) } \\
\hline $\begin{array}{r}11 / 19 / 2003 \\
12 / 17 / 2003 \\
1 / 28 / 2004 \\
2 / 25 / 2004 \\
3 / 30 / 2004 \\
5 / 4 / 2004\end{array}$ & $\begin{array}{l}14 \\
16 \\
18 \\
20 \\
22 \\
16\end{array}$ & $\begin{array}{l}12 \\
9 \\
8 \\
8.1 \\
12 \\
15\end{array}$ & $\begin{array}{l}1.9 \\
2.4 \\
1.9 \\
1.1 \\
2.9 \\
2.1\end{array}$ & $\begin{array}{c}5.5 \\
4.8 \\
4 \\
12 \\
<2.0 \\
2.1\end{array}$ & $\begin{array}{l}7.3 \\
4.2 \\
2.6 \\
2.8 \\
5.3 \\
9.1\end{array}$ & $\begin{array}{l}40.7 \\
36.4 \\
34.5 \\
44.0 \\
42.2 \\
44.3\end{array}$ \\
\hline
\end{tabular}

${ }^{1}$ Samples analyzed for haloacetic acid formation potentials are dosed with chlorine, adjusted to a neutral $\mathrm{pH}$, incubated for 7 days at 25 degrees Celsius, and analyzed for haloacetic acids at the end of the incubation period. 
24 Water-Quality Changes Caused by Riverbank Filtration Between the Missouri River and Three Pumping Wells
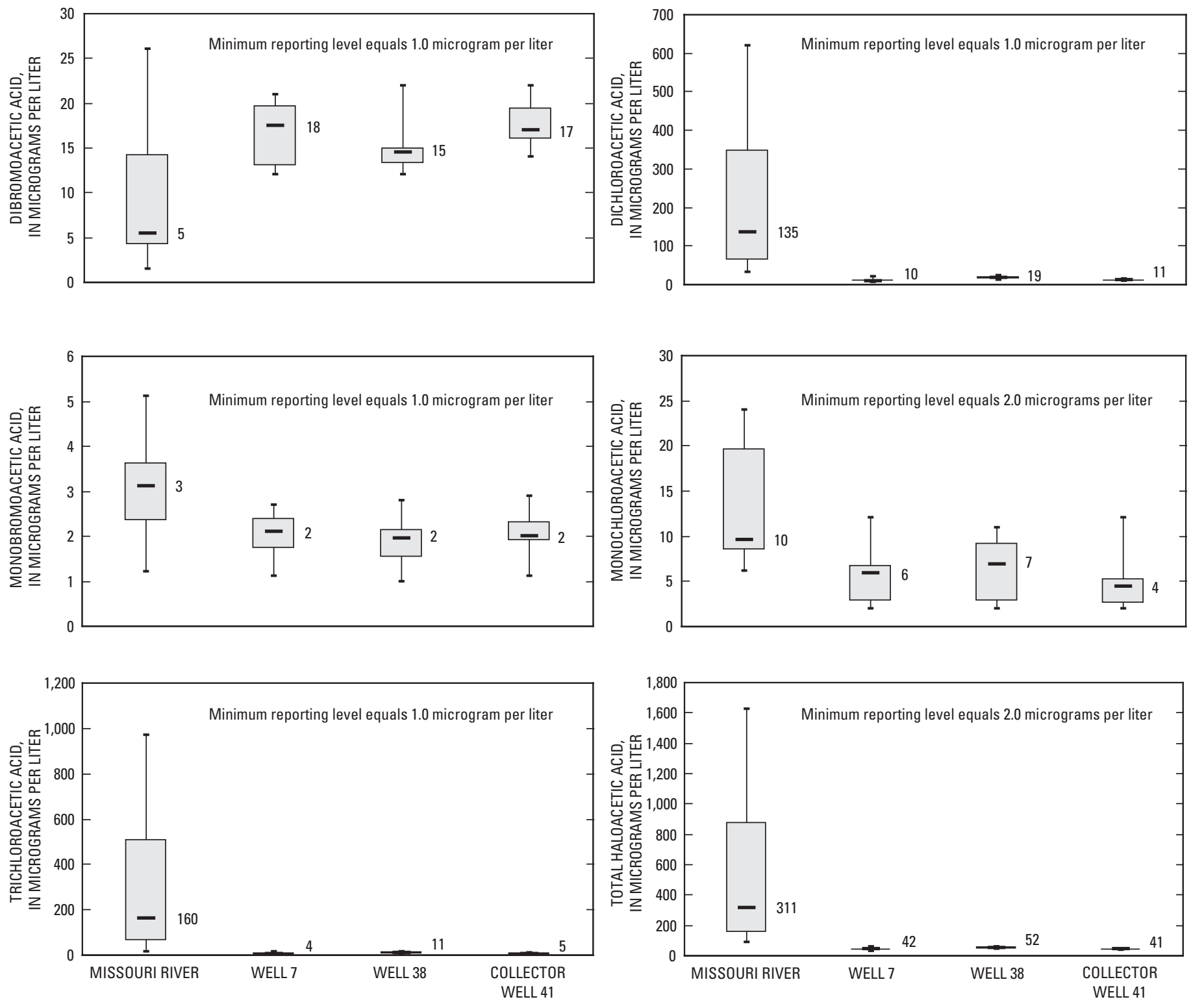

EXPLANATION

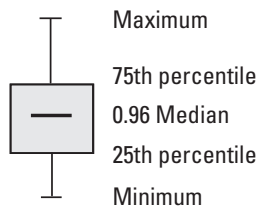

Figure 13. Statistical summary of haloacetic acid formation potentials in six water samples from the Missouri River, wells 7 and 38 , and collector well 41 of the Independence well field. 

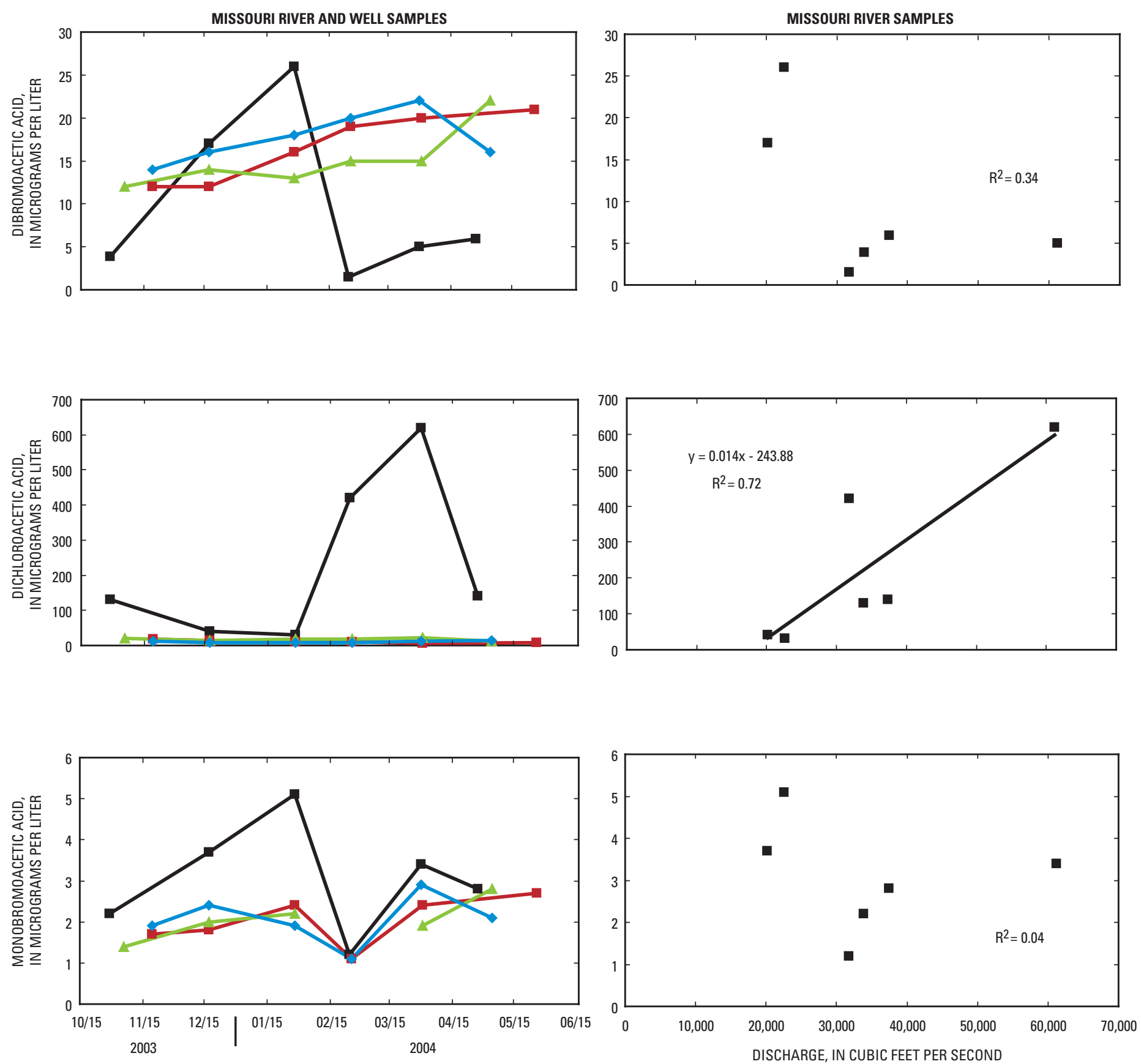

EXPLANATION
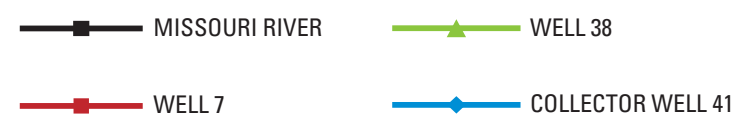

NOTE: Trend lines not plotted for

correlation coefficient $\left(\mathrm{R}^{2}\right)$ less than 0.5

Figure 14. Haloacetic acid formation potential concentrations in water samples from the Missouri River, wells 7 and 38 , and collector well 41 with time, and in water samples from the Missouri River with discharge. 

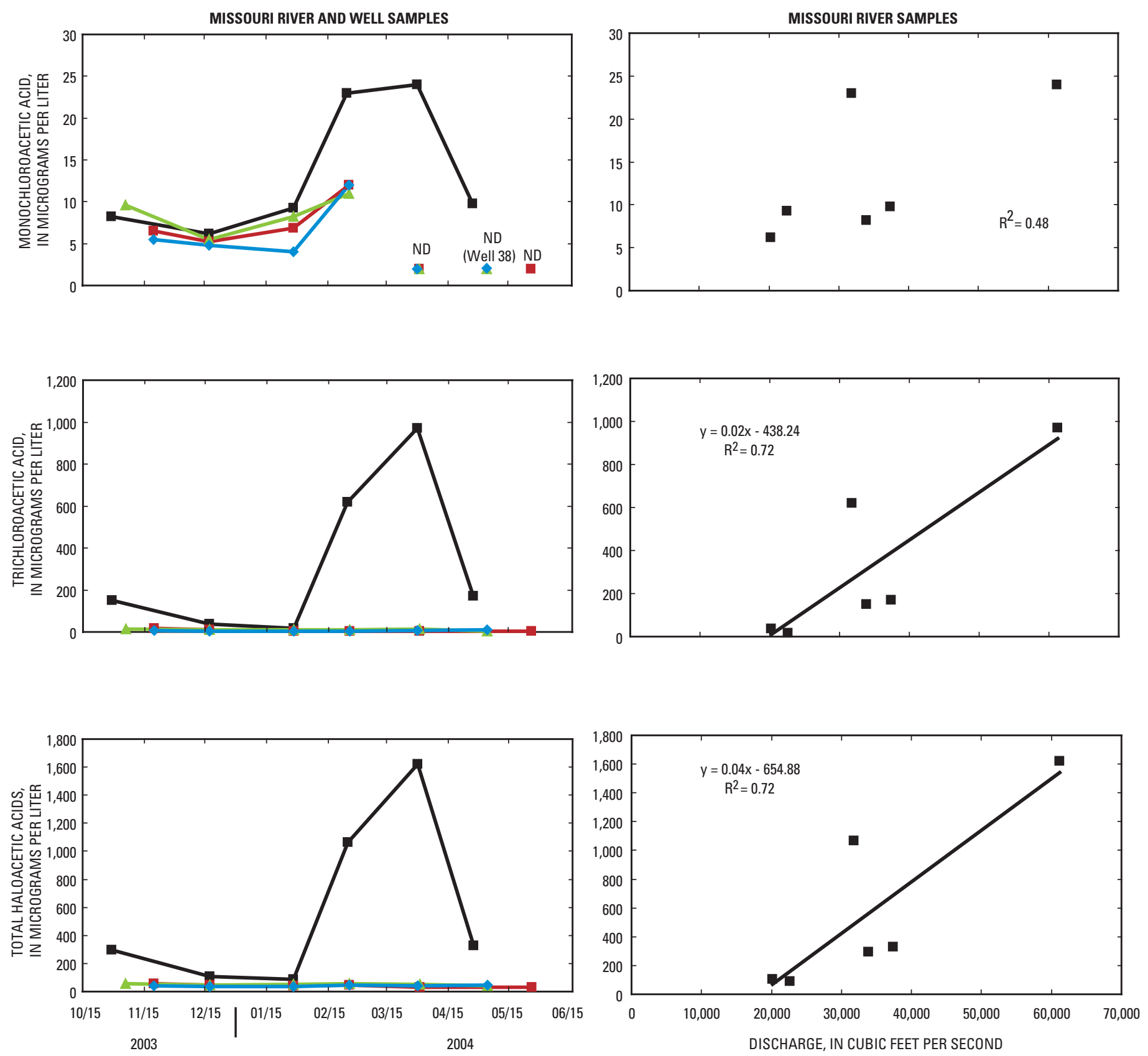

Figure 14. Haloacetic acid formation potential concentrations in water samples from the Missouri River, wells 7 and 38, and collector well 41 with time, and in water samples from the Missouri River with discharge-Continued.

Trihalomethane formation potentials measured in water samples during this study include bromodichloromethane, bromoform, chloroform, and dibromochloromethane. Results of analyses for trihalomethane formation potentials are listed in table 9 and summarized in figure 15.

Bromodichloromethane and chloroform formation potentials are the largest components of total trihalomethane formation potential in water samples from the Missouri River, whereas bromodichloromethane and dibromochloromethane formation potentials are the largest components in water sam- ples from the wells. The median value for bromodichloromethane formation potential was larger for samples from the Missouri River than for samples from the wells. Median values of bromoform and dibromochloromethane formation potentials are smaller for samples from the Missouri River than for samples from wells, but median values for chloroform and total trihalomethane formation potentials are substantially larger for samples from the Missouri River than for samples from the wells. Median values for each trihalomethane formation potential have only minor variations among wells. 
Table 9. Trihalomethane formation potentials in water samples from the Missouri River, wells 7 and 38, and collector well 41.

$[\mu \mathrm{g} / \mathrm{L}$, micrograms per liter; $<$, less than]

\begin{tabular}{|c|c|c|c|c|c|}
\hline \multirow[b]{2}{*}{$\begin{array}{c}\text { Sample } \\
\text { date }\end{array}$} & \multicolumn{5}{|c|}{${ }^{1}$ Formation potentials, in $\mu \mathrm{g} / \mathrm{L}$} \\
\hline & Bromodichloromethane & Bromoform & Chloroform & Dibromochloromethane & $\begin{array}{c}\text { Total } \\
\text { trihalomethanes }\end{array}$ \\
\hline \multicolumn{6}{|c|}{ Missouri River, middle (fig. 1) } \\
\hline $10 / 29 / 2003$ & 58 & 0.9 & 190 & 15 & 264 \\
\hline $12 / 17 / 2003$ & 100 & 14 & 85 & 73 & 272 \\
\hline $1 / 28 / 2004$ & 130 & 62 & 49 & 160 & 401 \\
\hline $2 / 24 / 2004$ & 58 & $<.5$ & 530 & 6.1 & 594 \\
\hline $3 / 30 / 2004$ & 120 & .9 & 620 & 22 & 763 \\
\hline $4 / 27 / 2004$ & 50 & 1.7 & 120 & 20 & 192 \\
\hline \multicolumn{6}{|c|}{ Well 7 (fig. 1) } \\
\hline $11 / 19 / 2003$ & 50 & 8.2 & 39 & 45 & 142 \\
\hline $12 / 17 / 2003$ & 53 & 13 & 28 & 48 & 142 \\
\hline $1 / 28 / 2004$ & 51 & 34 & 16 & 71 & 172 \\
\hline $2 / 25 / 2004$ & 40 & 38 & 12 & 70 & 160 \\
\hline $3 / 31 / 2004$ & 29 & 50 & 6.8 & 67 & 153 \\
\hline $5 / 26 / 2004$ & 34 & 47 & 7.6 & 73 & 162 \\
\hline \multicolumn{6}{|c|}{ Well 38 (fig. 1) } \\
\hline $11 / 5 / 2003$ & 69 & 18 & 44 & 65 & 196 \\
\hline $12 / 17 / 2003$ & 57 & 17 & 28 & 57 & 159 \\
\hline $1 / 28 / 2004$ & 66 & 18 & 37 & 59 & 180 \\
\hline $2 / 25 / 2004$ & 61 & 19 & 36 & 65 & 181 \\
\hline $3 / 31 / 2004$ & 55 & 15 & 34 & 58 & 162 \\
\hline $5 / 4 / 2004$ & 46 & 43 & 14 & 85 & 188 \\
\hline \multicolumn{6}{|c|}{ Collector well 41 (fig. 1) } \\
\hline $11 / 19 / 2003$ & 45 & 16 & 23 & 61 & 145 \\
\hline $12 / 17 / 2003$ & 41 & 29 & 13 & 61 & 144 \\
\hline $1 / 28 / 2004$ & 45 & 50 & 11 & 80 & 186 \\
\hline $2 / 25 / 2004$ & 40 & 50 & 9.9 & 85 & 185 \\
\hline $3 / 30 / 2004$ & 54 & 38 & 18 & 86 & 196 \\
\hline $5 / 4 / 2004$ & 53 & 17 & 26 & 59 & 155 \\
\hline
\end{tabular}

${ }^{1}$ Samples analyzed for trihalomethane formation potentials are dosed with chlorine, adjusted to a neutral $\mathrm{pH}$, incubated for 7 days at 25 degrees Celsius, and analyzed for trihalomethanes at the end of the incubation period.

Changes in trihalomethane formation potential in water samples from the Missouri River, wells 7 and 38, and collector well 41 with time, and in water samples from the Missouri River with discharge are shown in figure 16. Chloroform formation potential in water samples from the Missouri River was related positively to discharge $\left(\mathrm{R}^{2}=0.56\right)$. Formation potentials for bromodichloromethane, chloroform, dibromochloromethane, and total trihalomethanes are more variable in water samples from the Missouri River than in water samples from wells, but the variability of formation potentials for bromoform was similar between water samples from the Missouri River and wells.

\section{Water-Quality Changes Caused by Riverbank Filtration Between the Missouri River and Three Pumping Wells}

The change in source-water quality caused by riverbank filtration to the Independence well field was determined by comparing the values of physical properties, organic material, organic indicators, nutrients, total coliform bacteria, Cryptosporidium, Giardia, total culturable viruses, and disin- fection by-product formation potentials in water samples from the Missouri River to the values in water samples from wells 7 and 38 and collector well 41 . The median value and the change in median values between Missouri River water samples, water samples from wells 7 and 38, and collector well 41 are listed in table 10. The conservative assumption of using the minimum reporting level for analytical results below detection rather than zero was used to calculate the change in median concentration between river samples and well samples if results of analyses were below the detection limit. For Cryptosporidium and Giardia, detections in water samples from the Missouri River were too few to calculate a representative median value, but nondetect values in water samples from wells were smaller and more uniform. Analytical results in water samples from the Missouri River and water samples from all wells were compared to determine if differences in median values between Missouri River samples and well samples were greater than would be expected by chance. The Mann-Whitney rank-sum test results indicate the medians were statistically different for all constituents except for specific conductance, temperature, SUVA, and dissolved ammonia.

Median values of total coliform bacteria, Cryptosporidium, Giardia, and total culturable viruses decreased substantially between the Missouri River and wells. Concentrations of 


\section{Water-Quality Changes Caused by Riverbank Filtration Between the Missouri River and Three Pumping Wells}

bacteria, protozoa, and viruses were below the detection limit in all water samples from the wells; however, if the amount of change between water samples from the Missouri River and water samples from the wells was calculated using the minimum reporting level for each analysis below detection, total coliform bacteria decreased 100 percent, Cryptosporidium decreased between 96 and 98 percent, Giardia decrease between 97 and 98 percent, and total culturable viruses decreased between 85 and 96 percent. The percent reduction of total coliform bacteria, Cryptosporidium, Giardia, and total culturable viruses between water samples from the Missouri River
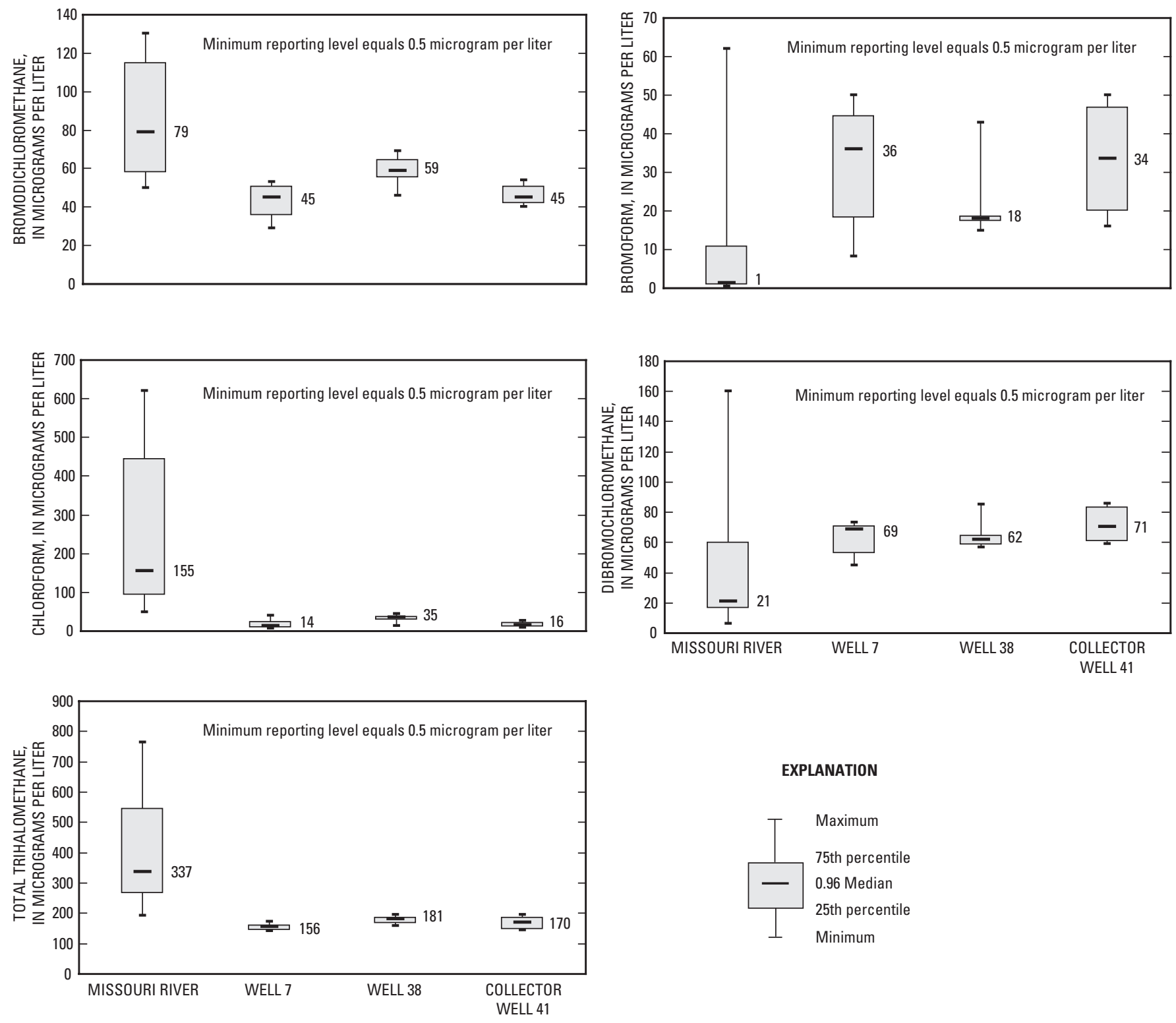

and all three wells would be 100 percent if non-detections were set equal to zero.

Decreases in turbidity, total coliform bacteria, Cryptosporidium, Giardia, and total culturable viruses from source water through a water-treatment process commonly are expressed in terms of log removal. The log removal for turbidity was 1.60 . Turbidity levels are associated with the presence of particulates and colloids in water, and when these are present, microorganisms such as bacteria, protozoa, and viruses also may be present; however, turbidity in well water may be caused by precipitation of dissolved iron in the sample or other processes in
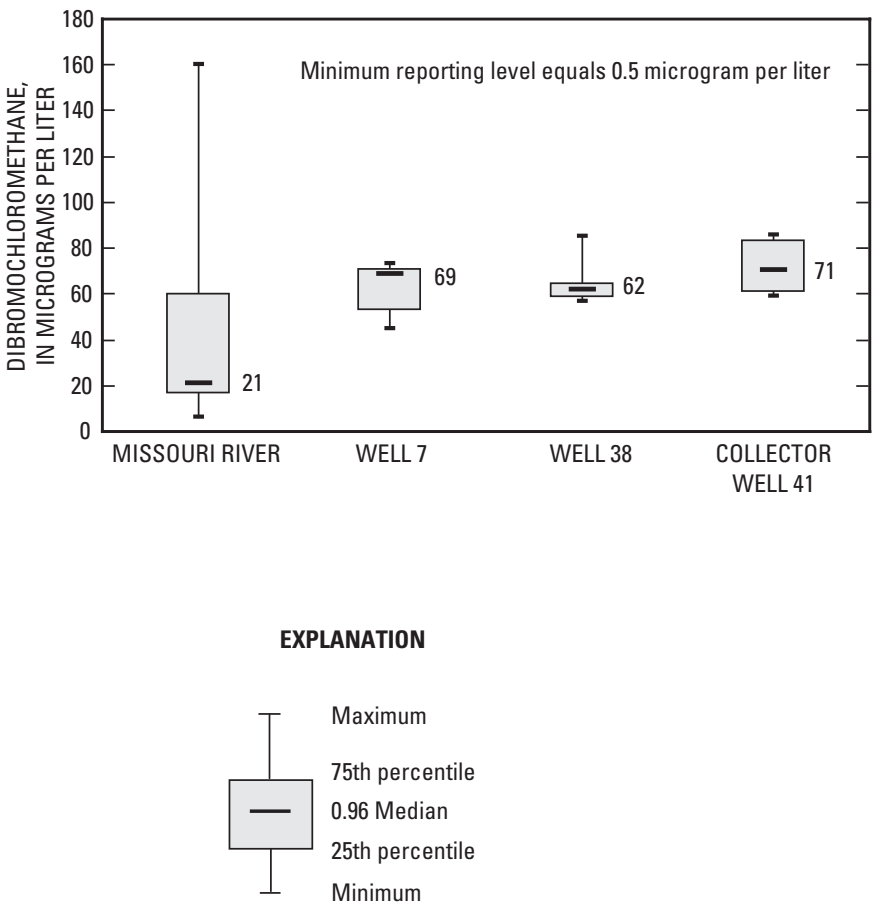

Figure 15. Statistical summary of trihalomethane formation potential concentrations in six water samples from the Missouri River, wells 7 and 38, and collector well 41 of the Independence well field. 

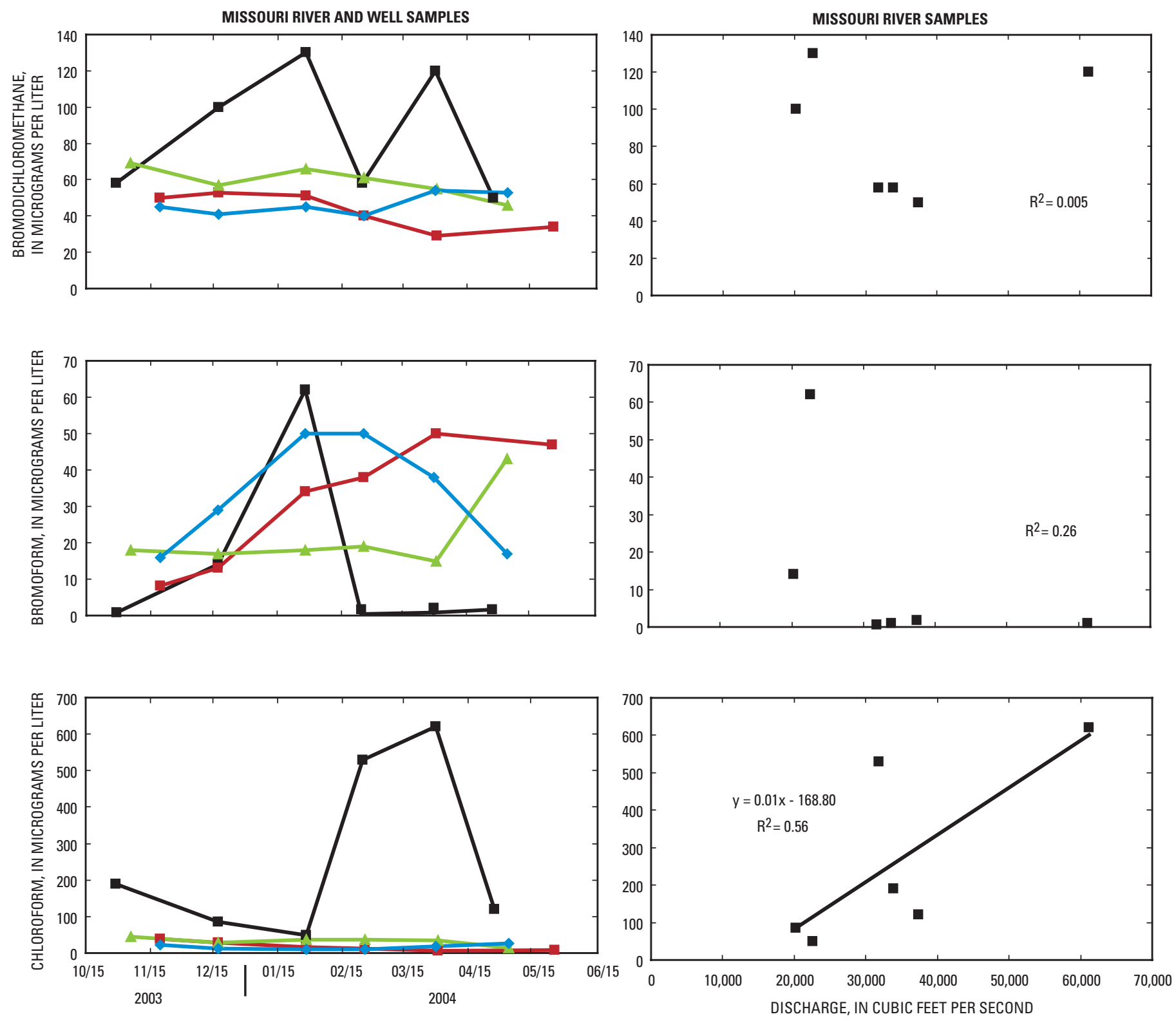

EXPLANATION

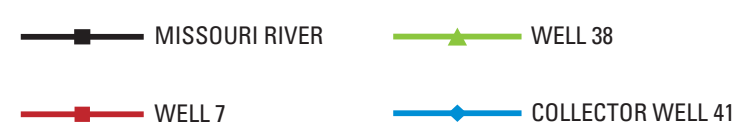

NOTE: Trend lines not plotted for

correlation coefficient $\left(R^{2}\right)$ less than 0.5

Figure 16. Trihalomethane formation potential concentrations in water samples from the Missouri River, wells 7 and 38 , and collector well 41 with time, and in water samples from the Missouri River with discharge. 

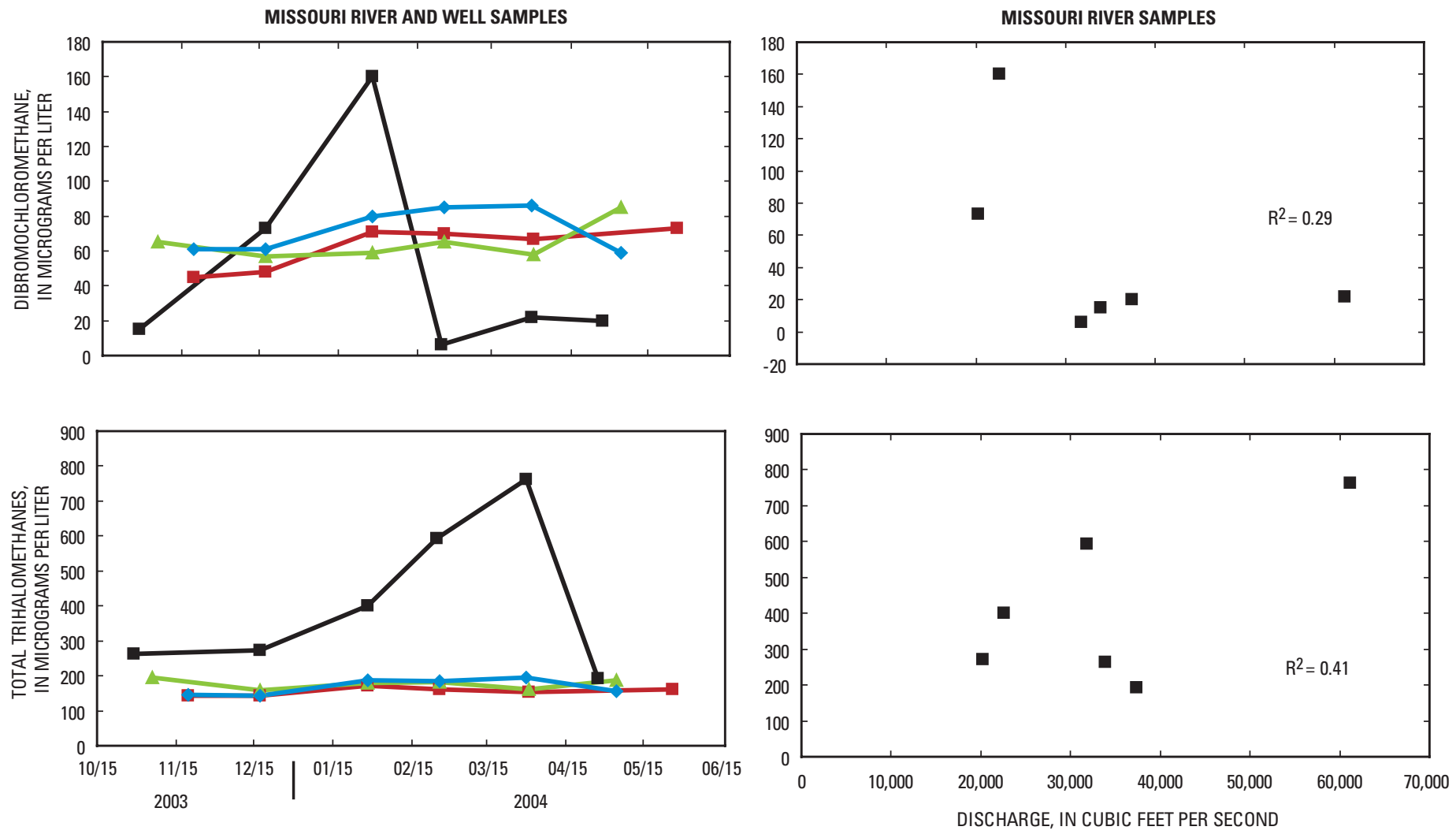

Figure 16. Trihalomethane formation potential concentrations in water samples from the Missouri River, wells 7 and 38 , and collector well 41 with time, and in water samples from the Missouri River with discharge-Continued.

the well. If this occurs, the actual log removal of particulates and colloids by riverbank filtration may be larger than indicated because the turbidity measured in water samples from the wells is not related to turbidity in the Missouri River. Log removals were calculated for total coliform bacteria, Cryptosporidium, Giardia, and total culturable viruses. Median values were calculated from detections in Missouri River samples for total coliform bacteria, Giardia, and total culturable viruses, but the value was used instead of a median value for the one detection of Cryptosporidium in the Missouri River water samples.

Median values for well samples were calculated using the minimum reporting level because all analytical results were below detection. The log removal for total coliform bacteria was greater than 4.57. This value was determined from five water samples from the Missouri River and four water samples from the wells. Large concentrations of total coliform bacteria were detected in all Missouri River samples, but not detected in any water samples from the wells; the minimum reporting level used for the calculations was $1 \mathrm{col} / 100 \mathrm{~mL}$. Log removal was greater than 1.67 for Cryptosporidium, and was greater than 1.67 for Giardia. Neither was detected in samples from the wells. Cryptosporidium was detected in one of nine samples, and Giardia was detected in four of nine samples from the Missouri River. Total culturable viruses were not detected in any samples from the wells but were detected in all six samples from the
Missouri River. Log removal for total culturable virus was greater than 1.15. Because no total coliform bacteria, Cryptosporidium, Giardia, or total culturable viruses were detected in water samples from the wells, a conservative estimate of $\log$ removals between the Missouri River and wells was made by using the minimum reporting level for non detects rather than zero. Actual log removals of these organisms were greater. The effect on calculated log removals using one-half and one-tenth of the minimum reporting level was to increase the reported log removals for each microbial pathogen (fig. 17).

\section{Water-Quality Changes Between the Missouri River and Three Pumping Wells Based on Estimated Ground-Water Traveltimes}

A comparison of river-water temperature changes with ground-water temperature changes (fig. 6) provides an estimate of the traveltime of water from the river to the pumping wells. Other studies have used temperature changes to characterize the interaction between surface water and ground water, and to estimate traveltime with some success (Hunt and others, 2005, Stonestrom and Constanz, 2003). More accurate estimates of 
Table 10. Median values and change in median values in water quality of water samples between the Missouri River, wells 7 and 38 , collector well 41 , and all wells.

[MRL, minimum reporting level; mg/L, milligrams per liter; $\mu \mathrm{S} / \mathrm{cm}$, microsiemens per centimeter; ${ }^{\circ} \mathrm{C}$, degrees Celsius; NTU, nephelometric turbidity units; UV254, ultraviolet absorbance at 254 nanometers; $\mathrm{u} / \mathrm{cm}$, units per centimeter; --, no data; SUVA, specific ultraviolet absorbance at 254 nanometers; $\mu \mathrm{g} / \mathrm{L}$, micrograms per liter; N, nitrogen; <, less than; P, phosphorous; col/100 mL,

colonies per 100 milliliters; oocysts/L, oocysts per liter; cysts/L, cysts per liter; MPN/L, most probable number per liter]

\begin{tabular}{|c|c|c|c|c|c|c|c|c|c|c|c|}
\hline & \multirow[b]{2}{*}{ Units } & \multirow[b]{2}{*}{ MRL } & \multicolumn{5}{|c|}{ Median value } & \multicolumn{4}{|c|}{$\begin{array}{c}\text { Percent change in median value between } \\
\text { Missouri River and well }\end{array}$} \\
\hline & & & Missouri River & Well 7 & Well 38 & Collector Well 41 & All Wells & Well 7 & Well 38 & Well 41 & All Wells \\
\hline \multicolumn{12}{|c|}{ Dissolved oxygen and physical properties } \\
\hline $\begin{array}{l}\text { Dissolved oxygen } \\
\text { pH } \\
\text { Specific conductance } \\
\text { Temperature } \\
\text { Turbidity }\end{array}$ & $\begin{array}{c}\mathrm{mg} / \mathrm{L} \\
\mu \mathrm{S} / \mathrm{cm} \\
{ }^{\circ} \mathrm{C} \\
\text { NTU }\end{array}$ & $\begin{array}{r}0.1 \\
.1 \\
.1 \\
.1 \\
\mathrm{na}\end{array}$ & $\begin{array}{r}9.5 \\
8.2 \\
682 \\
15.0 \\
130\end{array}$ & $\begin{array}{c}1.4 \\
7.4 \\
727 \\
13.9 \\
5.0\end{array}$ & $\begin{array}{r}0.1 \\
7.5 \\
713 \\
14.7 \\
9.6\end{array}$ & $\begin{array}{c}0.3 \\
7.5 \\
711 \\
14.6 \\
2.0\end{array}$ & $\begin{array}{c}0.3 \\
7.5 \\
713 \\
14.5 \\
3.3\end{array}$ & $\begin{array}{r}-86 \\
-10 \\
7 \\
-7 \\
-96\end{array}$ & $\begin{array}{r}-99 \\
-9 \\
5 \\
-2 \\
-93\end{array}$ & $\begin{array}{r}-97 \\
-9 \\
4 \\
-3 \\
-98\end{array}$ & $\begin{array}{r}-97 \\
-9 \\
5 \\
-3 \\
-97\end{array}$ \\
\hline \multicolumn{12}{|c|}{ Organic material and organic indicators } \\
\hline $\begin{array}{l}\text { Dissolved organic carbon } \\
\text { UV254 } \\
\text { SUVA } \\
\text { Chlorophyll } a \\
\text { Tannin and lignin }\end{array}$ & $\begin{array}{l}\mathrm{mg} / \mathrm{L} \\
\mathrm{u} / \mathrm{cm} \\
\mu \mathrm{g} / \mathrm{L} \\
\mathrm{mg} / \mathrm{L}\end{array}$ & $\begin{array}{l}0.33 \\
.0035 \\
-- \\
.1 \\
.1\end{array}$ & $\begin{array}{l}3.6 \\
0.09 \\
2.29 \\
11.0 \\
2.3\end{array}$ & $\begin{array}{l}2.3 \\
0.05 \\
2.42 \\
<.1 \\
1.5\end{array}$ & $\begin{array}{l}2.5 \\
.06 \\
2.48 \\
<.1 \\
2.1\end{array}$ & $\begin{array}{l}2.3 \\
.06 \\
2.70 \\
<.1 \\
1.2\end{array}$ & $\begin{array}{l}2.4 \\
0.06 \\
2.50 \\
<.1 \\
1.5\end{array}$ & $\begin{array}{r}-36 \\
-40 \\
6 \\
-99 \\
-35\end{array}$ & $\begin{array}{r}-31 \\
-31 \\
8 \\
-99 \\
-11\end{array}$ & $\begin{array}{r}-36 \\
-31 \\
18 \\
-99 \\
-50\end{array}$ & $\begin{array}{r}-33 \\
-33 \\
9 \\
-99 \\
-35\end{array}$ \\
\hline \multicolumn{12}{|c|}{ Nutrients, dissolved } \\
\hline $\begin{array}{l}\text { Dissolved ammonia as } \mathrm{N} \\
\text { Dissolved nitrite as } \mathrm{N} \\
\text { Dissolved nitrate as } \mathrm{N} \\
\text { Dissolved orthophosphorous as } \mathrm{P}\end{array}$ & $\begin{array}{l}\mathrm{mg} / \mathrm{L} \\
\mathrm{mg} / \mathrm{L} \\
\mathrm{mg} / \mathrm{L} \\
\mathrm{mg} / \mathrm{L}\end{array}$ & $\begin{array}{l}0.02 \\
.01 \\
.05 \\
.01\end{array}$ & $\begin{array}{r}0.08 \\
.02 \\
1.38 \\
.09\end{array}$ & $\begin{array}{l}0.06 \\
<.01 \\
<.01 \\
<.01\end{array}$ & $\begin{array}{l}0.20 \\
<.01 \\
<.01 \\
<.01\end{array}$ & $\begin{array}{r}0.08 \\
.02 \\
.68 \\
<.01\end{array}$ & $\begin{array}{r}0.08 \\
.01 \\
.05 \\
<.01\end{array}$ & $\begin{array}{l}-25 \\
-50 \\
-99 \\
-89\end{array}$ & $\begin{array}{l}150 \\
-50 \\
-99 \\
-89\end{array}$ & $\begin{array}{r}0 \\
-5 \\
-51 \\
-89\end{array}$ & $\begin{array}{r}0 \\
-50 \\
-96 \\
-89\end{array}$ \\
\hline \multicolumn{12}{|c|}{ Total coliform bacteria, Cryptosporidium, Giardia, and total culturable viruses } \\
\hline $\begin{array}{l}\text { Total coliform bacteria } \\
\text { Cryptosporidium } \\
\text { Giardia } \\
\text { Total culturable virus }\end{array}$ & $\begin{array}{l}\text { col/100 mL } \\
\text { oocysts/L } \\
\text { cysts/L } \\
\text { MPN/L }\end{array}$ & $\begin{array}{l}0 \\
-- \\
-- \\
--\end{array}$ & $\begin{array}{r}37,000 \\
.14 \\
.14 \\
22.55\end{array}$ & $\begin{array}{l}0 \\
<.003 \\
<.003 \\
<3.33\end{array}$ & $\begin{array}{l}0 \\
<.005 \\
<.005 \\
<1.00\end{array}$ & $\begin{array}{l}0 \\
<.003 \\
<.003 \\
<1.61\end{array}$ & $\begin{array}{l}0 \\
<.003 \\
<.003 \\
<1.61\end{array}$ & $\begin{array}{r}-100 \\
-98 \\
-98 \\
-85\end{array}$ & $\begin{array}{r}-100 \\
-96 \\
-96 \\
-96\end{array}$ & $\begin{array}{r}-100 \\
-98 \\
-98 \\
-93\end{array}$ & $\begin{array}{r}-100 \\
-98 \\
-98 \\
-93\end{array}$ \\
\hline \multicolumn{12}{|c|}{ Haloacetic acid formation potentials } \\
\hline $\begin{array}{l}\text { Dibromoacetic acid } \\
\text { Dichloroacetic acid } \\
\text { Monobromoacetic acid } \\
\text { Monochloroacetic acid } \\
\text { Trichloroacetic acid } \\
\text { Total Haloacetic acids }\end{array}$ & $\begin{array}{l}\mu g / L \\
\mu g / L \\
\mu g / L \\
\mu g / L \\
\mu g / L \\
\mu g / L\end{array}$ & $\begin{array}{l}1.0 \\
1.0 \\
1.0 \\
1.0 \\
1.0 \\
1.0\end{array}$ & $\begin{array}{r}5 \\
135 \\
3 \\
10 \\
160 \\
311\end{array}$ & $\begin{array}{r}18 \\
10 \\
2 \\
6 \\
4 \\
42\end{array}$ & $\begin{array}{r}15 \\
19 \\
2 \\
7 \\
11 \\
52\end{array}$ & $\begin{array}{r}17 \\
11 \\
2 \\
4 \\
5 \\
41\end{array}$ & $\begin{array}{r}16 \\
12 \\
2 \\
4 \\
6 \\
44\end{array}$ & $\begin{array}{l}221 \\
-93 \\
-32 \\
-39 \\
-98 \\
-87\end{array}$ & $\begin{array}{l}166 \\
-86 \\
-37 \\
-28 \\
-93 \\
-83\end{array}$ & $\begin{array}{l}212 \\
-92 \\
-35 \\
-54 \\
-97 \\
-87\end{array}$ & $\begin{array}{l}194 \\
-91 \\
-37 \\
-44 \\
-96 \\
-86\end{array}$ \\
\hline \multicolumn{12}{|c|}{ Trihalomethane formation potentials } \\
\hline $\begin{array}{l}\text { Bromodichloromethane } \\
\text { Bromoform } \\
\text { Chloroform } \\
\text { Dibromochloromethane } \\
\text { Total trihalomethanes }\end{array}$ & $\begin{array}{l}\mu g / L \\
\mu g / L \\
\mu g / L \\
\mu g / L \\
\mu g / L\end{array}$ & $\begin{array}{r}0.5 \\
.5 \\
.5 \\
.5 \\
.5\end{array}$ & $\begin{array}{r}79 \\
1 \\
155 \\
21 \\
337\end{array}$ & $\begin{array}{r}45 \\
36 \\
14 \\
69 \\
156\end{array}$ & $\begin{array}{r}59 \\
18 \\
35 \\
62 \\
181\end{array}$ & $\begin{array}{r}45 \\
34 \\
16 \\
71 \\
170\end{array}$ & $\begin{array}{r}51 \\
24 \\
21 \\
65 \\
162\end{array}$ & $\begin{array}{r}-43 \\
2,669 \\
-91 \\
226 \\
-54\end{array}$ & $\begin{array}{r}-25 \\
1,285 \\
-77 \\
195 \\
-46\end{array}$ & $\begin{array}{r}-43 \\
2,477 \\
-90 \\
236 \\
-49\end{array}$ & $\begin{array}{r}-36 \\
1,746 \\
-87 \\
210 \\
-52\end{array}$ \\
\hline
\end{tabular}




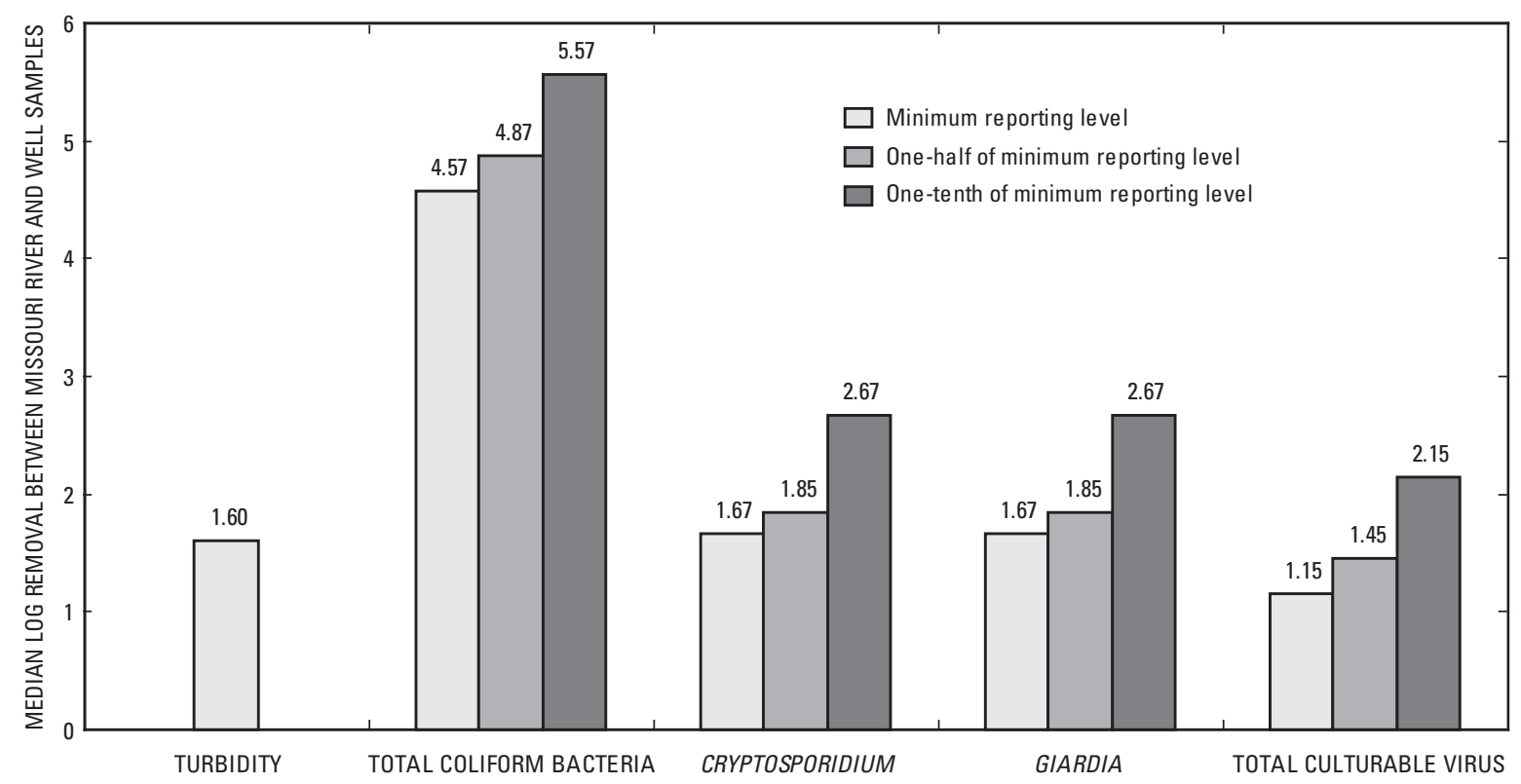

Figure 17. Median log removals of turbidity, total coliform bacteria, Cryptosporidium, Giardia, and total culturable viruses calculated using the minimum reporting level, one-half the minimum reporting level, and one-tenth the minimum reporting level between water samples from the Missouri River and water samples from wells.

traveltime using temperature are made when ground-water flow is relatively rapid and heat is transported by advective groundwater flow (and not conductance or convection), as is the case for ground-water flow rates in the Missouri River alluvial aquifer.

The lowest Missouri River water temperature $\left(0.5^{\circ} \mathrm{C}\right)$ was recorded on January 28, 2004. Lowest water temperature for well $7\left(7.8^{\circ} \mathrm{C}\right)$ was recorded on May 26, 2004, for well 38 (13.1 $\left.{ }^{\circ} \mathrm{C}\right)$ on September 8, 2004, and for collector well $41\left(8.6^{\circ} \mathrm{C}\right)$ on February 25, 2004. Approximate traveltimes from the river to the wells based on water temperature profiles were 4 months for well 7, 7 to 9 months for well 38 , and 1 month for collector well 41. More accurate estimates of ground-water traveltimes also could be made with more frequent temperature measurement in the river and wells. Temperature signatures in the Missouri River and collector well 41 have been previously documented
(Camp, Dresser, and McKee, Inc., 2000). Estimated traveltimes from the river to collector well 41 ranged from 15 to 30 days for temperature peaks, and from 30 to 60 days for temperature lows. The difference in traveltime was attributed to lower water viscosity at higher temperatures, and higher water viscosity at lower temperatures.

An estimate of average ground-water flow velocity between the Missouri River bed and the screened interval of each well was made using distances from the south bank and from the deep channel of the Missouri River to the midpoint of the screened interval and the estimated traveltimes determined from temperature profiles measured for this report. Well depths, screened intervals, and distances from the Missouri River south bank and deep channel to the midpoint of the screened interval (wells 7 and 38) or the top tier of lateral screens (collector well 41), are listed in table 11.

Table 11. Well depths, screened intervals, and distance from the Missouri River to screened intervals of wells 7 and 38 and collector well 41.

\begin{tabular}{|c|c|c|c|}
\hline & Well 7 & Well 38 & Collector well 41 \\
\hline $\begin{array}{l}\text { Well depth, in feet } \\
\text { Top of screened interval, }\end{array}$ & 90 & 84 & 123 \\
\hline $\begin{array}{l}\text { Top of screened interval, } \\
\text { altitude, in feet, NGVD88 }\end{array}$ & 610 & 666 & (top tier of lateral screens) \\
\hline Bottom of screened interval, & & & 611 \\
\hline $\begin{array}{l}\text { altitude, in feet, NGVD88 } \\
\text { Diagonal distance from the south bank of the Missouri River down to }\end{array}$ & 660 & 636 & (bottom tier of lateral screens) \\
\hline $\begin{array}{l}\text { midpoint of screened interval, in feet } \\
\text { Diagonal distance from the deep channel of the Missouri River down to }\end{array}$ & 144 & 496 & -- \\
\hline $\begin{array}{l}\text { midpoint of screened interval, in feet } \\
\text { Vertical distance from the south bank of the Missouri River to top tier of }\end{array}$ & 804 & 1,182 & -- \\
\hline $\begin{array}{l}\text { lateral screens, in feet } \\
\text { Vertical distance from the deep channel of the Missouri River to top tier of }\end{array}$ & -- & -- & 84 \\
\hline lateral screens, in feet & -- & -- & 71 \\
\hline
\end{tabular}


The average rate of ground-water flow from the south bank of the Missouri River to the screened interval of well 7 was 1.2 $\mathrm{ft} /$ day (feet per day) and from the deep channel of the Missouri River to the screened interval was $6.7 \mathrm{ft} /$ day. The rate of ground-water flow from the south bank of the Missouri River to the screened interval of well 38 was $1.8 \mathrm{ft} /$ day, and from the deep channel of the Missouri River to the screened interval was $4.3 \mathrm{ft} / \mathrm{day}$. The rate of ground-water flow from the south bank of the Missouri River to the screened interval of collector well 41 was $2.8 \mathrm{ft} / \mathrm{day}$, and from the deep channel of the Missouri River to the screened interval was $2.4 \mathrm{ft} /$ day. These rates are somewhat less than rates typical of slow sand filters (6.5 to 16.5 $\mathrm{ft} /$ day) (Wang and others, 2002). Slower flow rates result in greater filtration, and indicate riverbank filtration at this site may be comparable to, or more effective than, a slow sand filter.

Samples from the Missouri River were compared to samples collected from wells at times that approximated the traveltime from the Missouri River to each well. Water-quality changes between samples from the Missouri River and samples collected at times that approximated the traveltime from the Missouri River to wells 7 and 38 and collector well 41 are listed in table 12 . There is no clear relation between water-quality changes and traveltime from the Missouri River to wells 7 and 38 and collector well 41, although the temperature trend between the Missouri River and wells indicate the movement of water. The absence of any trends in water quality between the Missouri River and the pumping wells indicates the strong influence of riverbank filtration. The largest changes to water quality between the river and wells most likely occurred within the first several feet of the Missouri River bed (Wang and others, 2002). With continued movement into the aquifer, river water mixes with ground water and further changes water quality.

Log removals based on minimum reporting levels were calculated for turbidity, total coliform bacteria, Giardia, and total culturable viruses between samples from the Missouri River and samples collected at times that approximated the traveltime from the Missouri River to wells 7 and 38 and collector well 41 (table 12). Log removals for Cryptosporidium were not included because it was detected only once at the end of the sampling period, and no corresponding well samples were collected. Because the minimum reporting level was used rather than zero for non detections, the range of log removals calculated (fig. 18) are minimum log removals. Minimum log removals in water samples based on ground-water traveltime between the Missouri River and wells are infinite for total coliform bacteria, and range from 0.8 to 3.5 for turbidity, 1.5 to 2.1 for Giardia, and 0.4 to 2.6 for total culturable viruses.

\section{Disinfection By-Product Formation Potentials and Organic Material, Organic Indicators, and Turbidity}

Changes of haloacetic acid and trihalomethane formation potentials in water samples from the Missouri River and wells were compared to determine their relation to changes in organic

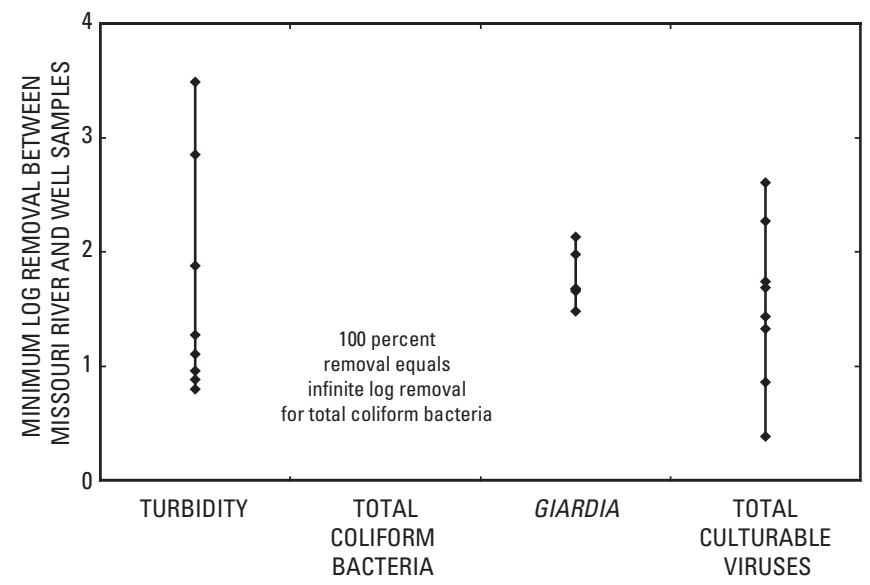

Figure 18. Minimum log removals of turbidity, total coliform bacteria, Giardia, and total culturable viruses in water samples from all wells based on ground-water traveltime between the Missouri River and wells.

material, organic indicators, and turbidity. Haloacetic acid formation potential in water samples from the Missouri River and all wells are plotted in relation to DOC, UV254, SUVA, tannin and lignin, and turbidity in figure 19 . Ultraviolet absorption at 254 nanometers $\left(\mathrm{R}^{2}=0.94\right)$, tannin and lignin $\left(\mathrm{R}^{2}=0.93\right)$, and turbidity $\left(\mathrm{R}^{2}=0.97\right)$ were the best predictors of haloacetic acid formation potential for water samples from the Missouri River. None of the variables were reliable predictors of haloacetic acid formation potential for water samples from all wells.

Trihalomethane formation potential in water samples from the Missouri River and all wells are plotted in relation to DOC, UV254, SUVA, tannin and lignin, and turbidity in figure 20. DOC $\left(\mathrm{R}^{2}=0.89\right), \mathrm{UV} 254\left(\mathrm{R}^{2}=0.85\right)$, tannin and lignin $\left(\mathrm{R}^{2}=\right.$ $0.90)$, and turbidity $\left(\mathrm{R}^{2}=0.89\right)$ were the best predictors of trihalomethane formation potential and SUVA was related positively, but less so $\left(\mathrm{R}^{2}=0.51\right)$. None of the variables were reliable predictors for trihalomethane formation potential in water samples from all wells.

\section{Cross-Sectional Distribution of Selected Compounds and Properties in the Missouri River}

Because most wells of the Independence well field are near the bank and a large part of total well field pumpage is induced from the Missouri River, contaminants in the river could result in a higher risk of contamination of the well field. The crosssectional distributions of specific conductance and organic wastewater compounds in the Missouri River near the Independence well field were determined to assess the influence of point sources of wastewater along the Missouri River just upstream from the Independence well field. 
Table 12. Water quality of samples from the Missouri River and samples collected at times that approximated the traveltime from the Missouri River to wells 7 and 38 and collector well 41.

[=, equals; mg/L, milligrams per Liter; --, no data; na, not applicable; $\mu \mathrm{S} / \mathrm{cm}$, microsiemens per centimeter; ${ }^{\circ} \mathrm{C}$, degrees Celsius; NTU, nephelometric turbidity units; nm, nanometer; $\mu \mathrm{g} / \mathrm{L}$, micrograms per liter; cysts/L, cysts per liter; oocysts./L oocysts per liter; MPN/L, most probable number per liter; col/100 mL, colonies per 100 milliliters; INF, infinite log removal too large to calculate]

\begin{tabular}{|c|c|c|c|c|c|c|c|c|c|c|c|c|c|c|c|c|}
\hline \multirow[b]{2}{*}{$\begin{array}{l}\text { Missouri River } \\
\text { sample date }\end{array}$} & \multirow{2}{*}{$\begin{array}{c}\text { (Gro } \\
\text { Oct } \\
29 \\
2003\end{array}$} & d-wate & travelt & $\begin{array}{l}\text { Well } 7 \\
\text { e from } 1\end{array}$ & ssouri & rer $=12$ & ays) & \multicolumn{2}{|c|}{$\begin{array}{c}\text { Well 38 } \\
\text { (Ground-water } \\
\text { traveltime from } \\
\text { Missouri River }=270 \\
\text { days) }\end{array}$} & \multicolumn{7}{|c|}{$\begin{array}{c}\text { Collector well } 41 \\
\text { (Ground-water traveltime from Missouri River }=\mathbf{3 0} \text { days) }\end{array}$} \\
\hline & & $\begin{array}{c}\text { Oct } \\
29 \\
2003\end{array}$ & $\begin{array}{c}\text { Dec } \\
17 \\
2003\end{array}$ & $\begin{array}{c}\text { Dec } \\
17 \\
2003\end{array}$ & $\begin{array}{c}\text { Jan } \\
28 \\
2004\end{array}$ & $\begin{array}{c}\text { Feb } \\
24 \\
2004\end{array}$ & $\begin{array}{c}\text { Apr } \\
27 \\
2004\end{array}$ & $\begin{array}{c}\text { Oct } \\
29 \\
2003\end{array}$ & $\begin{array}{c}\text { Dec } \\
17 \\
2003\end{array}$ & $\begin{array}{c}\text { Oct } \\
29 \\
2003\end{array}$ & $\begin{array}{c}\text { Dec } \\
17 \\
2003\end{array}$ & $\begin{array}{c}\text { Jan } \\
28 \\
2004\end{array}$ & $\begin{array}{c}\text { Feb } \\
24 \\
2004\end{array}$ & $\begin{array}{c}\text { Mar } \\
30 \\
2004\end{array}$ & $\begin{array}{c}\text { Apr } \\
27 \\
2004\end{array}$ & $\begin{array}{c}\text { May } \\
26 \\
2004\end{array}$ \\
\hline Well sample date & $\begin{array}{c}\text { Feb } \\
25 \\
2004\end{array}$ & $\begin{array}{c}\text { Mar } \\
31 \\
2004\end{array}$ & $\begin{array}{c}\text { Mar } \\
31 \\
2004\end{array}$ & $\begin{array}{c}\text { May } \\
4 \\
2004\end{array}$ & $\begin{array}{c}\text { May } \\
26 \\
2004\end{array}$ & $\begin{array}{c}\text { Jul } \\
13 \\
2004\end{array}$ & $\begin{array}{c}\text { Sep } \\
8 \\
2004\end{array}$ & $\begin{array}{c}\text { Jul } \\
13 \\
2004\end{array}$ & $\begin{array}{c}\text { Sep } \\
8 \\
2004\end{array}$ & $\begin{array}{c}\text { Nov } \\
19 \\
2003\end{array}$ & $\begin{array}{c}\text { Jan } \\
28 \\
2004\end{array}$ & $\begin{array}{c}\text { Feb } \\
25 \\
2004\end{array}$ & $\begin{array}{c}\text { Mar } \\
30 \\
2004\end{array}$ & $\begin{array}{c}\text { May } \\
4 \\
2004\end{array}$ & $\begin{array}{c}\text { May } \\
26 \\
2004\end{array}$ & $\begin{array}{c}\text { Jul } \\
13 \\
2004\end{array}$ \\
\hline $\begin{array}{l}\text { Days between } \\
\text { samples }\end{array}$ & 119 & 154 & 105 & 139 & 119 & 140 & 134 & 258 & 266 & 21 & 42 & 28 & 35 & 35 & 29 & 48 \\
\hline
\end{tabular}

River

Well

Change

Percent change

\section{River}

Well

Change

\section{River}

Well

Change

Percent change

10.5
1.4
-9.2
-87.

$\begin{array}{lccrr}\text { River } & 15 & 15 & 3.5 & 3.5 \\ \text { Well } & 16.8 & 13.2 & 13.2 & 12.4 \\ \text { Change } & 1.8 & -1.8 & 9.7 & 8.9 \\ \text { Percent change } & 12.0 & -12.0 & 277 & 254\end{array}$

Percent change
Dissolved oxygen, in $\mathrm{mg} / \mathrm{L}$

$\begin{array}{rrccr}12.9 & 10.8 & 9.5 & 10.5 & 13 \\ 1.8 & 1.7 & 1 & 0 & 0 \\ -11.1 & -9.1 & -8.5 & -10.5 & -13 \\ -86.4 & -84.3 & -89.5 & -100 & -100\end{array}$

$\mathrm{pH}$

$\begin{array}{rrr}8.5 & 8.2 & 8.5 \\ 7.6 & 7.7 & 7.1 \\ -0.9 & -0.5 & -1.4\end{array}$

$\begin{array}{rr}8.5 & 7.9 \\ 7.7 & 7.1 \\ -0.8 & -0.8\end{array}$

$\begin{array}{ccccc}859 & 682 & 722 & 740 & 876 \\ 679 & 661 & 624 & 701 & 707 \\ -180 & -21 & -98 & -39 & -169 \\ -21.0 & -3.1 & -13.6 & -5.3 & -19.3\end{array}$

Temperature, in ${ }^{\circ} \mathrm{C}$
Specific conductance, in $\mu \mathrm{S} / \mathrm{cm}$

$\begin{array}{rcr}10.5 & 13 & 12.9 \\ 0.2 & 0.3 & 0.6 \\ -10.3 & -12.7 & -12.4 \\ -98.1 & -97.6 & -95.7\end{array}$

10.8

4.3
-6.5

$\begin{array}{lll}7.2 & 9.5 & 3.9\end{array}$

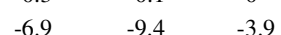

$\begin{array}{lll}-95.8 & -99.2 & -100\end{array}$

$\begin{array}{rrrrrrr}8.5 & 7.9 & 8.5 & 8.2 & 7.8 & 8.5 & 7.8 \\ 7.2 & 7.5 & 7.7 & 7.4 & 7.1 & 7.6 & 7.6 \\ -1.3 & -.4 & -.8 & -0.8 & -.7 & -.9 & -0.2\end{array}$

$\begin{array}{rrrrrrr}-1.3 & -.4 & -.8 & -0.8 & -.7 & -.9 & -0.2\end{array}$

$\begin{array}{rrrrr}.5 & 4 & 16.4 & 15 & 3.5 \\ 7.8 & 8.5 & 13.9 & 13.6 & 13.1 \\ 7.3 & 4.5 & -2.5 & -1.4 & 9.6 \\ 1,460 & 112 & -15.2 & -9.3 & 274\end{array}$

$\begin{array}{lll}1,460 & 112 & -15.2\end{array}$

$-9.3$

274

3.5
9.1
9

$\begin{array}{ccccccr}740 & 876 & 859 & 682 & 562 & 722 & 622 \\ 711 & 773 & 800 & 701 & 723 & 668 & 622 \\ -29 & -103 & -59 & 19 & 161 & -54 & 0 \\ -3.9 & -11.8 & -6.9 & 2.8 & 28.6 & -7.5 & 0\end{array}$

$\begin{array}{rrrrrrr}15 & 3.5 & .5 & 4 & 14 & 16.4 & 22.5 \\ 18.3 & 10.9 & 8.6 & 8.8 & 14.6 & 16.7 & 21.6 \\ 3.3 & 7.4 & 8.1 & 4.8 & .6 & .3 & -.9 \\ 22.0 & 211 & 1,620 & 120 & 4.3 & 1.8 & -4.0\end{array}$


Table 12. Water quality of samples from the Missouri River and samples collected at times that approximated the traveltime from the Missouri River to wells 7 and 38 and collector well 41.-Continued

[=, equals; mg/L, milligrams per Liter; --, no data; na, not applicable; $\mu \mathrm{S} / \mathrm{cm}$, microsiemens per centimeter; ${ }^{\circ} \mathrm{C}$, degrees Celsius; NTU, nephelometric turbidity units; nm, nanometer; $\mu \mathrm{g} / \mathrm{L}$, micrograms per liter; cysts/L, cysts per liter; oocysts./L oocysts per liter; MPN/L, most probable number per liter; col/100 mL, colonies per 100 milliliters; INF, infinite log removal too large to calculate]

\begin{tabular}{|c|c|c|c|c|c|c|c|c|c|c|c|c|c|c|c|c|}
\hline \multirow[b]{2}{*}{$\begin{array}{l}\text { Missouri River } \\
\text { sample date }\end{array}$} & \multicolumn{7}{|c|}{$\begin{array}{c}\text { Well } 7 \\
\text { (Ground-water traveltime from Missouri River }=120 \text { days) }\end{array}$} & \multicolumn{2}{|c|}{$\begin{array}{c}\text { Well } 38 \\
\text { (Ground-water } \\
\text { traveltime from } \\
\text { Missouri River }=270 \\
\text { days) }\end{array}$} & \multicolumn{7}{|c|}{$\begin{array}{c}\text { Collector well } 41 \\
\text { (Ground-water traveltime from Missouri River }=\mathbf{3 0} \text { days) }\end{array}$} \\
\hline & $\begin{array}{c}0 c t \\
29 \\
2003\end{array}$ & $\begin{array}{l}\text { Oct } \\
29\end{array}$ & $\begin{array}{c}\text { Dec } \\
17 \\
2003\end{array}$ & $\begin{array}{c}\text { Dec } \\
17 \\
2003\end{array}$ & $\begin{array}{c}\text { Jan } \\
28\end{array}$ & $\begin{array}{c}\text { Feb } \\
24\end{array}$ & $\begin{array}{c}\text { Apr } \\
27\end{array}$ & $\begin{array}{c}\text { Oct } \\
29 \\
2002\end{array}$ & $\begin{array}{c}\text { Dec } \\
17 \\
2003\end{array}$ & $\begin{array}{c}\text { Oct } \\
29 \\
2003\end{array}$ & $\begin{array}{c}\text { Dec } \\
17\end{array}$ & $\begin{array}{l}\text { Jan } \\
28\end{array}$ & $\begin{array}{c}\text { Feb } \\
24\end{array}$ & $\begin{array}{c}\text { Mar } \\
30\end{array}$ & $\begin{array}{c}\text { Apr } \\
27\end{array}$ & $\begin{array}{l}\text { May } \\
26\end{array}$ \\
\hline Well sample date & $\begin{array}{c}\text { Feb } \\
25 \\
2004\end{array}$ & $\begin{array}{c}\text { Mar } \\
31 \\
2004\end{array}$ & $\begin{array}{c}\text { Mar } \\
31 \\
2004\end{array}$ & $\begin{array}{c}\text { May } \\
4 \\
2004\end{array}$ & $\begin{array}{c}\text { May } \\
26 \\
2004\end{array}$ & $\begin{array}{c}\text { Jul } \\
13 \\
2004\end{array}$ & $\begin{array}{c}\text { Sep } \\
8 \\
2004\end{array}$ & $\begin{array}{c}\text { Jul } \\
13 \\
2004\end{array}$ & $\begin{array}{c}\text { Sep } \\
8 \\
2004\end{array}$ & $\begin{array}{c}\text { Nov } \\
19 \\
2003\end{array}$ & $\begin{array}{c}\text { Jan } \\
28 \\
2004\end{array}$ & $\begin{array}{c}\text { Feb } \\
25 \\
2004\end{array}$ & $\begin{array}{c}\text { Mar } \\
30 \\
2004\end{array}$ & $\begin{array}{c}\text { May } \\
4 \\
2004\end{array}$ & $\begin{array}{c}\text { May } \\
26 \\
2004\end{array}$ & $\begin{array}{c}\text { Jul } \\
13 \\
2004\end{array}$ \\
\hline $\begin{array}{l}\text { Days between } \\
\text { samples }\end{array}$ & 119 & 154 & 105 & 139 & 119 & 140 & 134 & 258 & 266 & 21 & 42 & 28 & 35 & 35 & 29 & 48 \\
\hline
\end{tabular}

River

Well

Change

Percent change

Log Removal

River
Well

Change

Percent change

River

Well

Change

Percent change

River

Well

Change

Percent change

\begin{tabular}{rr}
\multicolumn{1}{c}{42} & 61.2 \\
3.3 & 3.3 \\
-38.7 & -57.9 \\
-92.1 & -94.6 \\
1.1 & 1.3
\end{tabular}

Turbidity, in NTU

Dissolved organic carbon, in $\mathrm{mg} / \mathrm{L}$

$\begin{array}{rrcc}3.1 & 3.1 & 2.9 & 2.9 \\ 2.3 & 1.9 & 1.9 & 1.9 \\ -.8 & -1.2 & -1 & -1 \\ -25.8 & -38.7 & -34.5 & -34.5\end{array}$

$\begin{array}{ll}3.9 & 3 \\ 2.3 & 2.5\end{array}$

$-41.0$

$-16.7$

Ultraviolet absorbance at $254 \mathrm{~nm}$

$\begin{array}{cccc}0.056 & -- & 0.63 & 0.063 \\ .052 & -- & .039 & .046 \\ -.004 & -- & -.591 & -.017 \\ -7.1 & -- & -93.8 & -27.0\end{array}$

0.063
.043
-.02
-31.7

$\begin{array}{rc}0.091 & 0.068 \\ .041 & .079 \\ -.05 & .011 \\ -54.9 & 16.2\end{array}$

$\begin{array}{lc}0.056 & 0.063 \\ .061 & .074 \\ .005 & .011 \\ 8.9 & 17.5\end{array}$

Specific ultraviolet absorbance at $254 \mathrm{~nm}$

$\begin{array}{rrrr}1.81 & 1.81 & 2.17 & 2.17 \\ 2.26 & 2.05 & 2.05 & 2.42 \\ .45 & .24 & -.12 & .25 \\ 25.2 & 13.3 & -5.5 & 11.5\end{array}$

$\begin{array}{ccccc}1.75 & 2.33 & 2.27 & 1.81 & 2.17 \\ 2.69 & 1.78 & 3.16 & 2.18 & 2.96 \\ .94 & -.55 & .89 & .37 & .79 \\ 53.6 & -23.6 & 39.4 & 20.6 & 36.3\end{array}$

$\begin{array}{rc}42 & 61.2 \\ 6.7 & 8 \\ -35.3 & -53.2 \\ -84.1 & -86.9 \\ 0.8 & 0.9\end{array}$

\begin{tabular}{crrrr}
18.3 & \multicolumn{1}{c}{573} & \multicolumn{1}{c}{1006} & \multicolumn{1}{c}{45} & -- \\
2 & .8 & .33 & .6 & -- \\
-16.3 & -572.2 & 1005.7 & -44.4 & -- \\
-89.1 & -99.9 & -100.0 & -98.7 & -- \\
1.0 & 2.8 & 3.5 & 1.9 & --
\end{tabular}

$\begin{array}{rrrrccr}3.1 & 2.9 & 3.6 & 3.9 & 4 & 3 & 3.2 \\ 2.3 & 2.7 & 2.3 & 2.4 & 2.1 & 2 & 2.4 \\ -.8 & -.2 & -1.3 & -1.5 & -1.9 & -1 & -.8 \\ -25.8 & -6.9 & -36.1 & -38.5 & -47.5 & -33.3 & -25.0\end{array}$

$\begin{array}{lllllll}0.056 & 0.063 & 0.063 & 0.091 & 0.12 & 0.068 & 0.102\end{array}$

$\begin{array}{rrrrrrr}.064 & .047 & .056 & .06 & .06 & .054 & .058\end{array}$

$\begin{array}{lllllll}.008 & -.016 & -.007 & -.031 & -.06 & -.014 & -.044\end{array}$

$\begin{array}{lllllll}14.3 & -25.4 & -11.1 & -34.1 & -50.0 & -20.6 & -43.1\end{array}$

$\begin{array}{rrrrrrr}1.81 & 2.17 & 1.75 & 2.33 & 3.00 & 2.27 & 3.19 \\ 2.78 & 1.74 & 2.43 & 2.50 & 2.86 & 2.70 & 2.42 \\ .98 & -.43 & .68 & .17 & -.14 & .43 & -.77 \\ 54.0 & -19.9 & 39.1 & 7.1 & -4.8 & 19.1 & -24.2\end{array}$


Table 12. Water quality of samples from the Missouri River and samples collected at times that approximated the traveltime from the Missouri River to wells 7 and 38 and collector well 41.-Continued

[=, equals; mg/L, milligrams per Liter; --, no data; na, not applicable; $\mu \mathrm{S} / \mathrm{cm}$, microsiemens per centimeter; ${ }^{\circ} \mathrm{C}$, degrees Celsius; NTU, nephelometric turbidity units; nm, nanometer; $\mu \mathrm{g} / \mathrm{L}$, micrograms per liter; cysts/L, cysts per liter; oocysts./L oocysts per liter; MPN/L, most probable number per liter; col/100 mL, colonies per 100 milliliters; INF, infinite log removal too large to calculate]

\begin{tabular}{|c|c|c|c|c|c|c|c|c|c|c|c|c|c|c|c|c|}
\hline \multirow[b]{2}{*}{$\begin{array}{l}\text { Missouri River } \\
\text { sample date }\end{array}$} & \multirow{2}{*}{$\begin{array}{l}\text { (Gro } \\
\text { Oct } \\
29 \\
2003\end{array}$} & d-wat & travelt & $\begin{array}{l}\text { Well } 7 \\
\text { e from }\end{array}$ & souri F & rer $=12$ & ays) & \multicolumn{2}{|c|}{$\begin{array}{c}\text { Well 38 } \\
\text { (Ground-water } \\
\text { traveltime from } \\
\text { Missouri River }=270 \\
\text { days) }\end{array}$} & \multicolumn{7}{|c|}{$\begin{array}{c}\text { Collector well } 41 \\
\text { (Ground-water traveltime from Missouri River }=\mathbf{3 0} \text { days) }\end{array}$} \\
\hline & & $\begin{array}{c}\text { Oct } \\
29 \\
2003\end{array}$ & $\begin{array}{c}\text { Dec } \\
17 \\
2003\end{array}$ & $\begin{array}{c}\text { Dec } \\
17 \\
2003\end{array}$ & $\begin{array}{c}\text { Jan } \\
28 \\
2004\end{array}$ & $\begin{array}{c}\text { Feb } \\
24 \\
2004\end{array}$ & $\begin{array}{c}\text { Apr } \\
27 \\
2004\end{array}$ & $\begin{array}{c}\text { Oct } \\
29 \\
2003\end{array}$ & $\begin{array}{c}\text { Dec } \\
17 \\
2003\end{array}$ & $\begin{array}{c}\text { Oct } \\
29 \\
2003\end{array}$ & $\begin{array}{c}\text { Dec } \\
17 \\
2003\end{array}$ & $\begin{array}{c}\text { Jan } \\
28 \\
2004\end{array}$ & $\begin{array}{c}\text { Feb } \\
24 \\
2004\end{array}$ & $\begin{array}{c}\text { Mar } \\
30 \\
2004\end{array}$ & $\begin{array}{c}\text { Apr } \\
27 \\
2004\end{array}$ & $\begin{array}{c}\text { May } \\
26 \\
2004\end{array}$ \\
\hline Well sample date & $\begin{array}{c}\text { Feb } \\
25 \\
2004\end{array}$ & $\begin{array}{c}\text { Mar } \\
31 \\
2004\end{array}$ & $\begin{array}{c}\text { Mar } \\
31 \\
2004\end{array}$ & $\begin{array}{c}\text { May } \\
4 \\
2004\end{array}$ & $\begin{array}{c}\text { May } \\
26 \\
2004\end{array}$ & $\begin{array}{c}\text { Jul } \\
13 \\
2004\end{array}$ & $\begin{array}{c}\text { Sep } \\
8 \\
2004\end{array}$ & $\begin{array}{c}\text { Jul } \\
13 \\
2004\end{array}$ & $\begin{array}{c}\text { Sep } \\
8 \\
2004\end{array}$ & $\begin{array}{c}\text { Nov } \\
19 \\
2003\end{array}$ & $\begin{array}{c}\text { Jan } \\
28 \\
2004\end{array}$ & $\begin{array}{c}\text { Feb } \\
25 \\
2004\end{array}$ & $\begin{array}{c}\text { Mar } \\
30 \\
2004\end{array}$ & $\begin{array}{c}\text { May } \\
4 \\
2004\end{array}$ & $\begin{array}{c}\text { May } \\
26 \\
2004\end{array}$ & $\begin{array}{c}\text { Jul } \\
13 \\
2004\end{array}$ \\
\hline $\begin{array}{l}\text { Days between } \\
\text { samples }\end{array}$ & 119 & 154 & 105 & 139 & 119 & 140 & 134 & 258 & 266 & 21 & 42 & 28 & 35 & 35 & 29 & 48 \\
\hline
\end{tabular}

River

Well

Change

Percent change

River

Well

Change

Percent change

Well

Change

Percent change

River

Well

Change

Percent change
Chlorophyll $a$, in $\mu \mathrm{g} / \mathrm{L}$

44
.1
-43.9
-99.8

Tannin and lignin, in $\mathrm{mg} / \mathrm{L}$

$\begin{array}{cccc}3.5 & -- & 2.4 & - \\ 1.5 & -- & 1.5 & - \\ -2 & -- & -.9 & - \\ -57 & -- & -38 & --\end{array}$

Dissolved ammonia, in $\mathrm{mg} / \mathrm{L}$

\begin{tabular}{ccccc}
0.35 & 0.21 & 0.08 & - & -- \\
.06 & .05 & .05 & -- & -- \\
-.29 & -.16 & -.03 & -- & - \\
-83 & -76 & -38 & -- & - \\
\multicolumn{5}{c}{ Dissolved nitrite + nitrate, in $\mathrm{mg} / \mathrm{L}$} \\
0.97 & 1.4 & 0.68 & -- & -- \\
.02 & .02 & .06 & -- & - \\
-.95 & -1.38 & -.62 & - & - \\
-98 & -99 & -91 & -- & -
\end{tabular}


Table 12. Water quality of samples from the Missouri River and samples collected at times that approximated the traveltime from the Missouri River to wells 7 and 38 and collector well 41.-Continued

[=, equals; mg/L, milligrams per Liter; --, no data; na, not applicable; $\mu \mathrm{S} / \mathrm{cm}$, microsiemens per centimeter; ${ }^{\circ} \mathrm{C}$, degrees Celsius; NTU, nephelometric turbidity units; nm, nanometer; $\mu \mathrm{g} / \mathrm{L}$, micrograms per liter; cysts/L, cysts per liter; oocysts./L oocysts per liter; MPN/L, most probable number per liter; col/100 mL, colonies per 100 milliliters; INF, infinite log removal too large to calculate]

\begin{tabular}{|c|c|c|c|c|c|c|c|c|c|c|c|c|c|c|c|c|}
\hline \multirow[b]{2}{*}{$\begin{array}{l}\text { Missouri River } \\
\text { sample date }\end{array}$} & \multirow{2}{*}{$\begin{array}{c}\text { (Gr } \\
\text { Oct } \\
29 \\
2003\end{array}$} & d-wat & travelt & $\begin{array}{l}\text { Well } 7 \\
\text { e from }\end{array}$ & ssouri l & ver $=1$ & ays) & \multicolumn{2}{|c|}{$\begin{array}{c}\text { Well 38 } \\
\text { (Ground-water } \\
\text { traveltime from } \\
\text { Missouri River }=270 \\
\text { days) }\end{array}$} & \multicolumn{7}{|c|}{$\begin{array}{c}\text { Collector well } 41 \\
\text { (Ground-water traveltime from Missouri River }=30 \text { days) }\end{array}$} \\
\hline & & $\begin{array}{c}\text { Oct } \\
29 \\
2003\end{array}$ & $\begin{array}{c}\text { Dec } \\
17 \\
2003\end{array}$ & $\begin{array}{c}\text { Dec } \\
17 \\
2003\end{array}$ & $\begin{array}{c}\text { Jan } \\
28 \\
2004\end{array}$ & $\begin{array}{c}\text { Feb } \\
24 \\
2004\end{array}$ & $\begin{array}{c}\text { Apr } \\
27 \\
2004\end{array}$ & $\begin{array}{c}\text { Oct } \\
29 \\
2003\end{array}$ & $\begin{array}{c}\text { Dec } \\
17 \\
2003\end{array}$ & $\begin{array}{c}\text { Oct } \\
29 \\
2003\end{array}$ & $\begin{array}{c}\text { Dec } \\
17 \\
2003\end{array}$ & $\begin{array}{c}\text { Jan } \\
28 \\
2004\end{array}$ & $\begin{array}{c}\text { Feb } \\
24 \\
2004\end{array}$ & $\begin{array}{c}\text { Mar } \\
\mathbf{3 0} \\
\mathbf{2 0 0 4}\end{array}$ & $\begin{array}{c}\text { Apr } \\
27 \\
2004\end{array}$ & $\begin{array}{c}\text { May } \\
26 \\
2004\end{array}$ \\
\hline Well sample date & $\begin{array}{c}\text { Feb } \\
25 \\
2004\end{array}$ & $\begin{array}{c}\text { Mar } \\
31 \\
2004\end{array}$ & $\begin{array}{c}\text { Mar } \\
\mathbf{3 1} \\
2004\end{array}$ & $\begin{array}{c}\text { May } \\
4 \\
2004\end{array}$ & $\begin{array}{c}\text { May } \\
26 \\
2004\end{array}$ & $\begin{array}{c}\text { Jul } \\
13 \\
2004\end{array}$ & $\begin{array}{c}\text { Sep } \\
8 \\
2004\end{array}$ & $\begin{array}{c}\text { Jul } \\
13 \\
2004\end{array}$ & $\begin{array}{c}\text { Sep } \\
\mathbf{8} \\
2004\end{array}$ & $\begin{array}{c}\text { Nov } \\
19 \\
2003\end{array}$ & $\begin{array}{c}\text { Jan } \\
28 \\
2004\end{array}$ & $\begin{array}{c}\text { Feb } \\
25 \\
2004\end{array}$ & $\begin{array}{c}\text { Mar } \\
30 \\
2004\end{array}$ & $\begin{array}{c}\text { May } \\
4 \\
2004\end{array}$ & $\begin{array}{c}\text { May } \\
26 \\
2004\end{array}$ & $\begin{array}{c}\text { Jul } \\
13 \\
2004\end{array}$ \\
\hline $\begin{array}{l}\text { Days between } \\
\text { samples }\end{array}$ & 119 & 154 & 105 & 139 & 119 & 140 & 134 & 258 & 266 & 21 & 42 & 28 & 35 & 35 & 29 & 48 \\
\hline
\end{tabular}

River

Well

Change

Percent change

River

Well

Change

Percent change

Log Removal

River

Well

Change

Percent change

Log Removal

River

Well

Change

Percent change

Log Removal
Dissolved orthophosphate, in $\mathrm{mg} / \mathrm{L}$

$\begin{array}{rrrr}0.07 & 0.04 & -- & -- \\ .03 & .02 & -- & -- \\ -.04 & -.02 & -- & -- \\ -57 & -50 & -- & -\end{array}$

Giardia, in cysts/L

0.091
.002
-.089
-97.8
1.7

Total culturable virus, in MPN/L

$\begin{array}{cccc}44 & -- & 24.1 & - \\ .11 & -- & .13 & - \\ -43.89 & -- & -23.97 & - \\ -99.8 & -- & -99.5 & - \\ 2.6 & -- & 2.3 & -\end{array}$

24.1
10
-14.1
-58.5
0.4

$\begin{array}{cc}0.19 & 0.091 \\ .004 & .003 \\ -.186 & -.088 \\ -97.9 & -96.7 \\ 1.7 & 1.5\end{array}$

Total coliform, bacteria, in col/100 mL

$\begin{array}{rr}80,000 & 30,000 \\ 0 & 0 \\ -80,000 & -30,000 \\ -100 & -100 \\ \text { INF } & \text { INF }\end{array}$


Table 12. Water quality of samples from the Missouri River and samples collected at times that approximated the traveltime from the Missouri River to wells 7 and 38 and collector well 41.-Continued

[=, equals; mg/L, milligrams per Liter; --, no data; na, not applicable; $\mu \mathrm{S} / \mathrm{cm}$, microsiemens per centimeter; ${ }^{\circ} \mathrm{C}$, degrees Celsius; NTU, nephelometric turbidity units; nm, nanometer; $\mu \mathrm{g} / \mathrm{L}$, micrograms per liter; cysts/L, cysts per liter; oocysts./L oocysts per liter; MPN/L, most probable number per liter; col/100 mL, colonies per 100 milliliters; INF, infinite log removal too large to calculate]

\begin{tabular}{|c|c|c|c|c|c|c|c|c|c|c|c|c|c|c|c|c|}
\hline & (Gr & d-wate & r travelt & $\begin{array}{l}\text { Well } 7 \\
\text { e from I }\end{array}$ & ssouri f & ver $=1$ & ays) & $\begin{array}{r}\text { V } \\
\text { (Groı } \\
\text { trave } \\
\text { Missou }\end{array}$ & $\begin{array}{l}38 \\
\text { water } \\
\text { e from } \\
\text { ver }=270 \\
\text { ) }\end{array}$ & & und-we & r trave & $\begin{array}{l}\text { llector v } \\
\text { ime from }\end{array}$ & $\begin{array}{l}\text { Il } 41 \\
\text { Aissouri }\end{array}$ & er $=30$ & \\
\hline \multirow{3}{*}{$\begin{array}{l}\text { Missouri River } \\
\text { sample date }\end{array}$} & Oct & Oct & Dec & Dec & Jan & Feb & Apr & Oct & Dec & Oct & Dec & Jan & Feb & Mar & Apr & May \\
\hline & 29 & 29 & 17 & 17 & 28 & 24 & 27 & 29 & 17 & 29 & 17 & 28 & 24 & 30 & 27 & 26 \\
\hline & 2003 & 2003 & 2003 & 2003 & 2004 & 2004 & 2004 & 2003 & 2003 & 2003 & 2003 & 2004 & 2004 & 2004 & 2004 & 2004 \\
\hline \multirow[b]{4}{*}{$\begin{array}{c}\text { Days between } \\
\text { samples }\end{array}$} & Feb & Mar & Mar & May & May & Jul & Sep & Jul & Sep & Nov & Jan & Feb & Mar & May & May & Jul \\
\hline & 25 & 31 & 31 & 4 & 26 & 13 & 8 & 13 & 8 & 19 & 28 & 25 & 30 & 4 & 26 & 13 \\
\hline & 2004 & 2004 & 2004 & 2004 & 2004 & 2004 & 2004 & 2004 & 2004 & 2003 & 2004 & 2004 & 2004 & 2004 & 2004 & 2004 \\
\hline & 119 & 154 & 105 & 139 & 119 & 140 & 134 & 258 & 266 & 21 & 42 & 28 & 35 & 35 & 29 & 48 \\
\hline \multicolumn{17}{|c|}{ Total trihalomethane formation potential, in $\mu \mathrm{g} / \mathrm{L}$} \\
\hline River & 263.9 & 263.9 & 272 & -- & 401 & -- & -- & -- & -- & 263.9 & 272 & 401 & 594.1 & 762.9 & -- & -- \\
\hline Well & 160 & 152.8 & 152.8 & -- & 161.6 & -- & -- & -- & -- & 145 & 186 & 184.9 & 196 & 155 & -- & -- \\
\hline Change & -103.9 & -111.1 & -119.2 & -- & -239.4 & -- & -- & -- & -- & -118.9 & -86 & -216.1 & -398.1 & -607.9 & -- & -- \\
\hline Percent change & -39.4 & -42.1 & -43.8 & -- & -59.7 & -- & -- & -- & -- & -45.1 & -31.6 & -53.9 & -67.0 & -79.7 & -- & -- \\
\hline \multicolumn{17}{|c|}{ Total haloacetic acid formation potential, in $\mu \mathrm{g} / \mathrm{L}$} \\
\hline River & 294.3 & 294.3 & 105.9 & -- & 88.4 & -- & -- & -- & -- & 294.3 & 105.9 & 88.4 & $1,065.7$ & $1,622.4$ & -- & -- \\
\hline Well & 44.6 & 31.2 & 31.2 & -- & 33.1 & -- & -- & -- & -- & 40.7 & 34.5 & 44 & 42.2 & 44.3 & -- & -- \\
\hline Change & -249.7 & -263.1 & -74.7 & -- & -55.3 & -- & -- & -- & -- & -253.6 & -71.4 & -44.4 & $-1,023.5$ & $-1,578.1$ & -- & -- \\
\hline Percent change & -84.8 & -89.4 & -70.5 & -- & -62.6 & -- & -- & -- & -- & -86.2 & -67.4 & -50.2 & -96.0 & -97.3 & -- & -- \\
\hline
\end{tabular}



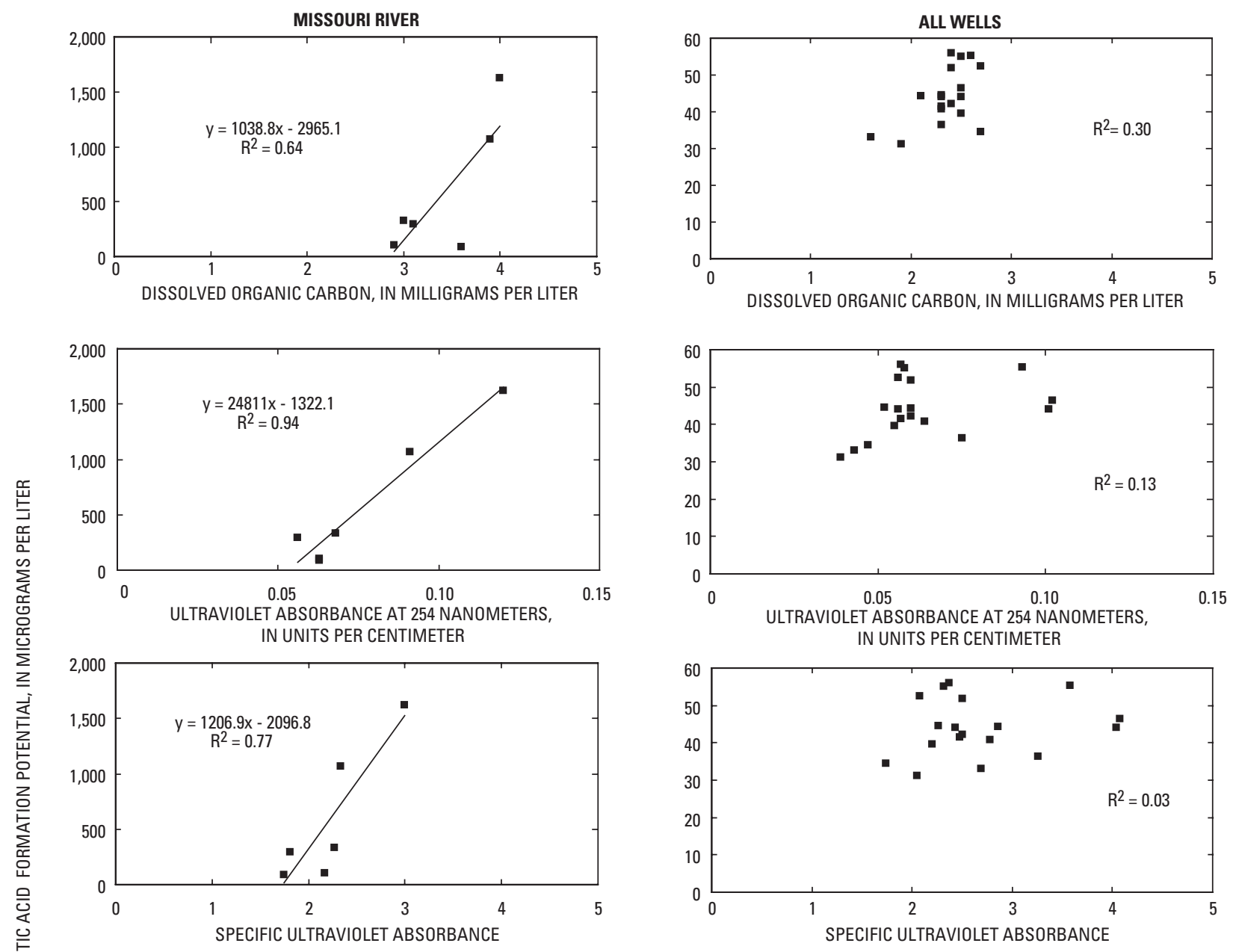
IN UNITS PER CENTIMETER
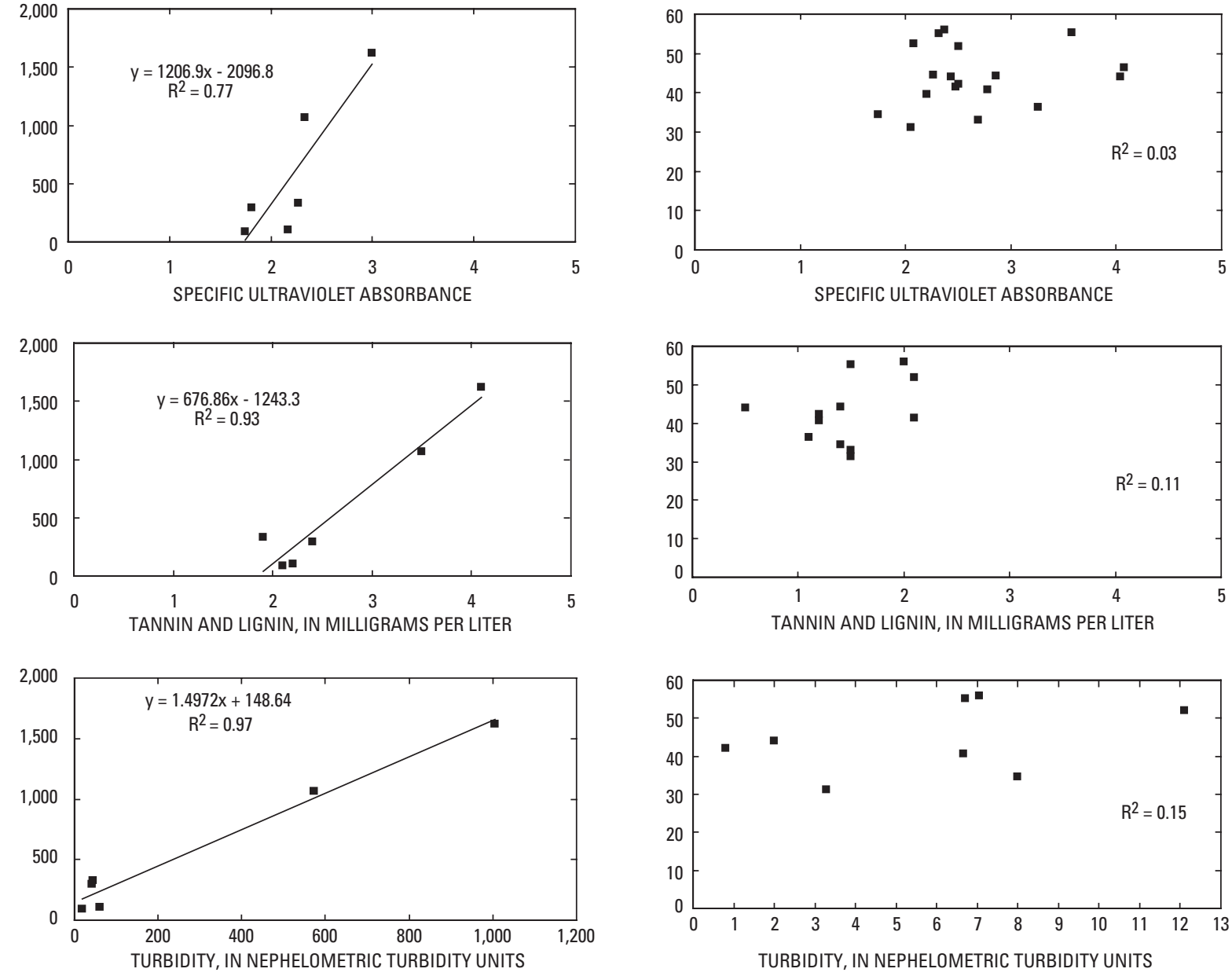

NOTE: Trend lines not plotted for correlation coefficient $\left(R^{2}\right)$ less than 0.5

Figure 19. Organic material, organic indicators, turbidity, and total haloacetic acid formation potential in water samples from the Missouri River and all wells. 

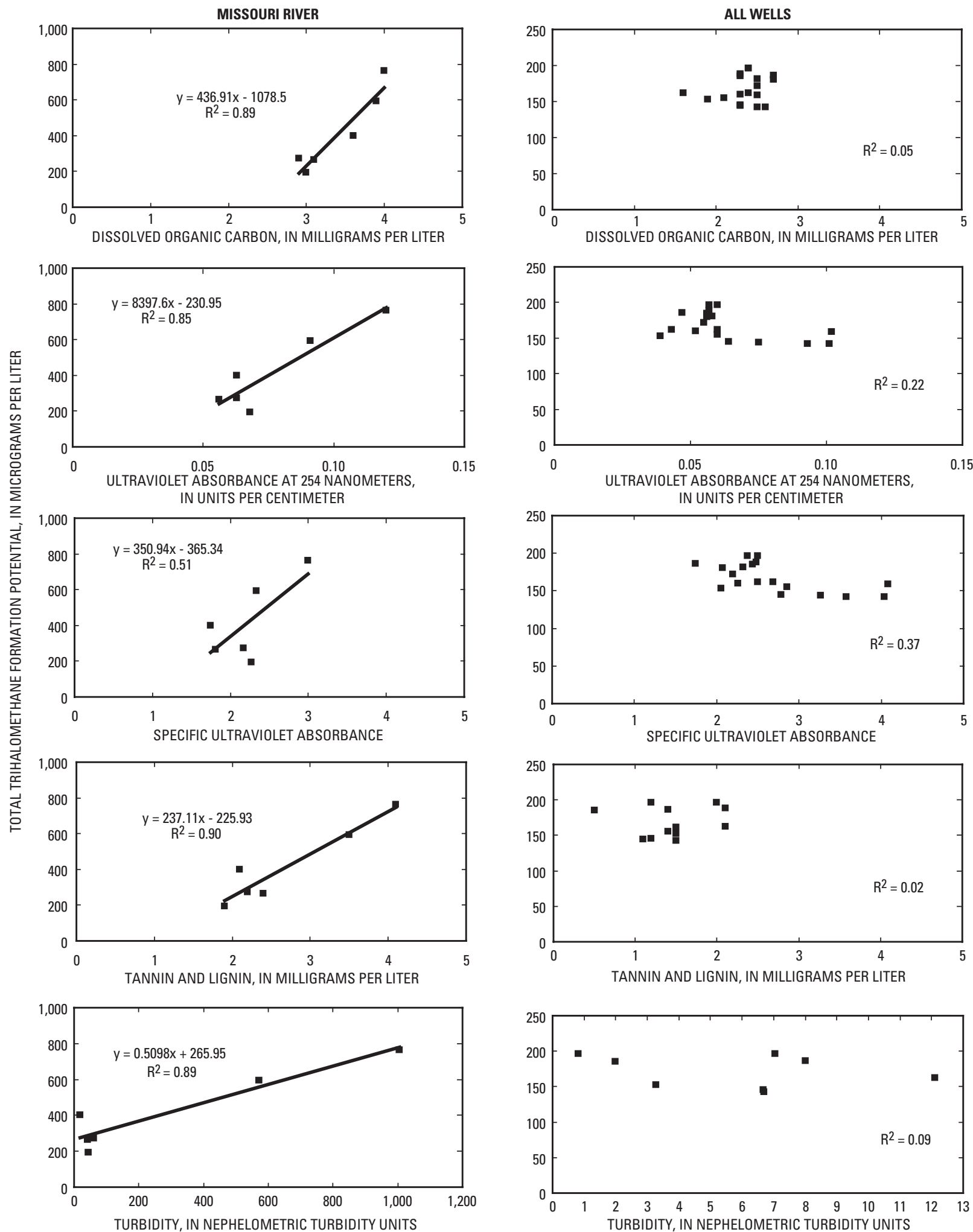

NOTE: Trend lines not plotted for correlation coefficient $\left(R^{2}\right)$ less than 0.5

Figure 20. Organic material, organic indicators, turbidity, and total haloacetic acid formation potential in water samples from the Missouri River and all wells. 
Organic wastewater compounds analyzed in samples collected from three points in a cross section of the Missouri River at Independence (south, middle, and north), from wells 7 and 38, and collector well 41 are listed in table 1. Although organic wastewater compounds were detected in the Missouri River and all sampled wells (table 13), the only compound with a quantified detection was phenol [1.8 $\mu \mathrm{g} / \mathrm{L}$ (micrograms per liter)] in well 7. For all other detections, the result was estimated (usually because concentrations were below the laboratory reporting limit) or the presence of the compound was verified, but not quantified by the laboratory. The small concentrations of organic wastewater compounds detected in the samples are interpreted in this report, but conclusions should be considered preliminary.

The organic wastewater compounds 4-nonylphenol, caffeine, N,N-diethyl-meta-toluamide (DEET), diethoxynonylphenol, ethoxyoctylphenol, and metolachlor were detected in three samples of the Missouri River collected on October 29, 2003. The sample sites were near the south bank, the middle, and the north bank of the Missouri River near the Independence well field (fig. 1). All organic wastewater compounds in Missouri River samples were detected at values less than the minimum reporting level; however, detections of some organic wastewater compounds were provided with an estimate of the concentration by the laboratory. Other organic wastewater compounds were identified in these samples, but their concentrations were not able to be estimated.

Estimated values for caffeine, diethoxynonylphenol, and metolachlor were larger near the south bank. Estimated values for para-nonylphenol, and caffeine were larger in the middle than near the north bank. The larger number of detections (table 13) near the south bank ( 6 detections) compared to the number of detections at the middle and north bank sites (4 detections each), combined with the larger estimated values for the south bank site, indicate that Missouri River water quality on the south side of the river probably was only moderately influenced by the south bank inflows to the river just upstream from the Independence well field (fig. 2).

On August 8, 9, and 10, 2005, dissolved oxygen, specific conductance, temperature, and turbidity were measured at depths less than $2 \mathrm{ft}$ in the Missouri River just upstream and adjacent to the Independence well field using a boat and a multi-parameter water-quality meter. Data from more than 4,280 locations were interpolated to produce maps showing the distribution of dissolved oxygen (fig. 21), specific conductance (fig. 22), temperature (fig. 23), and turbidity (fig. 24). Because the data were collected during 3 days and the value of each of these constituents changed constantly in the Missouri River, the interpolated maps contain abrupt changes in concentration or value at the interface between data collected on different days; however, the relative cross-sectional distribution of each constituent shown for each day's data can be compared to assess their overall pattern of distribution in the Missouri River. Dissolved oxygen (fig. 21) was smallest along the south bank of the Missouri River from the mouth of the Blue River downstream to the Independence well field. The smaller dissolved oxygen concentrations along the south bank may be caused by larger amounts of organic material supplied by south bank inflows from the sewage-treatment plants (figs. 2 and 21). In contrast to dissolved oxygen in the Missouri River, specific conductance remained largest along the south bank of the river (fig. 22). This most likely occurred because high-flow velocity in the center of the channel prevented south bank inflows from mixing across the channel in the Missouri River. Areas of relatively high specific conductance are located at the outfalls from the sewage-treatment plants, the mouth of the Blue River, along the south bank of the Missouri River, and the former oil refinery (figs. 2 and 22) indicating these inflows to the river may be at least moderately affecting the spatial distribution of riverwater quality near the well field. Water temperature (fig. 23) was highest along the south bank of the Missouri River and was lowest near the center of the river. Along the reach of the Missouri River adjacent to the Independence well field, the shallowest water also was located on the south bank where daytime heating and less mixing with colder deeper river water most likely was responsible for the higher water temperature. Turbidity (fig. 24) was largest in the middle of the river and smallest near the banks of the river. This distribution most likely was the result of water velocity and turbulent flow in the river. Water velocity is higher in the center of the river and more sediments are suspended in the water column there than in the shallow low-velocity water near the banks of the river. The distribution of turbidity did not seem to be affected by local inflows to the Missouri River in this reach.

Table 13. Dissolved organic wastewater compounds detected in water samples from the Missouri River, wells 7 and 38 , and collector well 41.

[--, not detected; all values in micrograms per liter; $\mathbf{M}$, presence of material verified but not quantified; E, estimated value]

\begin{tabular}{|c|c|c|c|c|c|c|}
\hline Site name & $\begin{array}{l}\text { Missouri River, } \\
\text { south }\end{array}$ & $\begin{array}{c}\text { Missouri River, } \\
\text { middle }\end{array}$ & $\begin{array}{c}\text { Missouri River, } \\
\text { north }\end{array}$ & Well 7 & Well 38 & Collector well 41 \\
\hline Sample date & $10 / 29 / 2003$ & $10 / 29 / 2003$ & $10 / 29 / 2003$ & $11 / 19 / 2003$ & $11 / 5 / 2003$ & $11 / 19 / 2003$ \\
\hline 1,4-Dichlorobenzenene & -- & -- & -- & M & -- & M \\
\hline 4-Nonylphenol & E 1 & E 1 & -- & -- & -- & -- \\
\hline Acetophenone & -- & -- & -- & E.2 & E. 1 & E. 2 \\
\hline AHTN & -- & -- & -- & $\mathrm{M}$ & -- & -- \\
\hline Caffeine & E.4 & E.2 & M & M & -- & -- \\
\hline Diethoxy-nonylphenol & E 3 & E 2 & E 2 & -- & -- & -- \\
\hline Ethoxy-octylphenol & M & -- & M & -- & -- & -- \\
\hline Metolachlor & E. 2 & E.1 & E.1 & M & -- & E.1 \\
\hline p-Cresol & -- & -- & -- & M & -- & -- \\
\hline Phenol & -- & -- & -- & 1.8 & E. 2 & -- \\
\hline Tributyl phosphate & -- & -- & -- & E. 1 & -- & -- \\
\hline Triphenyl phosphate & -- & -- & -- & M & -- & -- \\
\hline Tris(2-butoxyethyl)phosphate & -- & -- & -- & E. 2 & -- & -- \\
\hline NUMBER OF DETECTIONS & 6 & 4 & 4 & 11 & 2 & 3 \\
\hline
\end{tabular}




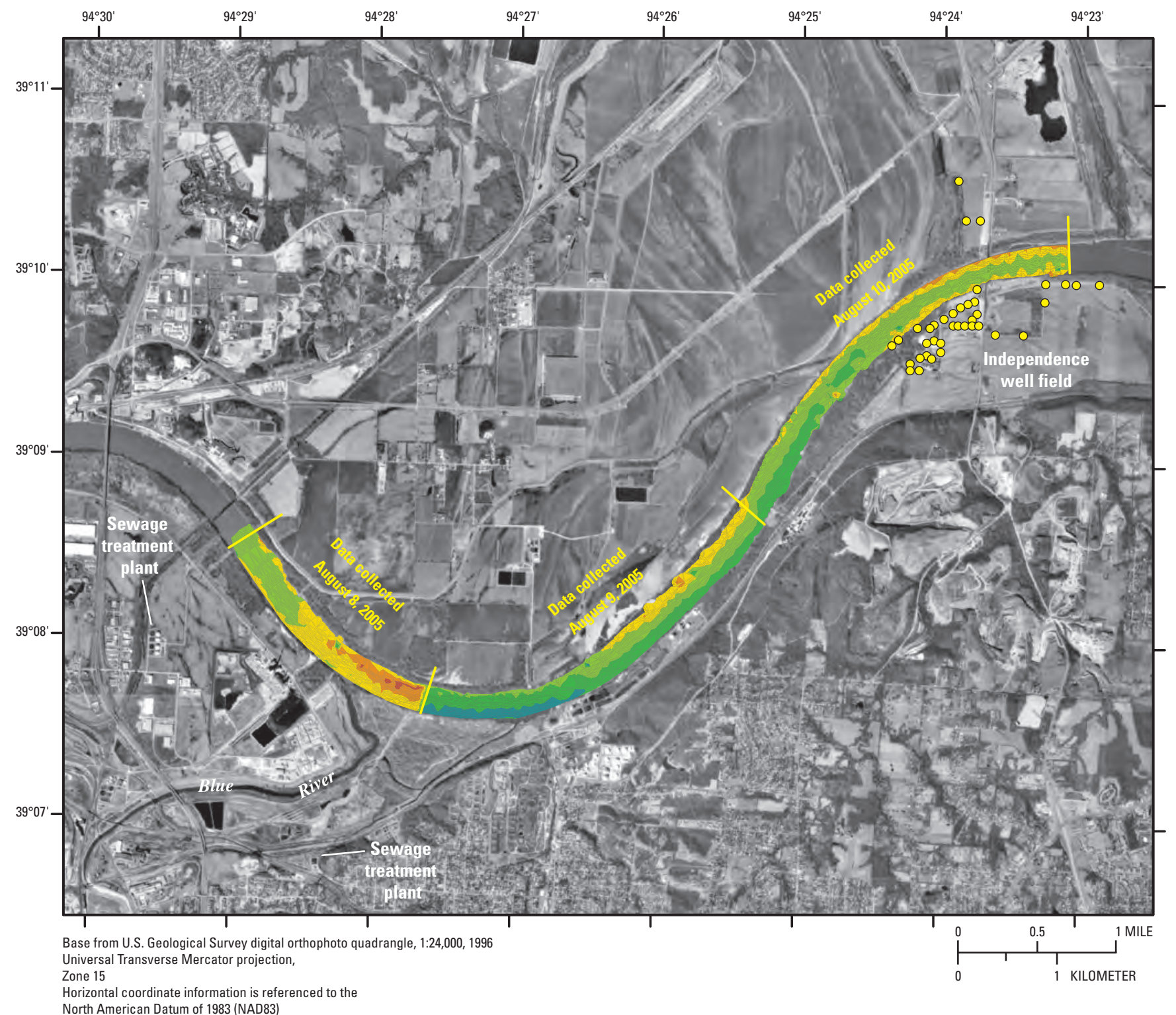

North American Datum of 1983 (NAD83)

EXPLANATION

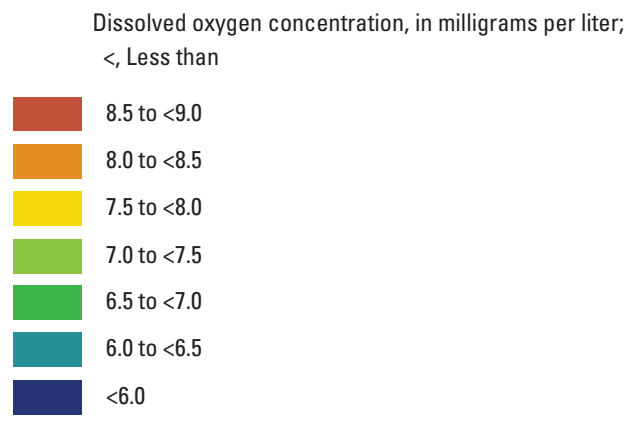

- Independence water-supply well

Figure 21. Dissolved oxygen concentration in the Missouri River near the Independence well field, August 2005. 


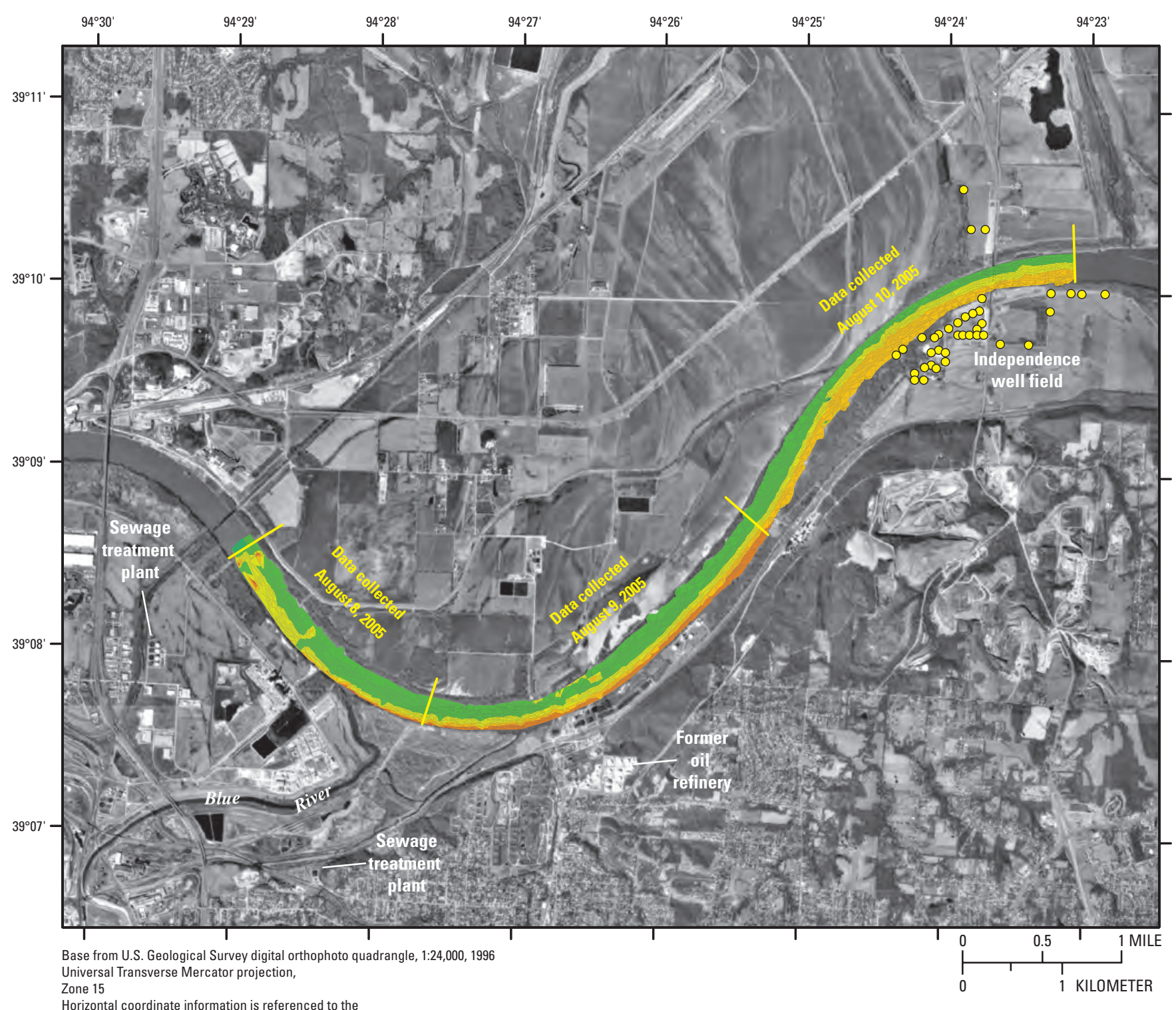

Zone 15

Horizontal coordinate information is referenced to the

North American Datum of 1983 (NAD83)

\section{EXPLANATION}

Specific conductance value, in microsiemens per centimeter at 25 degrees Celsius: $<$, Less than 840 to $<860$ 820 to $<840$ 800 to $<820$ 780 to $<800$ 760 to $<780$ 740 to $<760$ 720 to $<740$ 710 to $<720$

○ Independence water-supply well

Figure 22. Specific conductance values in the Missouri River near the Independence well field, August 2005. 


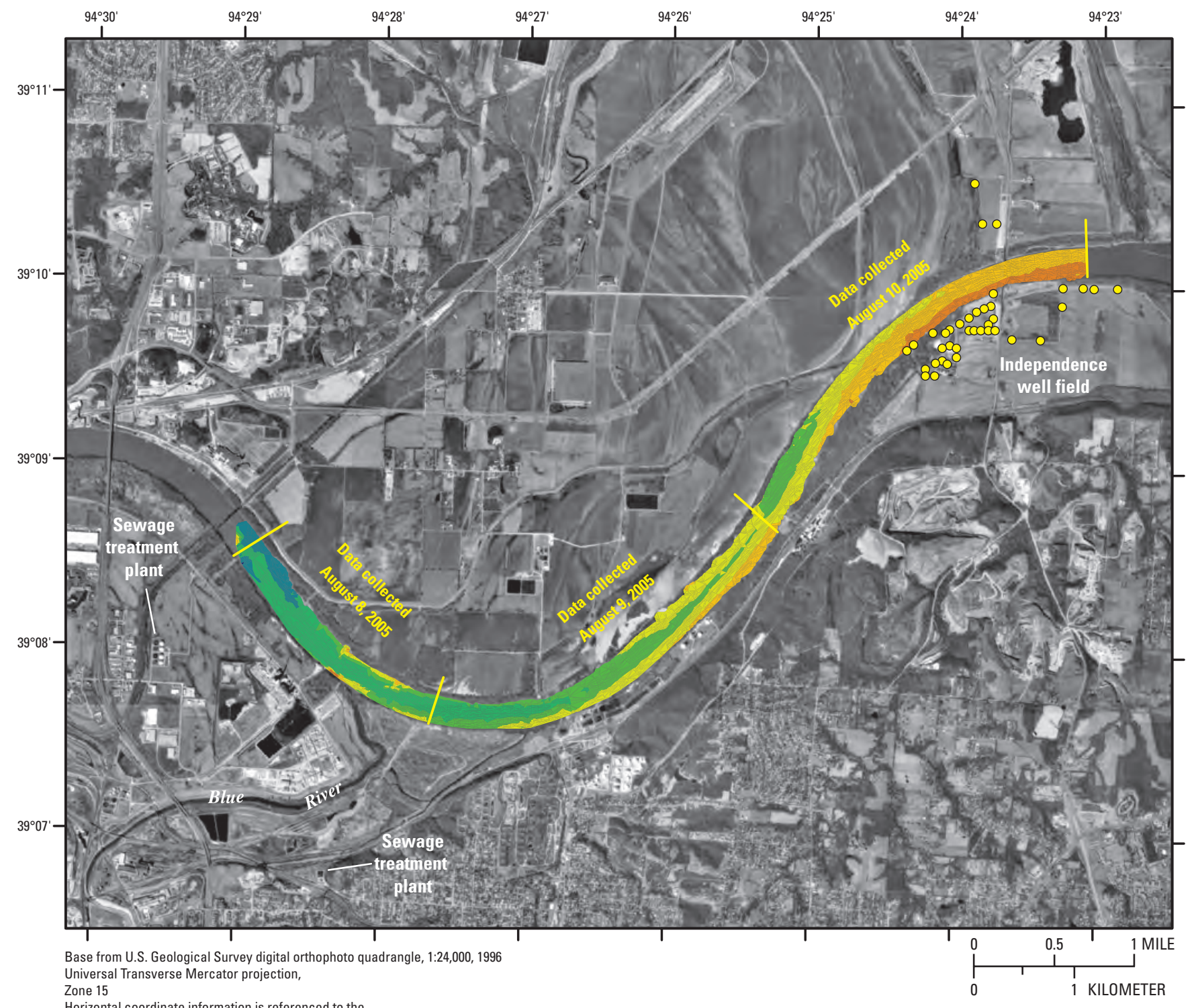

Horizontal coordinate information is referenced to the North American Datum of 1983 (NAD83)

EXPLANATION

$\begin{aligned} & \text { Temperature, in degrees Celsius; } \\ & <\text {, Less than }\end{aligned}$
31.0 to $<31.5$
30.5 to $<31.0$
30.0 to $<30.5$
29.5 to $<30.0$
29.0 to $<29.5$
28.5 to $<29.0$
28.0 to $<28.5$
$<28.0$

○ Independence water-supply well

Figure 23. Water temperature in the Missouri River near the Independence well field, August 2005. 


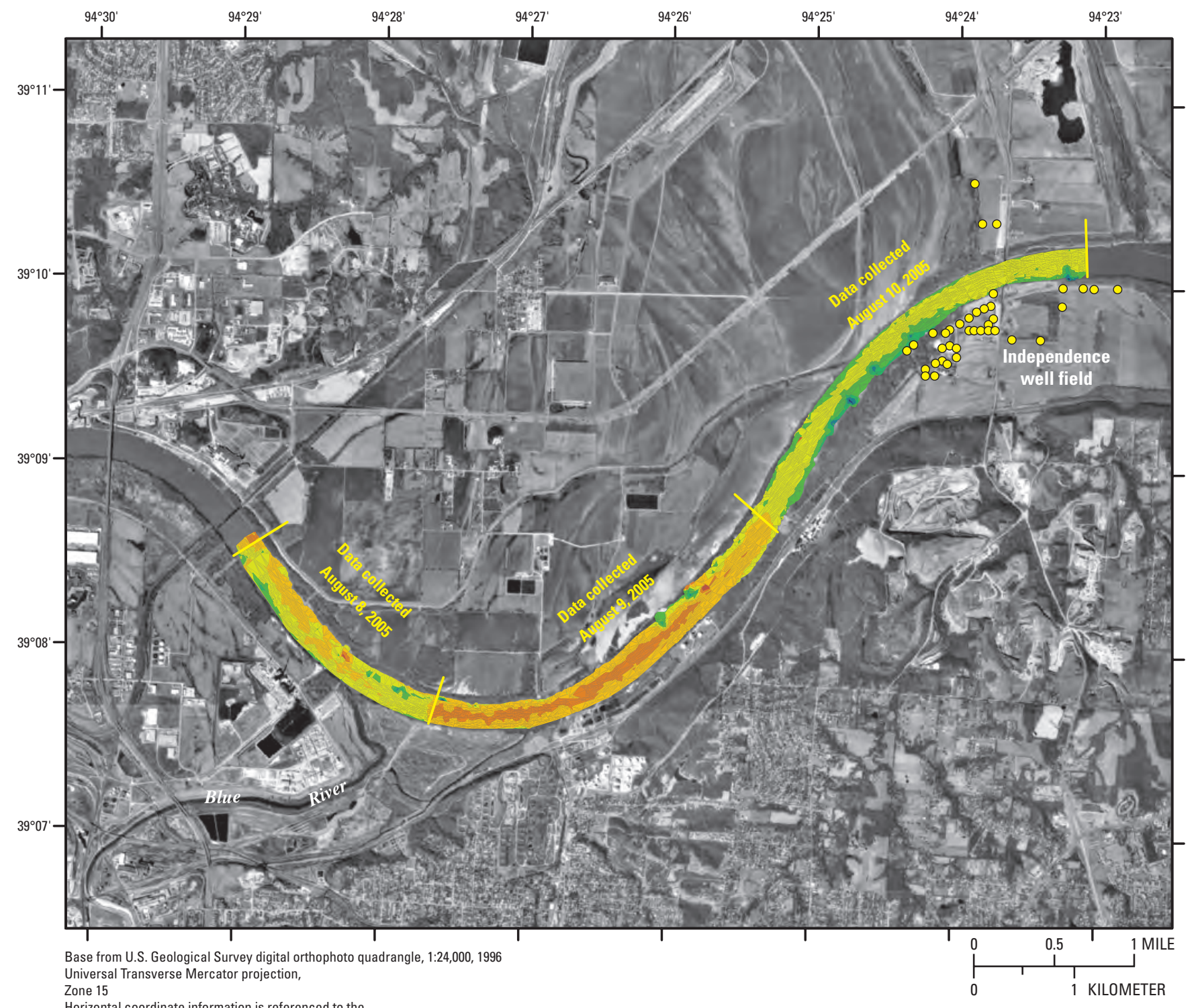

Horizontal coordinate information is referenced to the North American Datum of 1983 (NAD83)

EXPLANATION

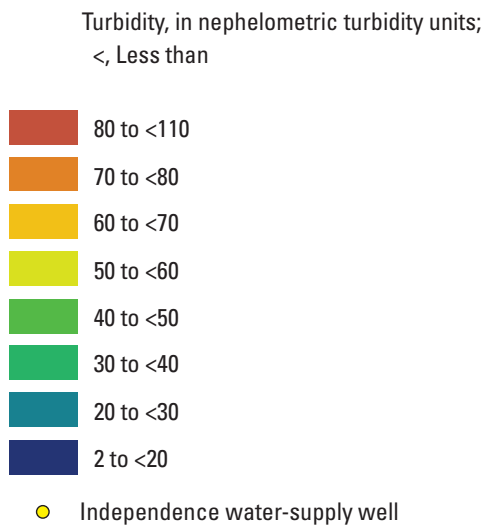

Figure 24. Turbidity values in the Missouri River near the Independence well field, August 2005. 


\section{Summary and Conclusions}

Riverbank filtration is the filtering of river water intended for public-water supply through alluvial deposits using infiltration galleries, pumping wells located near rivers, or horizontal collector wells located beneath rivers. Processes that occur during riverbank filtration include mechanical filtration, adsorption, biodegradation, ion exchange, and chemical reactions.

Changes in water quality in the Missouri River with time and discharge and in wells with time were determined from samples of the Missouri River near the Independence well field and from wells 7 and 38, and collector well 41. Median values of dissolved oxygen, $\mathrm{pH}$, turbidity, DOC, UV254, chlorophyll $a$, tannin and lignin, dissolved nitrite plus nitrate, dissolved nitrate, and dissolved orthophosphorous in Missouri River samples were larger than in samples from wells. Median specific conductance and SUVA values were slightly smaller for samples from the Missouri River than for samples from wells. Total coliform bacteria was detected in all water samples from the Missouri River, Cryptosporidium was detected only once in the Missouri River, Giardia was detected in four out of nine samples, and total culturable viruses were detected in all Missouri River water samples. No strong correlations were present between bacteria, protozoa, and viruses in water samples from the Missouri River and discharge, most likely because of the small data set. Total haloacetic acid formation potentials were substantially larger in samples from the Missouri River than for samples from the wells, and were related positively to discharge $\left(\mathrm{R}^{2}=0.72\right)$. Total trihalomethane formation potentials were substantially larger in samples from the Missouri River than in samples from the wells.

Median values of total coliform bacteria, Cryptosporidium, Giardia, and total culturable viruses decreased substantially between the Missouri River and wells, and were below the detection limit in all water samples from the wells. Total coliform bacteria decreased 100 percent, Cryptosporidium decreased between 96 and 100 percent, Giardia decrease between 97 and 100 percent, and total culturable viruses decreased between 85 and 100 percent.

The log removal for turbidity was 1.60. Turbidity in well water may be caused by precipitation of dissolved iron in the sample or other processes in the well. Actual log removal of particulates and colloids by riverbank filtration may be larger than indicated if turbidity measured in water samples from the wells is not related to turbidity in the Missouri River. The log removal for total coliform bacteria was greater than 4.57. Large concentrations of total coliform bacteria were detected in all Missouri River samples, but not detected in any water samples from the wells. Log removal for Cryptosporidium was greater than 1.67, and for Giardia was greater than 1.67; neither was detected in samples from the wells. Log removal for total culturable virus was greater than 1.15. Total culturable viruses were not detected in any samples from the wells, but were detected in all six samples from the Missouri River.
A comparison of river-water temperature changes with ground-water temperature changes was used to estimate the traveltime of water from the river to the pumping wells.

Approximate traveltimes from the river to the wells based on water temperature profiles were 4 months for well 7, 7 to 9 months for well 38, and 1 month for collector well 41. Average ground-water flow velocity between the Missouri River bed and the screened interval of each well was estimated using distances between the Missouri River and the midpoint of the screened interval and the estimated traveltimes. The rate of ground-water flow from the Missouri River to the wells ranged from 1.2 to 6.7 feet per day. These rates are less than rates typical of slow sand filters. Slower flow rates result in greater filtration, and indicate riverbank filtration at this site may be comparable to or more effective than a slow sand filter. Water-quality changes between samples from the Missouri River and well samples collected at times that approximated the traveltime from the Missouri River to wells indicate no clear relation between water-quality changes in the Missouri River and in wells for almost all constituents, although the temperature trend between the Missouri River and wells indicate the movement of water. The absence of any water-quality trends between the Missouri River and the pumping wells indicates the strong influence of riverbank filtration.

Minimum log removals were calculated for turbidity, total coliform bacteria, Giardia, and total culturable viruses between samples from the Missouri River and well samples collected at times that approximated the traveltime from the Missouri River to wells. Log removals for Cryptosporidium were not included because it was detected only once at the end of the sampling period, and no corresponding well samples were collected. Minimum log removals were infinite for total coliform bacteria, and ranged from 0.8 to 3.5 for turbidity, from 1.5 to 2.1 for Giardia, and from 0.4 to 2.6 for total culturable viruses.

Haloacetic acid and trihalomethane formation potentials in water samples from the Missouri River and wells were compared to determine their relation to changes in organic material, organic indicators, and turbidity. ultraviolet absorption at 254 nanometers $\left(\mathrm{R}^{2}=0.94\right)$, tannin and lignin $\left(\mathrm{R}^{2}=0.93\right)$, and turbidity $\left(\mathrm{R}^{2}=0.97\right)$ were the best predictors of haloacetic acid formation potential for water samples from the Missouri River. None of the variables were reliable predictors of haloacetic acid formation potential for water samples from all wells. For water samples from the Missouri River, DOC $\left(\mathrm{R}^{2}=0.89\right)$, ultraviolet absorption at 254 nanometers $\left(\mathrm{R}^{2}=0.85\right)$, tannin and lignin $\left(\mathrm{R}^{2}\right.$ $=0.90)$, and turbidity $\left(\mathrm{R}^{2}=0.89\right)$ were the best predictors of trihalomethane formation potential. None of the variables were reliable predictors for trihalomethane formation potential in water samples from all wells.

The cross-sectional distributions of specific conductance and organic wastewater compounds in the Missouri River near the Independence well field were determined to assess the influence of wastewater point sources along the Missouri River just upstream from the Independence well field. The larger number of detections (6) near the south bank compared to the number of detections at the middle and north bank sites (4 each), combined 
with the larger estimated values for the south bank site indicate that Missouri River water quality on the south side of the river probably was only moderately influenced by the south bank inflows to the river just upstream from the Independence well field.

Dissolved oxygen, specific conductance, temperature, and turbidity were measured at 4,280 locations in the Missouri River just upstream from and adjacent to the Independence well field. The smaller dissolved oxygen concentrations along the south bank may have been caused by larger amounts of organic material supplied by south bank inflows from the sewage-treatment plants. In contrast to dissolved oxygen in the Missouri River, specific conductance remained largest along the south bank of the river. This most likely occurred because high flow velocity in the center of the channel prevented south bank inflows from mixing across the channel in the Missouri River. Areas of relatively high specific conductance are located at the outfalls from the sewage-treatment plants, the mouth of the Blue River, along the south bank of the Missouri River, and the former oil refinery indicating these inflows to the river may be at least moderately affecting the spatial distribution of riverwater quality near the well field. The distribution of water temperature and turbidity did not seem to be affected by local inflows to the Missouri River in this reach.

Results from this study indicate riverbank filtration generally decreased the concentration of most water-quality constituents as water traveled between the Missouri River and wells of the city of Independence, Missouri, well field.

The conclusions from this study are:

- Median values of almost all constituents decreased as water traveled between the Missouri River, wells 7 and 38 , and collector well 41 of the Independence well field.

- Approximate ground-water traveltimes from the river to the wells, based on water temperature profiles, are less than rates typical of slow sand filters, and indicate riverbank filtration at this site may be comparable to or more effective than a slow sand filter.

- Water-quality changes between samples from the Missouri River and samples collected from wells at times that approximated the traveltime from the Missouri River to wells indicate no clear relation between changes in water quality in the Missouri River and in wells for almost all constituents. The absence of any trends in water quality between the Missouri River and the pumping wells indicates the strong influence of riverbank filtration.

- Total coliform bacteria, Cryptosporidium, Giardia, and total culturable viruses were detected in samples from the Missouri River, but were undetected in all samples from wells indicating effective removal of these organisms by riverbank filtration.

- Haloacetic acid formation potential changes in water samples from the Missouri River were related to changes of dissolved organic carbon (DOC), ultraviolet absorption at 254 nanometers (UV254), ultraviolet absorption UV254 divided by the dissolved organic carbon concentration and multiplied by 100 (SUVA), tannin and lignin, and turbidity. Trihalomethane formation potential changes in water samples from the Missouri River were related to DOC, UV254, tannin and lignin, and turbidity. These surrogate constituents and properties likely would be good indicators of haloacetic acid and trihalomethane formation potentials in water from the Missouri River. Haloacetic acid and trihalomethane formation potentials were not related to any of these constituents or properties in water samples from wells.

- Results of analyses for organic wastewater compounds and the distribution of dissolved oxygen, specific conductance, and temperature indicate that Missouri River water quality on the south side of the river probably was moderately influenced by the south bank inflows to the river just upstream from the Independence well field.

\section{References}

Brenton, R.W., and Arnett, T.L., 1993, Methods of analysis by the U.S. Geological Survey National Water Quality Laboratory-Determination of dissolved organic carbon by uv-promoted persulfate oxidation and infrared spectrometry: U.S. Geological Survey Open-File Report 92-480, 12 p.

Britton, L.J., and Greeson, P.E., eds., 1987, Methods for collection and analysis of aquatic biological and microbiological samples: U.S. Geological Survey Techniques of WaterResources Investigations, book 5, chap. A4, p. 223-225

Camp, Dresser, and McKee, Inc., December 2000, City of Independence, Missouri Water Department, Comprehensive Master Plan, Water Supply, Treatment and Distribution System Facilities: Kansas City, Missouri.

DiGiorgio, C.L., Gonzalez, D.A., and Huitt, C.C., 2002, Cryptosporidium and Giardia Recoveries in Natural Waters by Using Environmental Protection Agency Method 1623: Applied and Environmental Microbiology, v. 68, no. 12, p. 5,952-5,955.

Fishman, M.J., 1993, Methods of analysis by the U.S. Geological Survey National Water Quality Laboratory-Determination of inorganic and organic constituents in water and fluvial sediments: U.S. Geological Survey Open-File Report 93$125,217 \mathrm{p}$.

Fishman, M.J., and Friedman, L.C., 1989, Methods for determination of inorganic substances in water and fluvial sediments: U.S. Geological Survey Techniques of WaterResources Investigations, book 5, chap. A1, 545 p.

Helsel, D.R., and Hirsch, R.M., 1992, Statistical methods in water resources: U.S. Geological Survey Techniques of Water Resources Investigations, book 4, chap. A3, 450 p. 
Hunt, R.J., Coplen, T.B., Haas, N.L., Saad, D.A., and Borchardt, M.A., 2005, Investigating surface water-well interaction using stable isotope ratios of water: Journal of Hydrology, v. 302, no. 1-4, p. 154-172.

Kelly, B.P., 1996, Simulation of ground-water flow and contributing recharge areas in the Missouri River alluvial aquifer at Kansas City, Missouri and Kansas: U.S. Geological Survey Water-Resources Investigations Report 96-4250, $93 \mathrm{p}$.

2002, Ground-water flow simulation and chemical and isotopic mixing equation analysis to determine the contribution of the Missouri River to the city of Independence, Missouri well field: U.S. Geological Survey Water-Resources Investigations Report 02-4208, 53 p.

Kelly, B.P., and Blevins, D.W., 1995, Vertical hydraulic conductivity of soil and potentiometric surface of the Missouri River alluvial aquifer at Kansas City, Missouri and Kansas-August 1992 and January 1993: U.S. Geological Survey Open-File Report 95-322, 19 p.

Missouri Department of Natural Resources, 2003, Code of State Regulations, Contaminant levels and monitoring: Jefferson City, Public Drinking Water Program, 31 p.

Nikolaou, A.D., Kostopoulou, M.N., and Lekkas, T.D., 1999, Organic by-products of drinking water chlorination: Global Nest: The International Journal. v. 1, no. 3, p. 143-156.

Standard Methods for the Examination of Water and Wastewater, 20th edition, 1998: American Public Health Association, 1015 Fifteenth Street, NW, Washington, DC 20005.

Stonestrom, D.A., and Constanz, J., ed., 2003, Heat as a tool for studying the movement of ground water near streams: U.S. Geological Survey Circular 1260, 96 p.

U.S. Environmental Protection Agency, 1995a, Haloacetic acids and dalapon by liquid-liquid extraction, derivatization and GC with electron capture detector, publication no. EPA/ 600/R-95-131. Government Printing Office, Washington, D.C.

1995b, Purgeable organic compounds by capillary column GC/Mass spectrometry, publication no. EPA/600/R95-131. Government Printing Office, Washington, D.C. 1996, ICR microbial laboratory manual: publication EPA/600/R-95/178. Government Printing Office, Washington, D.C.

2001, Cryptosporidium and Giardia in water by filtration/IMS/FA: publication EPA/821/R-01/025. Government Printing Office, Washington, D.C., 52 p.

2005, Surf Your Watershed: accessed October 2005, at URL http://www.epa.gov/surf.

U.S. Geological Survey, National field manual for the collection of water-quality data: U.S. Geological Survey Techniques of Water-Resources Investigations, book 9, chaps. A1-A9, 2 v., variously paged. [Chapters were published from 1997-2004; updates and revisions are ongoing and can be viewed at: http://water.usgs.gov/owq/FieldManual/mastererrata.html].

Wagner, R.J., Mattraw, H.C., Ritz, G.F., and Smith, B.A., 2000, Guidelines and standard procedures for continuous water- quality monitors - Site selection, field operations, calibration, record computation, and reporting: U.S. Geological Survey Water-Resources Investigation Report 00-4252, $53 \mathrm{p}$.

Wang, J.Z., Hubbs, S.A., and Song, R., 2002, Evaluation of riverbank filtration as a drinking water treatment process: Denver, Colorado, American Water Works Research Foundation, $145 \mathrm{p}$.

Zaugg, S.D., Smith, S.G., Schroeder, M.P., Barber, L.B., and Burkhardt, M.R., 2002, Methods of analysis by the U.S. Geological Survey National Water Quality Laboratory-Determination of wastewater compounds by polystyrene-divinylbenzene solid-phase extraction and capillary-column gas chromatography/mass spectrometry: U.S. Geological Survey Water-Resources Investigations Report 01-4186, 37 p. 